\title{
Atomic Layer Deposition of stable 2D materials
}

\author{
W. Hao, C. Marichy*, C. Journet \\ Univ Lyon, Université Claude Bernard Lyon 1, CNRS, Laboratoire des Multimatériaux et Interfaces, F- \\ 69622 Villeurbanne, France
}

*Corresponding author: catherine.marichy@univ-lyon1.fr

\begin{abstract}
Following the graphene isolation, strong interest in two dimensional (2D) materials has been driven by their outstanding properties. Their typical intrinsic structure, including strong in-plane covalent bonding and weak out-of-plane Van der Waals interaction, makes them highly promising in diverse areas such as electronics, catalysis, and environment. Growth of 2D materials requires a synthesis approach able to control the deposition onto a support at the atomic scale. Thanks to their simplicity, versatility and ability to control thickness at the angstrom level, Atomic Layer Deposition (ALD) and its variant Atomic Layer Etching (ALET) appear as ones of the most suited techniques to synthesize 2D materials. The development of ALD technique for fabricating 2D materials in the last ten years justifies reviewing its most recent groundbreaking discoveries and progresses. Particular attention will be paid to stable 2D materials especially graphene, $\mathrm{h}-\mathrm{BN}$, Mo and $\mathrm{W}$ dichalcogenides and few monolayered metal oxides. Specificities and outputs of ALD for 2D material as well as emerging directions and remaining technical challenges will be highlighted.
\end{abstract}

\section{Introduction}

Since the first graphene exfoliation in $2004^{1}$, two-dimensional (2D) material has arisen as new outstanding nanostructure family. Beyond graphene, stable 2D structures like hexagonal boron nitride (h-BN), Transition Metal Dichalcogenides (TMDs) $M X_{2}$ (with $M=M o$ or $W$ and $X=S$, Se or Te) and oxides can be found. ${ }^{2,3}$ They all display layered crystalline structure in which the atomic planes are linked together by Van der Waals ( $\mathrm{ddW}$ ) forces and so can easily be exfoliated into one or more layers. This kind of materials exhibits interesting properties related to their size restriction: electronic confinement, modifying both optical and electronic properties, and high surface to volume ratio that affects the mechanical and chemical properties. ${ }^{4,5}$ Therefore, 2D materials are highly attractive due to their potential in cutting edge domains such as micro-, and opto-electronics ${ }^{4,6}$ as well as renewable energy, ${ }^{4,7-9}$ catalysis, $^{10,11}$ gas sensing ${ }^{12,13}$ and environment. ${ }^{4,7,14,15}$ They are also exciting because of their possibility to be stacked into VdW heterostructures combining and/or tuning their 
chemical and physical properties. ${ }^{6,16-18}$ However, since 2D materials are atomically thin, a suitable manufacturing process capable of controlling their fabrication in terms of structure, composition, thickness, defects, purity and crystallinity without degradation of their original properties is necessary. Two approaches can be considered: the top-down and bottom-up synthetic routes. ${ }^{19}$

Historically, top-down approach has first been developed using mechanical and chemical exfoliation techniques, ${ }^{1,2,20,21}$ the first example being the well-known graphene exfoliation using scotch tape. Later on, etching processes have been adapted. Recently, Atomic Layer Etching (ALET), ${ }^{22}$ the top down variant of Atomic Layer Deposition (ALD), has been introduced for fabricating 2D materials. On the other hand, bottom-up techniques have largely been developed using conventional thin film deposition. These techniques include sputtering, evaporation and Chemical Vapor Deposition (CVD). ${ }^{3,23,24}$ However, they are mainly based on either high temperature processes, substrate restrictive deposition or low thickness control. ${ }^{21,25,26}$ Amongst all the fabrication processes, ALD appears to be one of the most suited techniques to synthesize 2D materials, because of its simplicity, versatility and control of the thickness at the angstrom level. ${ }^{27-29}$

Based on self-terminated surface reactions, the precursors are kept separated and react only with surface species in a self-limiting process, forming at most one single atomic layer per cycle. No reaction in gas phase occurs, differentiating the ALD to the CVD. Each surface reaction is separated by a purge step to remove the unreacted precursor and the by-product. The sequence of reactant surface reactions and purges constitutes a cycle. Due to the self-limiting character of the ALD reactions, the thickness of the as-deposited film is simply controlled by the number of cycles with precision at the angstrom level. ${ }^{27,28}$ ALD processes exist for a large variety of materials ranging from pure elements to metal oxides, chalcogenides, nitrides, carbides, sulfides and phosphates. ${ }^{30,31}$ Thanks to its atomic control of the layer thickness, ALD has been successfully applied to the deposition of $2 D$ materials. ${ }^{29}$ Recently, a variant approach called Atomic Layer Etching has been reported for obtaining well-defined graphene monolayer, for instance. ${ }^{32}$ ALET is based on self-limiting layer etching and allows removal layer by layer of a material. It can be seen as inverse (or top-down) ALD process. ${ }^{22}$

Recent reviews deal with ALD of sulfides and dichalcogenides. ${ }^{33-37}$ However, the important number of studies reporting the use of ALD for the fabrication of $2 \mathrm{D}$ materials published in the last few years and the absence of focus on the most known 2D materials justify reviewing the recent advances in the field. The family of $2 \mathrm{D}$ materials being constituted of stable, probably stable and unstable materials under ambient conditions, some of them remain only hypothetical. ${ }^{4,5,17,38,39}$ For the sake of clarity, the present review aims at summarizing the most significant progresses related to ALD and ALET fabrication of stable 2D materials reported since the graphene isolation in 2004. After reporting 
progresses in fabrication of graphene and graphene like materials ( $h-B N)$, stable dichalcogenides $\left(M X_{2}\right.$ with $M=M o, W$ and $\left.X=S, S e, T e\right)$ will be presented followed by recent advances in $2 D$ metal oxide, mostly $\mathrm{MoO}_{3}$ and $\mathrm{WO}_{3}$. The involved chemistry, growth issue and remaining challenges will be discussed. Probably stable in inert atmosphere chalcogenide 2D materials will be briefly reviewed even though slightly out the scope of the paper. Regarding this aspect, the reader can refer to the recent reviews mentioned above.

\section{Graphene family: graphene and h-BN}

Since the first exfoliation of graphene, ${ }^{1}$ graphene and graphene-like materials, ${ }^{40,41}$ such as black phosphorous and hexagonal boron nitride ( $\mathrm{h}-\mathrm{BN}$ ) have attracted great attention from the scientific community. Regarding the stability of these materials as well as the availability of precursors, only graphene and h-BN have been successfully synthesized by ALD and ALET up to now. The following part aims to review the current state of the art on graphene family fabrication by atomic layer techniques and to emphasize the related challenges in term of chemistry. The various fabrication strategies employed are summarized in Table 1.

\subsection{Fabrication of graphene}

Tremendous works have been done on fabricating ultrathin and defect-free graphene in the past few years. ${ }^{42-44} \mathrm{CVD}$ is the most used technique for its growth which is mainly realized on metal foils ( $\mathrm{Cu}$, $\mathrm{Ni})$ and often requires high temperature $\left(>800{ }^{\circ} \mathrm{C}\right) .{ }^{44}$ Even though single layer graphene can be obtained by CVD, the number of graphene sheets remains difficult to control. Therefore, ALD technique seems a method of choice to deposit graphene as it allows a control of the thickness at the atomic scale and it needs lower deposition temperature $\left(<600^{\circ} \mathrm{C}\right)$. The first and only work on ALD of graphene, published in 2014 by Zhang et al. ${ }^{45}$ reports Remote Plasma-Enhanced ALD (PEALD) using sequential pulses of benzene and $\mathrm{H}_{2} / \mathrm{Ar}$. High-quality graphene sheets are successfully obtained on $\mathrm{Cu}$ foils at $400{ }^{\circ} \mathrm{C}$ in a controllable growth manner. After reduction of the copper substrate, $10 \mathrm{ALD}$ cycles at $400{ }^{\circ} \mathrm{C}$ permit obtaining monolayered graphene (Figure 1a). Further increase of the cycle number leads to multiple layers. Characterization by Transmission Electron Microscopy (TEM), after transfer to TEM grid, reveals absence of contaminants as well as good crystallinity (Figure 1b). Raman spectroscopy (Figure 1c) displays two sharp bands that correspond to the $G$ and 2D bands, with a $2 \mathrm{D} / \mathrm{G}$ ratio of about 1.7 confirming deposition of a single layer. 

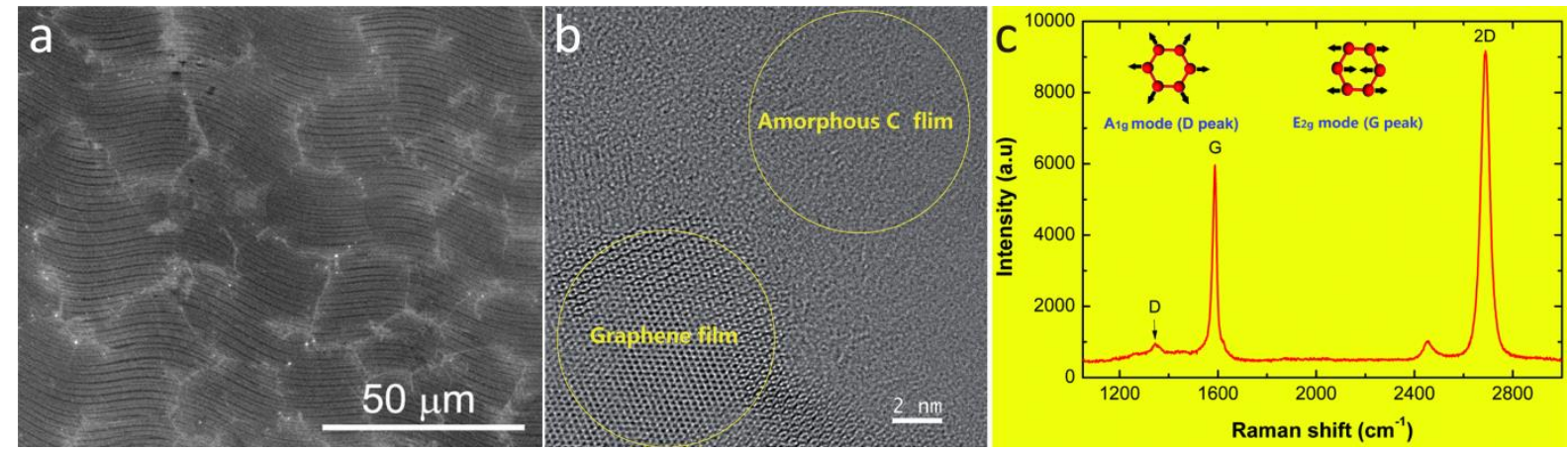

Figure 1 a) Scanning Electron Microscopy (SEM) image of the graphene sheet grown after 10 ALD cycles at $400{ }^{\circ} \mathrm{C}$. b) HighResolution TEM (HRTEM) image of graphene on amorphous carbon TEM grid. c) Raman spectrum of the graphene grown after $10 \mathrm{ALD}$ cycles and transferred on a $300 \mathrm{~nm}$-thick $\mathrm{SiO}_{2} / \mathrm{Si}$ substrate. Reproduced with permission from ref. ${ }^{45}$

On the other hand, ALET, the top-down variant of ALD, is reported in the literature for fabricating graphene from few layers of graphite. ${ }^{32,46,47}$ In 2011, Dimiev et al..$^{32}$ demonstrate for the first time a layer-by-layer removal of graphene sheets. At the opposite of other etching processes, like ion beam or electron lithography, ${ }^{48,49}$ the reported experiment allows a precise thinning by successive cycles made of local zinc sputtering and liquid $\mathrm{HCl}$ etching steps. This process can be regarded as an ALET method as each $\mathrm{Zn} / \mathrm{HCl}$ etching cycle is self-limited and removes one single layer. Zinc is locally deposited on graphene assuring etching on specific areas. The mechanism of the removal process is explained by the production on the top layer of homogeneously dispersed defects, mainly carbonyl and oxygen groups. The damaged carbon layer is removed with the $\mathrm{HCl}$ treatment leaving the underneath carbon layer without any damage or defect. It turns out that use of metal sputtering is the key point as no etching is observed when thermal evaporation is used as it does not create such defects. Different couples than $\mathrm{Zn} / \mathrm{HCl}$ of metal/etching solution can be used like $\mathrm{Al} / \mathrm{NaOH}$, $\mathrm{Cu} / \mathrm{HCl} / \mathrm{CuCl}_{2}$ and $\mathrm{Au} / \mathrm{KI} / \mathrm{I}_{2}$ even though they are less effective. This method is efficient for etching different carbon based materials: graphene oxide (GO), chemically converted-, CVD deposited- and micromechanically exfoliated-graphene. It also reveals highly suited for patterning such materials, which permits an easy determination of the thickness and number of removed layers using Atomic Force Microscopy (AFM). For instance, one etching cycle, when locally applied to two transferred layers of graphene, leads to a pattern alternating stripes of bi- and mono- graphene layers. These structures are integrated into an electrical device and their properties are investigated. It can be noted that the etching resolution in width of $\mathrm{Zn} / \mathrm{HCl}$ process is $100 \mathrm{~nm}$.

In 2011 and 2012, the group of Yeom ${ }^{46,47}$ reports a four-step neutral beam assisted ALET on exfoliated Highly Oriented Pyrolytic Graphite (HOPG) transferred to $\mathrm{SiO}_{2}$ substrate for the fabrication of graphene devices. The process consists in: (step 1 ) adsorption of $\mathrm{O}_{2}$ radicals produced by Inductively Coupled Plasma (ICP) on the graphene surface, (step 2) removal of remaining $\mathrm{O}_{2}$ radicals, 
(step 3) desorption of chemisorbed C-O bonding layers by high energy Ar beam irradiation and (step 4) elimination of remaining Ar and chemisorbed species. Removal of a single layer per etching cycle is confirmed using X-ray Photoelectron Spectroscopy (XPS), optical microscopy and Raman spectroscopy. Adsorption of $\mathrm{O}_{2}$ radical leads to formation of $\mathrm{C}-\mathrm{O}$ bonds and thus to modification from $\mathrm{sp}^{2}$ to $\mathrm{sp}^{3}$ carbon bonds that in turn reduces the percentage of $\mathrm{sp}^{2} \mathrm{C}-\mathrm{C} .{ }^{46}$ Being very stable, graphene surface is only affected by $\mathrm{O}_{2}$ radicals and not by oxygen molecules $\left(\mathrm{O}_{2}\right.$ gas $) .{ }^{47}$ The created $\mathrm{C}-\mathrm{O}$ species on top of the graphene are completely removed by the Ar beam irradiation while the underneath $\mathrm{sp}^{2} \mathrm{C}-\mathrm{C}$ bonding remains unchanged. It should be pointed out that damage of the carbon layer, caused by bombardment with high energy beam during the desorption step and the assistance of the neutral beam, occurs during ALET. Damages of the graphene surface are confirmed by XPS that shows an increase of $\mathrm{sp}^{3}$ bonding content as well as by Raman spectroscopy exhibiting $\mathrm{D}$ band associated to a decrease of the $2 \mathrm{D}$ one. The graphene surface can mostly be recovered by post annealing treatment under $\mathrm{H}_{2} / \mathrm{He}$, even though the lack of carbon at the surface does not fulfill the recrystallization process. ${ }^{46,47}$ Using this layer-by-layer etching method, controlled graphene based Field Effect Transistors (FET) are fabricated using masking on a superposition of three transferred CVD layers of graphene onto $\mathrm{SiO}_{2} / \mathrm{Si}$. Local patterned domains with bi-, single- or zero- layer graphene are successfully achieved controlling the number of cycles (Figure 2a,b). Weak electrical characteristics are observed for the fabricated graphene FET. This is partially related to damages of graphene during ALET, to CVD graphene quality, and to the $A B$ stacking mismatch of transferred monolayers. $^{47}$

Therefore, later on, the ALET parameters, such as ion energy, fluxes and exposure time, are optimized to avoid creating additional defects. ${ }^{50}$ Use of lower energy oxygen $\left(\mathrm{O}_{2}{ }^{+} / \mathrm{O}^{+}\right)$and $\mathrm{Ar}^{+}$ions during, respectively, the adsorption and desorption steps, and longer desorption time permits precise etching of one full single graphene layer without any damage (Figure $\mathbf{2 c}$ ). Removal of exactly one single layer is verified by applying the process to a bilayer graphene and then measuring the sample thickness and roughness before and after ALET (Figure 2d,e). 

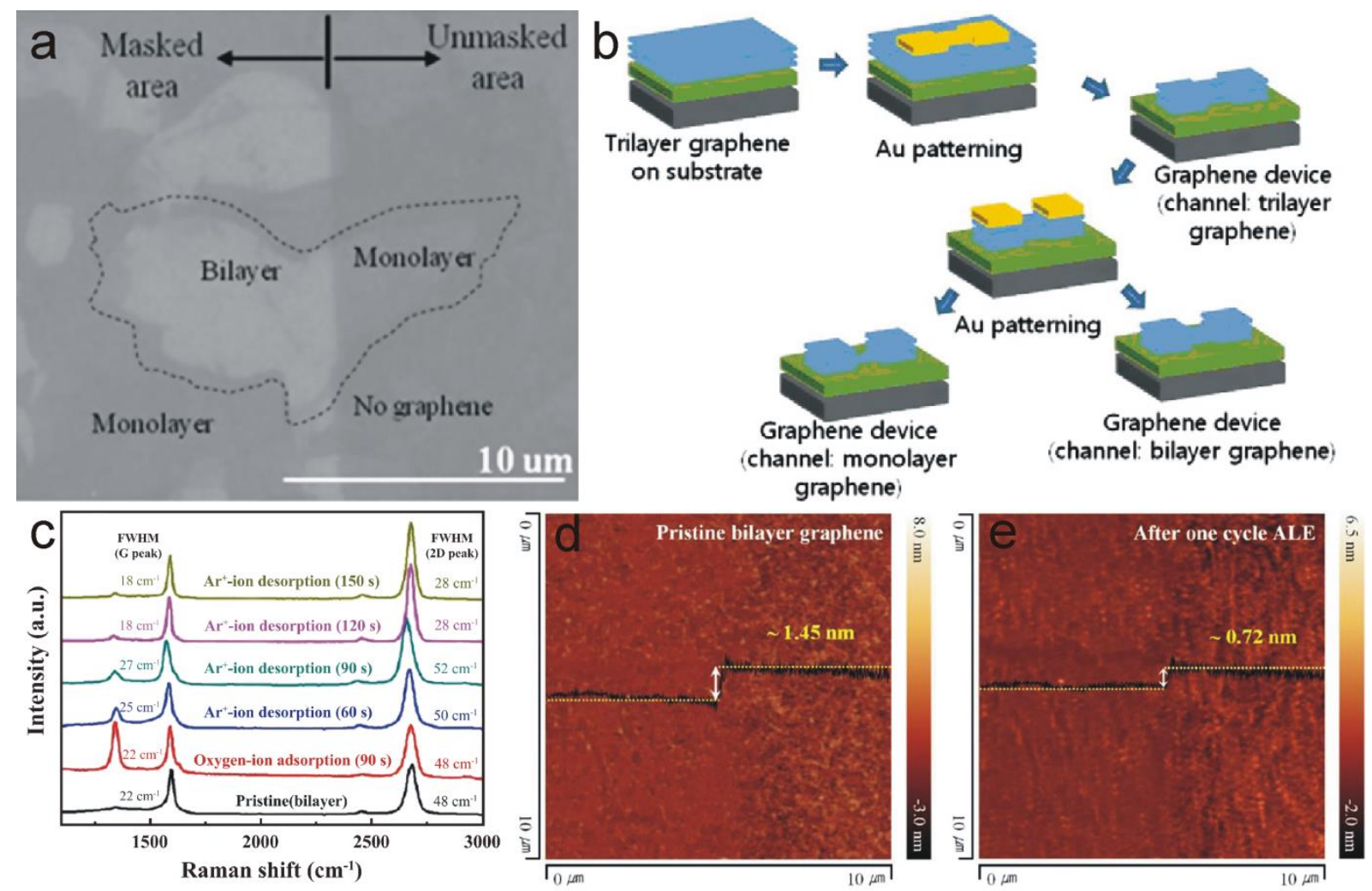

Figure 2 a) SEM image of a patterned bilayer graphene sheet after one ALET cycle. b) Fabrication steps of a full graphene FET device. Reproduced with permission from ref. ${ }^{47}$ c) Raman spectra of bilayer graphene after each ALET step as function of the $\mathrm{Ar}^{+}$-ion desorption time. AFM images before d) and after e) one ALET cycle performed on bilayer graphene. Reproduced with permission from ref. ${ }^{50}$

On one hand, ALD synthesis of few- or mono-layers graphene has already been demonstrated. However, several challenges still need to be addressed such as obtaining wafer scale single domain, homogeneity over large area and accurate control of the number of deposited layers. Although only one work is reported in the literature up to now, graphene ALD can be a good alternative to conventional CVD techniques. Nonetheless, finding suitable precursors and growth limitation related to the inertness of the basal planes are important challenges that still need to be addressed.

On the other hand, ALET has succeeded in obtaining controlled number of layers from transferred graphene and recent progresses lead to near defect-free surface. This approach allows the layer-bylayer removal of graphene and has demonstrated to be very powerful when combined to patterning techniques for electronic device fabrication. Currently, resolution in width of $100 \mathrm{~nm}$ is reached which is very promising for the next generation of nanoelectronic devices based on 2D materials.

\subsection{Fabrication of BN}

Hexagonal boron nitride, an isostructural to graphene, also called "white graphite", is an insulator with a wide direct band gap of around $6.0 \mathrm{eV} .^{51,52}$ It displays high thermal and chemical stability, high 
thermal conductivity, low density, and high oxidation resistance, ${ }^{53}$ making it an ideal smooth substrate for 2D electronic devices, ${ }^{54}$ especially for graphene based devices. ${ }^{55}$ Several methods have been reported to prepare h-BN thin films such as mechanical cleavage, ${ }^{56}$ liquid exfoliation $^{57}$ and CVD. ${ }^{51,52}$ Nevertheless, wafer scale, high quality, ultra-thin, conformal and uniform h-BN layers directly on wide range of substrates with a controlled thickness still remain very challenging. These limitations might be addressed using ALD. Several works on ALD and sequential CVD of BN have been published since the last fifteen years. ${ }^{53,58-76}$ However, the crystalline quality, due to the mild growth temperature used, still needs improvement and post annealing is usually employed. The different ALD strategies for BN (Table 1) will be discussed according to the type of boron precursor.

\subsubsection{Boron halide}

In early 2000's, Density Functional Theory (DFT) has demonstrated the encouraging combination of $\mathrm{NH}_{3}$ and $\mathrm{BBr}_{3}$ for ALD growth of cubic BN. ${ }^{77}$ The same year, BN films onto silica substrates are ALD synthesized, at 400 and $750{ }^{\circ} \mathrm{C}$, from these two reactants. ${ }^{58}$ Films deposited at $400{ }^{\circ} \mathrm{C}$ are significantly less ordered and stable than that at $750{ }^{\circ} \mathrm{C}$, which present a turbostratic structure. The obtained $\mathrm{BN}$ films are transparent, very smooth (with surface roughness range of 0.3-0.5 nm) and nearstoichiometric ( $\mathrm{B}: \mathrm{N} \approx 0.95)$, whatever the deposition temperature. In 2005 , Olander et al. ${ }^{68}$ report Laser-Assisted ALD (LALD) using the same precursors at a temperature range of $250-750{ }^{\circ} \mathrm{C}$. ArF excimer laser irradiation during each precursor pulses provokes dissociation of both $\mathrm{BBr}_{3}$ and $\mathrm{NH}_{3}$ as evidenced by optical emission spectroscopy. This dissociation consists in a crucial step as different $\mathrm{BBr}_{\mathrm{x}}$ and $\mathrm{NH}_{\mathrm{x}}$ (with $\mathrm{X}=0-3$ ) highly active species are produced. Supported by DFT calculations, the key role of $\mathrm{BBr}_{3}$ activation, which creates $\mathrm{B}$ radicals that preferentially adsorb on $\mathrm{N}$-edges of the deposited film, is demonstrated. Activated $\mathrm{BBr}_{3}$ alone is insufficient to grow BN film; $\mathrm{NH}_{3}$ is mandatory even though its activation is not required. The laser assistance improves the growth per cycle (GPC) by $100 \%$ compared to conventional thermal ALD between 250 and $600{ }^{\circ} \mathrm{C}$, while a decrease is observed above $600{ }^{\circ} \mathrm{C}$ due to species desorption. On the other hand, below $600{ }^{\circ} \mathrm{C}$, the films appear unstable in air despite a turbostratic phase formation. The surface roughness of the obtained films tends to increase with deposition temperature and it is even more noticeable in LALD than with conventional thermal ALD.

Recently, Weber et al. ${ }^{62}$ report thermal ALD growth of $\mathrm{BN}$ nanoporous membranes from $\mathrm{BBr}_{3}$ and $\mathrm{NH}_{3}$ using anodic aluminum oxide (AAO) as template. Turbostratic $\mathrm{BN}(\mathrm{t}-\mathrm{BN})$ thin films are successfully deposited with a GPC of $0.08 \mathrm{~nm} / \mathrm{cycle}$ and the diameter of the nanopores can easily be tuned according to the deposited thickness. The ionic transport properties of such BN nanopores are investigated and reveal promising for ionic separation and ultrafiltration devices. The mechanical 
properties of $\mathrm{BN}$ film onto $\mathrm{Si}(100)$ are also studied by nanoindentation. Post annealing treatment at $1350{ }^{\circ} \mathrm{C}$ improves by $37 \%$ the elastic modulus compared to film grown at $750{ }^{\circ} \mathrm{C}$, without impacting the hardness. ${ }^{78}$

Compare to $\mathrm{BBr}_{3}, \mathrm{BCl}_{3}$ is less thermodynamically reactive because the Lewis acid strength of $\mathrm{BBr}_{3}$ is higher than that of $\mathrm{BCl}_{3}$. Simultaneously as the development of $\mathrm{BBr}_{3}$ based $\mathrm{ALD},{ }^{58}$ Ferguson et al. ${ }^{59}$ report the ALD deposition of $\mathrm{BN}$ onto $\mathrm{ZrO}_{2}$ particles using $\mathrm{BCl}_{3}$ and $\mathrm{NH}_{3}$ at $500 \mathrm{~K}$, with a $\mathrm{GPC}$ of approximately $0.1 \mathrm{~nm} /$ cycle. In-situ transmission Fourier Transform Infra-Red (FTIR) spectroscopy monitoring, performed on 26 ALD cycles, reveals that $\mathrm{BCl}_{3}$ first reacts with the available $\mathrm{ZrOH}^{*}$ groups to create $\mathrm{ZrOBCl}_{2}{ }^{*}$ surface species that, with the following $\mathrm{NH}_{3}$ pulse, will form $\mathrm{BNH}_{2}{ }^{*}$ and $\mathrm{B}_{2} \mathrm{NH}^{*}$ hydrides at the surface under the removal of $\mathrm{HCl}$. During the subsequent $\mathrm{BCl}_{3}$ exposure, $\mathrm{BNH}_{2}{ }^{*}$ surface groups are completely removed under $\mathrm{HCl}$ release, while only a fraction of $\mathrm{B}_{2} \mathrm{NH}^{*}$ species reacts leading to gradual accumulation into the growing film. The residual monohydrides can be removed by thermal annealing above $1100 \mathrm{~K}$. This process also permits BN coating onto metal powders to improve their tribological properties. ${ }^{60}$ Later on, this chlorine ALD process has been used to design electronic devices such as metal-insulator varistors (MIVs) ${ }^{72}$ or graphene based FET. ${ }^{65,61}$ In particular, Bjelkevig et al. ${ }^{65}$ report deposition of h-BN monolayer on Ru(0001) after 2 ALD cycles at $550 \mathrm{~K}$ followed by an Ultra-High Vacuum (UHV) annealing at $1000 \mathrm{~K}$. Low Energy Electron Diffraction (LEED) image recorded from h-BN/Ru(0001) displays sharp and well-defined six-fold spots characteristic of good h-BN crystalline quality. The fabricated $\mathrm{h}-\mathrm{BN} / \mathrm{Ru}(0001)$ is subsequently used as substrate for graphene CVD. Strong h-BN/graphene coupling and charge transfer from h-BN monolayer to graphene $\pi^{*}$ band are evidenced by the red-shifts of the Raman $G$ and 2D bands compared to reference HOPG. This strong electronic interaction, without perturbing the intrinsic graphene electronic structure, arises from the direct growth of graphene on h-BN/Ru(0001) substrate, which drastically differs from transferred graphene on $\mathrm{SiO}_{2}$, graphene/SiC substrate or single and few layers graphene directly grown on $\mathrm{Ru}(0001)$. Tuning the nature of the substrate as well as controlling the number of $\mathrm{h}-\mathrm{BN}$ underlayers might permit adjusting the interactions between graphene and h-BN. Therefore, bilayer and trilayer h-BN(0001) films are deposited onto Co(0001) without evidence of Co oxidation, promising for applications in spintronics and graphene electronics. ${ }^{79}$ Recently, multilayer azimuthally oriented h-BN thin films showing highly ordered large areas and domains (up to $20 \mu \mathrm{m}$ ) are uniformly and continuously deposited on Co(0001) by ALD followed by UHV annealing, as demonstrated by cross-section HRTEM (Figure 3a). ${ }^{61}$ Then, graphene is grown on pinhole-free h-BN/Co(0001) using Molecular Beam Epitaxy (MBE) as shown in Figure $\mathbf{3 b}$. XPS characterization, in addition to absence of oxidation, evidences no strong interfacial charge transfer or covalent bonding between Co and h-BN. Therefore, metal substrates like $\mathrm{Ru}(0001)$ and Co(0001) strongly influence the growth and orbital hybridization of h-BN layers. Various substrates, 
such as Si-terminated $\mathrm{CoSi}_{2}(111) / \mathrm{Si}(111), \mathrm{Ru}(0001),{ }^{80} \mathrm{RuO}_{2}(100) / \mathrm{Ru}(0001)^{81}$ are investigated for fabricating graphene based transistors. ${ }^{80}$ For instance, monolayer and multiple layers $\mathrm{h}-\mathrm{BN}(0001)$ are grown on single layer $\mathrm{RuO}_{2}(100) / \mathrm{Ru}(0001)$ to cut off the orbital hybridization that occurs at the $\mathrm{BN} / \mathrm{Ru}$ interface. Although the oxide layer inhibits the electronic interaction between $\mathrm{h}-\mathrm{BN}$ and $\mathrm{Ru}(0001)$, epitaxial relationship between $\mathrm{h}-\mathrm{BN}$ and the metal is still observed with $30^{\circ}$ rotation between the $\mathrm{h}-\mathrm{BN}$ and $\mathrm{RuO}_{2}(100)$ planes. ${ }^{81}$ Such lattice matching paves the way to $\mathrm{BN}$ and/or graphene on $\mathrm{RuO}_{2}(110) / \mathrm{Co}$ or $\mathrm{RuO}_{2}(110) / \mathrm{Ni}$ fabrication.

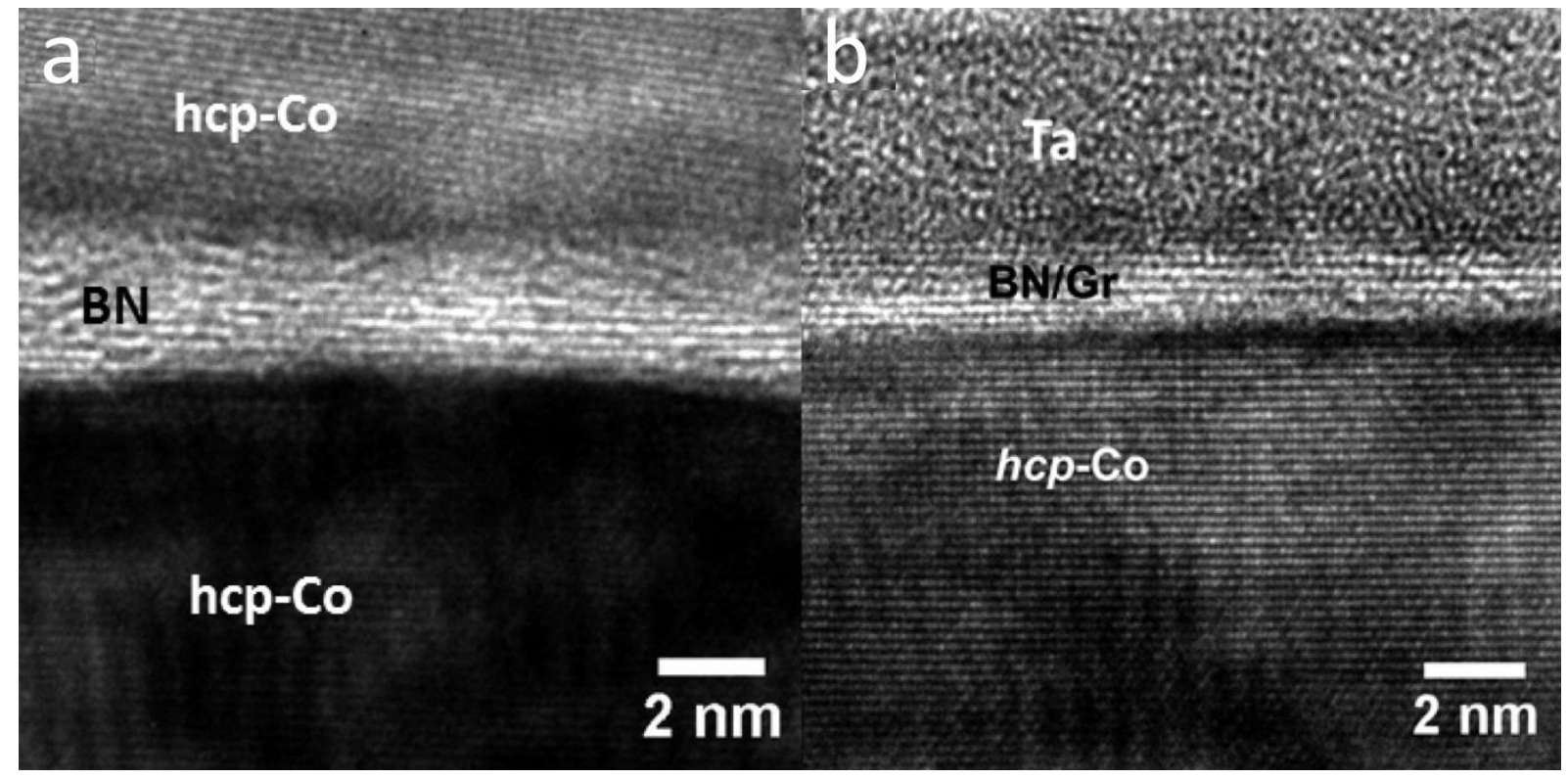

Figure 3. a) HRTEM image of Co/BN/Co interface on sapphire substrate. b) HRTEM image of Co/BN/Graphene/Ta interface that does not display contrast between graphene and h-BN layers. Reproduced with permission from ref. ${ }^{61}$

Reactions of boron halides with $\mathrm{NH}_{3}$ have been early investigated despite they are oxygen- and moisture-sensitive as well as difficult to handle and might release corrosive by-product ( $\mathrm{HX}$ with $\mathrm{X}=\mathrm{Cl}$, $\mathrm{Br}$ ). Poor crystallinity is observed for the as-deposited film, while 2D layers that might be even epitaxial to the substrate are formed under UHV high temperature post-annealing (800-1000 K). Although it has not been mentioned above, it should be pointed out that halide impurities, which might be removed by thermal treatment, can remain into the as-grown film. ${ }^{79,81}$ To overcome halide related-drawbacks, different strategies are envisaged. On the one hand, Wolf et al. ${ }^{82,83}$ use anhydrous hydrazine $\left(\mathrm{N}_{2} \mathrm{H}_{4}\right)$ as alternative nitrogen source. In particular, amorphous BN is deposited on $\mathrm{Si}_{0.7} \mathrm{Ge}_{0.3}(100), \mathrm{Cu}$, and HOPG from sequential exposures of $\mathrm{N}_{2} \mathrm{H}_{4}$ and $\mathrm{BCl}_{3}$ at $350{ }^{\circ} \mathrm{C}^{83} \mathrm{~N}_{2} \mathrm{H}_{4}$ source prevents generation of halide contaminant into the films and decreases the growth temperature. On the other hand, reactions with other boron precursors like boranes or organoborons are explored as well as PEALD. 


\subsubsection{Boranes and organoborons}

Ismach et al. ${ }^{74}$ compare reaction of diborane with $\mathrm{NH}_{3}$ on Ni substrate at $1025{ }^{\circ} \mathrm{C}$ under conventional CVD and sequential growth, i.e. successive introduction of precursors. The stoichiometry (1:1) of the deposited material reveals to be independent on the fabrication mode. However, without affecting the final number of h-BN layers (Figure $4 \mathbf{a}, \mathbf{b}$ ), the order of the reactant pulses in sequential CVD impacts the $\mathrm{h}-\mathrm{BN} / \mathrm{Ni}$ interface. When $\mathrm{NH}_{3}$ is first pulsed, only $\mathrm{B}-\mathrm{N}$ bonds are formed while formation of B-N, B-O and B-Ni bonds caused by B precursor decomposition (starting from $800^{\circ} \mathrm{C}$ ) is noted with diborane (Figure $\mathbf{4 c , d}$ ). Using a tungsten filament to $\mathrm{crack}^{\mathrm{NH}} \mathrm{N}_{3}$, Kovalgin et al. ${ }^{75}$ report a Hot-Wire assisted ALD (HWALD) approach to grow $\mathrm{B}_{\mathrm{x}} \mathrm{N}_{\mathrm{y}}$ from $\mathrm{B}_{2} \mathrm{H}_{6}$ at $300-400{ }^{\circ} \mathrm{C}$ onto p-type $\mathrm{Si}(100)$ wafers. Increasing W wire temperature enhances the nitridation and thus the BN content (Figure 4e).

In parallel, TriEthylBoron (TEB) is studied as ALD precursor. When reacted with $\mathrm{NH}_{3}$ using a fluidized bed reactor, it enables depositing $\mathrm{BN}$ on 1-5 $\mu \mathrm{m} \mathrm{Zn}$ particles in order to improve their tribological properties. Temperatures ranging from 150 to $350{ }^{\circ} \mathrm{C}$ are experienced to prevent softening or melting of $\mathrm{Zn}$ particles and to ensure sufficient reactivity of ammonia and ligand exchange with the boron precursor. TEB decomposition occurring at $350{ }^{\circ} \mathrm{C}$, lower temperature as $175{ }^{\circ} \mathrm{C}$ is chosen. However, XPS data reveal predominantly formation of boron oxide, attributed to removal of ethyl ligand by $\mathrm{NH}_{3}$ rather than nitriding that requires higher thermal energy. ${ }^{60}$

Well controlled growth of crystallized h-BN using TEB is reported on sapphire and Si substrates at $500-900{ }^{\circ} \mathrm{C},{ }^{71}$ despite precursor decomposition from $\beta$-elimination previously reported at $350{ }^{\circ} \mathrm{C} .{ }^{60}$ Exposure to $\mathrm{NH}_{3}$ directly impacts the film crystallization and impurity content while it does not affect the GPC. Moreover, temperature increase from 600 to $900{ }^{\circ} \mathrm{C}$ improves the crystallinity from amorphous to nanocrystalline coating. It turns out that the $\mathrm{NH}_{3}$ exposure time plays a weaker role on the obtained BN structures compared to the deposition temperature. Due to the decomposition contribution to the growth, the proposed process tends more to sequential CVD-like rather than ALD mode, despite some self-limiting effect around $600^{\circ} \mathrm{C}$.

In order to enhance the reactivity toward TEB, hollow-cathode $\mathrm{N}_{2} / \mathrm{H}_{2}$ plasma assisted approach is introduced by Haider et al. ${ }^{53}$ In 2014, they first report the successful growth of h-BN thin films onto silicon and quartz substrates at temperatures ranging from 250 to $450{ }^{\circ} \mathrm{C}$. Decomposition of TEB precursor being confirmed above $250{ }^{\circ} \mathrm{C}$, the proposed process is assigned to sequential CVD instead of ALD. Increase of crystallinity of the obtained thin films, in particular in term of crystallite size and refractive index is noted at $450{ }^{\circ} \mathrm{C}$, even though post annealing treatment at $800{ }^{\circ} \mathrm{C}$ for $30 \mathrm{~min}$ is required. In parallel, BN coated AIN hollow fibers are obtained combining electrospinning and sequential plasma assisted CVD of BN and AIN. ${ }^{84} \mathrm{AIN}$ is first deposited at $100{ }^{\circ} \mathrm{C}$ onto electrospun nylon 6,6 fibers, which are subsequently removed at $500{ }^{\circ} \mathrm{C}$ for $2 \mathrm{~h}$. Then, sequential CVD of BN at 
$450{ }^{\circ} \mathrm{C}$ is performed on the remaining AIN hollow fibers (Figure 4f). Peculiar 3D structure with branching features (Figure $\mathbf{4 g}$ ), attributed to the CVD growth mode, is observed for AIN/BN hollow fibers. Recently, the same group has developed this approach for fabricating $B_{x} G a_{1-x} N$ and $B_{x} \mid n_{1-x} N$ thin film alloys applicable in UV optoelectronics, high temperature and radiation/power tolerant electronics domains. ${ }^{69}$

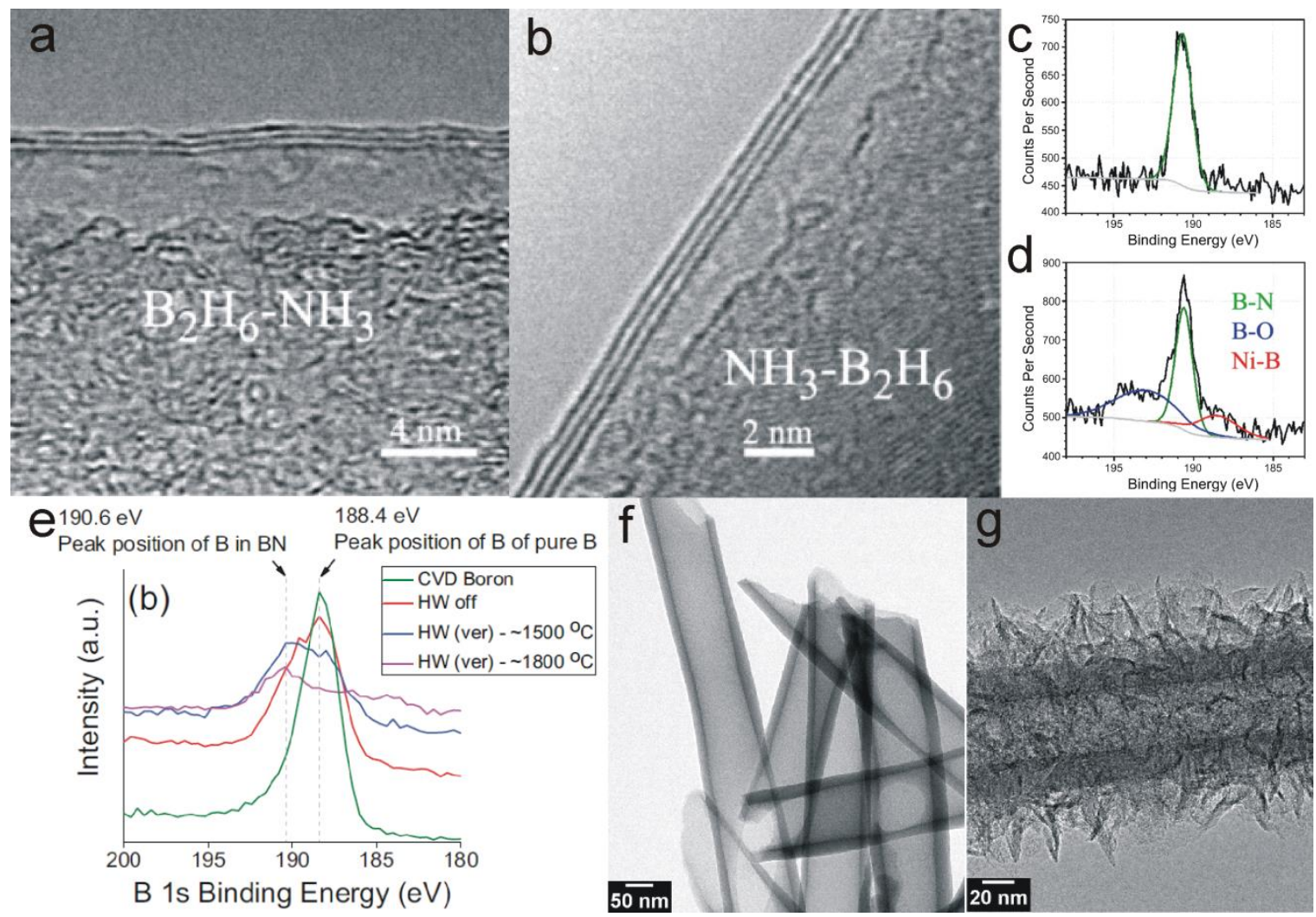

Figure 4. a,b) SEM images of BN layer depending on the reactant order a) first diborane. b) first ammonia. c,d) B 1s XPS spectrum for sequential growth c) with ammonia first and d) with diborane first. Reproduced with permission from ref. ${ }^{74}$ e) XPS B 1s spectra of pure-B deposited by CVD using $B_{2} H_{6}$ mixed with $H_{2}$, and $H W$-assisted $B_{x} N_{y}$ films deposited by sequential pulses of $\mathrm{B}_{2} \mathrm{H}_{6}$ and $\mathrm{NH}_{3}$. Reproduced with permission from ref. ${ }^{75} \mathrm{f}, \mathrm{g}$ ) Bright field TEM images of $\mathrm{f}$ ) AIN hollow fibers and $\mathrm{g}$ ) AIN/BN bishell hollow fibers. Reproduced with permission from ref. ${ }^{84}$

Processes based on diborane and organoboron appear so far limited by the lack of reactivity at low temperature of these precursors. In particular, diborane requires high deposition temperature restraining the choice of substrates. On the other hand, TEB reveals poorly reactive toward $\mathrm{NH}_{3}$ and $\mathrm{N}_{2} / \mathrm{H}_{2}$ plasma at temperature lower than its decomposition, leading to development of sequential CVD rather than ALD. Therefore, alternative precursors have been sought after to overcome these limitations.

\subsubsection{Alternative precursors}


Alternative precursors, like aminoborane and borazine have been developed as well as different approaches such as PEALD ${ }^{67}$ and Electron-Enhanced ALD (EEALD). ${ }^{76}$

In particular, Park et al. ${ }^{67}$ develop PEALD with a novel precursor containing both $\mathrm{B}$ and $\mathrm{N}$ elements. Tris(ethylmethylamino)borane (TEMAB) is reacted with $\mathrm{NH}_{3} / \mathrm{N}_{2}$ plasma at a temperature ranging from 250 to $350^{\circ} \mathrm{C}$. Linear dependence of the thickness versus the number of cycles indicates a GPC of $1.1 \AA$ A/cycle (Figure 5a). Smooth films are uniformly deposited over flat and structured substrates (as aspect ratio of 6:1) as shown in Figure $\mathbf{5 b}$. Nearly amorphous structure is evidenced by the electron diffraction pattern (Figure 5c), and the absence of long range order in HRTEM crosssectional image (Figure $\mathbf{5 d}$ ). The obtained BN layer is used as support into graphene FET and permits the electrical properties enhancement of the transferred graphene. Therefore, TEMAB seems a promising alternative precursor for $\mathrm{BN}$ fabrication, even though the layer crystallinity needs improvement.
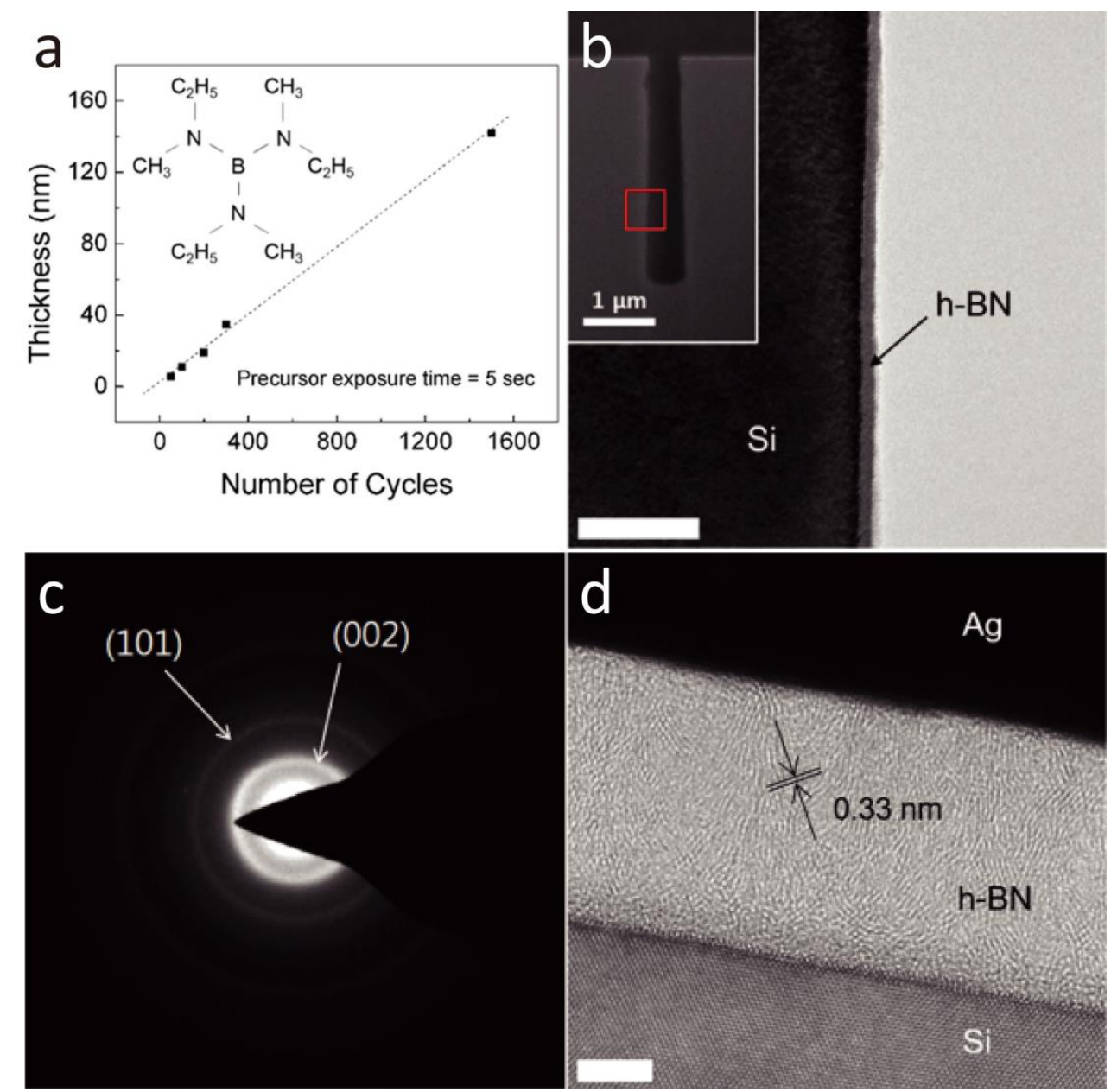

Figure 5. a) Film thickness as a function of the number of the ALD cycles, inset: the molecular structure of TEMAB. b) TEM image of a trench sidewall (aspect ratio of 6:1) coated with BN (scale bar $=100 \mathrm{~nm}$ ), inset: the corresponding SEM image. c) Electron diffraction pattern recorded from BN film on Si. d) HRTEM image of BN film on Si (scale bar = $5 \mathrm{~nm}$ ). Reproduced with permission from ref. ${ }^{67}$ 
Lately, our group has developed a novel two-step ammonia-free ALD process based on polymer derived ceramics (PDCs) chemistry. ${ }^{73}$ From trichloroborazine (TCB), a borazine derivative, and hexamethyldisilazane (HMDS), low temperature $\left(80^{\circ} \mathrm{C}\right)$ deposition of a pre-ceramic polyborazine is possible onto various substrates. Post annealing treatment permits conversion of the pre-ceramic film into stoichiometric BN thin layers. Thickness of BN linearly depends on the number of cycles (Figure 6a) and no change of GPC with longer reactants pulses is noted indicating the self-limiting character. This low temperature approach allows use of polymer as sacrificial substrate. For instance, high quality h-BN nanotube arrays (Figure $\mathbf{6 b}, \mathbf{c}$ ) as well as unwoven BN nanotube mat are successfully fabricated from, respectively, polycarbonate membrane (aspect ratio=20:1) and electrospun polyacrylonitrile fiber mat. ${ }^{73}$ Such $\mathrm{BN}$ nanostructures display superhydrophobicity (Figure 6d) and prove to be efficient for water purification. ${ }^{85}$
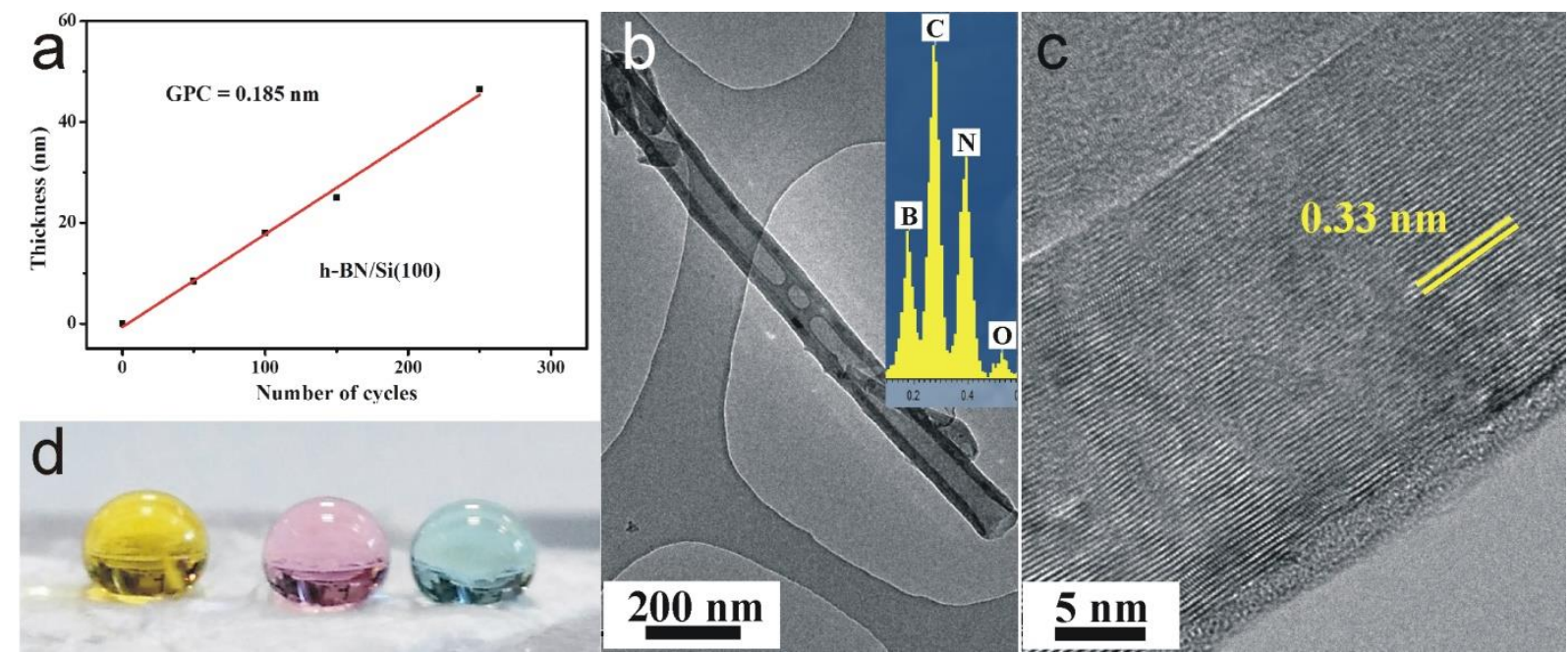

Figure 6. a) Thickness of $B N$ films deposited onto Si(100) wafer as a function of the number of ALD cycles. b) Low magnification TEM image of the BN tube obtained from polycarbonate membrane. Typical EDXS spectrum of the nanostructures is added in inset. c) HRTEM micrograph of an external BN tube wall. d) Photograph taken from droplets of aqueous solution with color indicator at pH 1 (pink), 7 (yellow) and 12 (blue) deposited on annealed unwoven BN nanotube mat. Reproduced with permission from ref. ${ }^{73}$

EEALD is reported for the first time by Sprenger et al. $^{76}$ for fabricating BN on B-doped Si(111) at room temperature and $100{ }^{\circ} \mathrm{C}$ using sequential exposure of borazine and electrons. Electron exposure leads to electron stimulated desorption of surface hydrogen arising from borazine adsorption. The GPC depends on the electron energy and a maximum value of $3.2 \AA$ /cycle is reached at $80-160 \mathrm{eV}$. BN film grows exclusively in the electron flux area as shown in Figure 7a. The obtained BN reveals turbostratic with parallel planes to the substrate (Figure $\mathbf{7 b}$ ). This orientation could be attributed to borazine adsorption on the previously anchored borazine ring that displays reactive dangling bonds generated after hydrogen desorption. It should be highlighted that only very thin BN films are 
observed along the vertical sidewall of trenches due to the misalignment of the electron flux to the surface substrate.

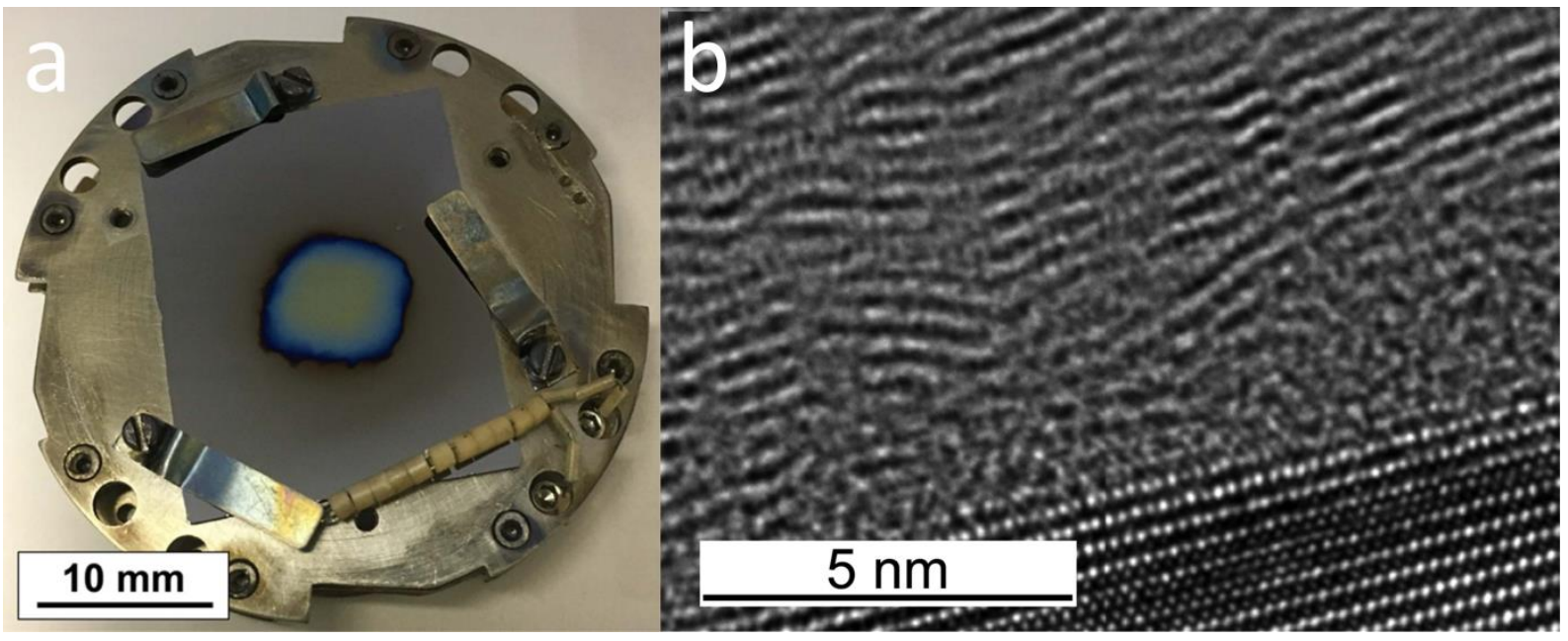

Figure 7. a) Photograph of $\mathrm{BN}$ grown at $27^{\circ} \mathrm{C}$ on $\mathrm{Si}(111)$ substrate after 500 EEALD cycles using sequential borazine and electron (100 eV) exposures. b) Cross-section HRTEM image of the deposited t-BN film onto Si(111) substrate at $100{ }^{\circ} \mathrm{C}$ showing a $\sim 1 \mathrm{~nm}$ amorphous-BN interface. Reproduced with permission from ref. ${ }^{76}$

Aminoboranes and borazine derivatives reveal to be promising alternative reactants to the conventional halide and organo precursors. They enlarge the panel of potential chemical reactions applicable in ALD. On the one side, reducing the deposition temperature enables access to large variety of support and eventually to self-supported BN layers. On the other side, aminoborane based BN layers already prove to be efficient for fabricating graphene/BN heterostructures with promising electrical properties in the view of integration into FET devices. However, one should keep in mind that PEALD and EEALD may suffer from a lack of flux homogeneity of radicals and electrons, respectively, limiting their use on structured substrate, even though they are highly efficient on planar ones. $^{86}$

To conclude, several families of boron precursors are available, nonetheless, few appear efficient for the ALD deposition of BN because of their lack of reactivity, decomposition temperature or residual contamination. On the first hand, boron halides are the most investigated reactants due to their high thermal stability, but they mostly involve reaction with ammonia and might lead to residual contaminant. On the other hand, organoborons are strongly limited by their poor thermal stability, while aminoboranes and borazine derivatives reveal suited alternative precursors for BN ALD. Further progresses are, nevertheless, required. In all cases, the crystalline quality of the as-deposited layers remains insufficient and post-annealing treatments at high temperature are currently performed. Despite these limitations, ALD already demonstrates suited to fabricate BN layers that can successfully be integrated into electronic devices like graphene-based FET. 


\begin{tabular}{|c|c|c|c|c|c|c|c|c|}
\hline Material & Technique & Reactants & Substrate & $\begin{array}{l}\text { Operating } \\
\text { temperature }\end{array}$ & Post-treatment & Crystallinity & Application & Ref. \\
\hline \multirow{4}{*}{ Graphene } & PEALD & Benzene/ $\mathrm{H}_{2} /$ Ar plasma & Cu foil & $400^{\circ} \mathrm{C}$ & None & Hexagonal & - & 45 \\
\hline & \multirow[t]{3}{*}{ ALET } & $\begin{array}{c}\text { Metal/etching solution } \\
\text { couple: } \\
\mathrm{Zn} / \mathrm{HCl} \\
\mathrm{Al} / \mathrm{HCl} \\
\mathrm{Al} / \mathrm{NaOH} \\
\mathrm{Cu} / \mathrm{HCl} / \mathrm{CuCl}{ }_{2} \\
\mathrm{Au} / \mathrm{KI} / \mathrm{I}_{2} \\
\end{array}$ & $\begin{array}{l}\text { CVD graphene, GO, exfoliated } \\
\text { graphene }\end{array}$ & - & None & - & Patterning & 32 \\
\hline & & $\mathrm{O}_{2}$ radical ads $/ \mathrm{Ar}^{+}$desorp & $\begin{array}{l}\text { Exfoliated HOPG } \\
\text { CVD graphene }\end{array}$ & - & $\begin{array}{c}\text { None } \\
1000{ }^{\circ} \mathrm{C} \text { for } 30 \text { min } \\
\text { in } \mathrm{H}_{2} / \mathrm{He}\end{array}$ & $\begin{array}{l}\text { Damaged graphene } \\
\text { Mostly recovered }\end{array}$ & FET & $\begin{array}{l}46 \\
47\end{array}$ \\
\hline & & $\begin{array}{c}\mathrm{O}_{2} \text { radical ads/Ar }{ }^{+} \text {desorp - } \\
\text { Optimized }\end{array}$ & CVD graphene & - & None & Graphene & - & 50 \\
\hline \multirow{16}{*}{$\mathrm{BN}$} & LALD & \multirow{4}{*}{$\mathrm{BBr}_{3} / \mathrm{NH}_{3}$} & $\alpha-\mathrm{Al}_{2} \mathrm{O}_{3}, \mathrm{SiO}_{2}$ & $250-750^{\circ} \mathrm{C}$ & None & $\mathrm{t}-\mathrm{BN}$ & - & 68 \\
\hline & \multirow{15}{*}{ ALD } & & $\mathrm{SiO}_{2}$ & $400,750^{\circ} \mathrm{C}$ & None & $\mathrm{a}-\mathrm{BN}, \mathrm{t}-\mathrm{BN}$ & - & 58 \\
\hline & & & $\mathrm{AAO}, \mathrm{SiO}_{2} / \mathrm{Si}, \mathrm{CF}$ & $750^{\circ} \mathrm{C}$ & $\begin{array}{l}\text { None } \\
1000^{\circ} \mathrm{C}\end{array}$ & $\begin{array}{c}\mathrm{t}-\mathrm{BN} \\
\text { cristalline BN }\end{array}$ & $\begin{array}{l}\text { Osmotic energy conversion, } \\
\text { ionic separation, ultrafiltration }\end{array}$ & 62 \\
\hline & & & $\mathrm{SiO}_{2} / \mathrm{Si}$ & $750^{\circ} \mathrm{C}$ & $\begin{array}{c}\text { None } \\
10000^{\circ} \mathrm{C} \text { or } 1350^{\circ} \mathrm{C} \\
\text { for } 3 \mathrm{~h} \\
\end{array}$ & $\begin{array}{c}t-B N \\
w-B N \\
w-B N+h-B N \\
\end{array}$ & 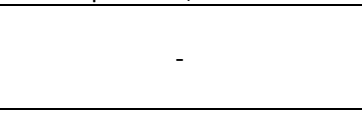 & 78 \\
\hline & & \multirow{8}{*}{$\mathrm{BCl}_{3} / \mathrm{NH}_{3}$} & $\mathrm{ZrO}_{2}$ particles & $350-500 \mathrm{~K}$ & $\begin{array}{l}\text { Annealing up to } \\
1100 \mathrm{~K} \\
\end{array}$ & $a-B N$ & - & 59 \\
\hline & & & Al particles & $325^{\circ} \mathrm{C}$ & None & $a-B N$ & $\begin{array}{c}\text { Metal-insulator varistors } \\
\text { (MIVs) }\end{array}$ & 72 \\
\hline & & & $\mathrm{Ru}(0001)$ & $550 \mathrm{~K}$ & $\begin{array}{c}\text { Annealing in UHV } \\
\text { up to } 1000 \mathrm{~K}\end{array}$ & $\begin{array}{l}\mathrm{h}-\mathrm{BN}(0001) \\
\text { monolayer }\end{array}$ & $\begin{array}{c}\text { Graphene/h-BN(0001) } \\
\text { heterojunction }\end{array}$ & 65 \\
\hline & & & $\mathrm{RuO}_{2}(110) / \mathrm{Ru}(0001)$ & $600 \mathrm{~K}$ & None & h-BN(0001) & - & 81 \\
\hline & & & $\mathrm{SiO}_{2} / \mathrm{Si}(100)$ & $630^{\circ} \mathrm{C}$ & $\begin{array}{c}700-1000^{\circ} \mathrm{C} \text { in } \mathrm{N}_{2} \\
\text { at } 1 \text { Torr }\end{array}$ & - & B doping application & 63 \\
\hline & & & $\begin{array}{c}\text { Si-terminated } \mathrm{CoSi}_{2}(111) / \mathrm{Si}(111) \\
\mathrm{Ru}(0001)\end{array}$ & $550 \mathrm{~K}$ & $\begin{array}{c}\text { Annealing in UHV } \\
\text { up to } 1000 \mathrm{~K}\end{array}$ & h-BN(0001) & $\begin{array}{l}\text { Integration of graphene with } \\
\text { silicon } \\
\end{array}$ & 80 \\
\hline & & & $\mathrm{Co}(0001)$ & $\begin{array}{l}550 \mathrm{~K} \\
600 \mathrm{~K}\end{array}$ & $\begin{array}{l}\text { Annealing in UHV } \\
\text { up to } 800 \mathrm{~K} \\
\text { None }\end{array}$ & $\begin{array}{l}\text { h-BN(0001) bilayer } \\
\text { and trilayer } \\
\text { h-BN(0001) }\end{array}$ & $\begin{array}{c}\text { Epitaxial Co/BN } \\
\text { heterojunctions } \\
\text { Graphene/h- } \\
\text { BN(0001)/Co(0001) }\end{array}$ & ${ }^{79}$ \\
\hline & & & $\begin{array}{l}\text { Aluminum particles } \\
\text { Metal particles } \\
\end{array}$ & $230^{\circ} \mathrm{C}$ & None & $a-B N$ & Solid lubricating coating & 60 \\
\hline & & $\mathrm{BCl}_{3} / \mathrm{N}_{2} \mathrm{H}_{4}$ & $\mathrm{Si}_{0.3 \mathrm{G}} \mathrm{Ge}_{0.7}(001), \mathrm{Cu}, \mathrm{HOPG}$ & $350^{\circ} \mathrm{C}$ & None & $a-B N$ & - & 82,83 \\
\hline & & TCB/HMDS & $\begin{array}{l}\text { Si, polycarbonate membrane, } \\
\text { electrospun polyacrylonitrile fibers }\end{array}$ & $80^{\circ} \mathrm{C}$ & $1000-1400{ }^{\circ} \mathrm{C}$ & $t-B N, h-B N$ & Water purification & 73,85 \\
\hline & & \multirow{2}{*}{$\mathrm{TEB} / \mathrm{NH}_{3}$} & Spherical Zn powder & $150-350^{\circ} \mathrm{C}$ & None & $a-B N$ & Solid lubricating coating & 60 \\
\hline & & & Sapphire (0001), Si(001) & $500-900{ }^{\circ} \mathrm{C}$ & None & $a-B N$, & - & 71 \\
\hline
\end{tabular}




\begin{tabular}{|c|c|c|c|c|c|c|c|c|}
\hline & & & & Self-limiting at $600^{\circ} \mathrm{C}$ & & $\begin{array}{c}\text { nanocrystalline t-BN } \\
\left(900^{\circ} \mathrm{C}\right)\end{array}$ & & \\
\hline & & \multirow[t]{2}{*}{$\mathrm{TEB} / \mathrm{N}_{2} / \mathrm{H}_{2}$ plasma } & Si(100), quartz & $\begin{array}{c}250-450^{\circ} \mathrm{C} \\
\text { Sequential CVD at } \\
350 \text { and } 450^{\circ} \mathrm{C}\end{array}$ & $800^{\circ} \mathrm{C}$ for $30 \mathrm{~min}$ & Polycrystalline h-BN & - & 53 \\
\hline & \multirow{3}{*}{$\begin{array}{c}\text { Sequential } \\
\text { CVD }\end{array}$} & & AIN hollow nanofibers & $450^{\circ} \mathrm{C}$ & None & Polycrystalline h-BN & - & ${ }^{84}$ \\
\hline & & \multirow{2}{*}{$\mathrm{B}_{2} \mathrm{H}_{6} / \mathrm{NH}_{3}$} & Ni foil & $1025^{\circ} \mathrm{C}$ & None & $h-B N$ & - & 74 \\
\hline & & & $\mathrm{Si}(100)$ & $300-400{ }^{\circ} \mathrm{C}$ & None & - & - & 75 \\
\hline & PEALD & TEMAB $/ \mathrm{NH}_{3} / \mathrm{N}_{2}$ plasma & $\mathrm{Si}$ & $250-350^{\circ} \mathrm{C}$ & None & Near amorphous BN & $\begin{array}{l}\text { h-BN-containing capacitors } \\
\text { and graphene FETs }\end{array}$ & 67 \\
\hline & EEALD & Borazine/electrons & Boron-doped Si(111) & 27 and $100^{\circ} \mathrm{C}$ & None & $\mathrm{t}-\mathrm{BN}$ & - & ${ }^{76}$ \\
\hline $\begin{array}{c}\mathrm{B}_{x} \mathrm{Ga}_{1-\mathrm{x}} \mathrm{N} \text { and } \\
\mathrm{B}_{\mathrm{x}} \mathrm{x} \mathrm{n}_{1-\mathrm{x}} \mathrm{N}\end{array}$ & $\begin{array}{l}\text { Sequential } \\
\text { CVD }\end{array}$ & $\mathrm{TEB} / \mathrm{N}_{2} / \mathrm{H}_{2}$ plasma & $\mathrm{Si}(100)$, quartz & $450^{\circ} \mathrm{C}$ & None & - & - & 69 \\
\hline
\end{tabular}




\section{2D metal dichalcogenides}

In parallel to the intensive research on graphene-like materials, layered metal dichalcogenides $\left(\mathrm{MX}_{2}\right.$, $\mathrm{X}=\mathrm{S}$, Se, Te) have attracted great attention due to their promising electrical and optical properties. ${ }^{4}$ These structures are composed of a metal layer covalently bonded with two surrounding chalcogen ones, forming a sandwich structure considered as one single layer. Each of these layers is weakly bonded to the others by $\mathrm{VdW}$ interactions, allowing their exfoliation into 2D sheets. However, only few 2D TMDs, mostly $\mathrm{MoX}_{2}$ and $\mathrm{WX}_{2}$, are currently reported stable $\left(\mathrm{MoS}_{2}, \mathrm{WS}_{2}, \mathrm{MoSe}_{2}, \mathrm{WSe}_{2}\right)$ or probably stable ( $\mathrm{MoTe}_{2}, \mathrm{WTe}$ ) as monolayer under ambient conditions, other $\mathrm{MX}_{2}$ monolayers being unlikely stable in air. ${ }^{17}$ Exfoliation and CVD techniques are widely employed to fabricate such 2D materials but challenges remain in term of combining homogeneity, crystalline quality, large scaling and processing cost. ${ }^{4}$ On the other hand, ALD of metal sulfides and generally of metal chalcogenides has been early investigated with ZnS as one of the first ALD deposited material. ${ }^{87}$ Nowadays, more than 25 binary, ternary or doped chalcogenides are synthesized using this technique. ${ }^{31,88-93}$ Few recent reviews focus on ALD of chalcogenide materials. ${ }^{29,33,36,37}$ In particular, Dasgupta et al. ${ }^{33}$ summarize progresses on "atomic layer deposition of metal sulfide materials" and discuss the specific chemistry involved. In 2015, ALET has been applied to this material family to control the number of CVD MoS 2 layers. ${ }^{94}$ Later on, based on typical ALD half-reactions, Self-Limiting layer Synthesis (SLS) of 2D TMDs monolayer has been reported. ${ }^{95,96}$

Herein, stable 2D TMDs fabricated by atomic layer techniques will be presented (summarized in Table 2) and discussed in details. A brief overview of ALD synthesis of other layered metal chalcogenides will also be given.

\subsection{Fabrication of $\mathrm{MoS}_{2}$}

Molybdenum disulfide is the most investigated stable 2D TMDs, due to its promising applications in electronics and catalysis areas. It displays hexagonal structure with covalent S-Mo-S atom arrangement along the $\mathrm{z}$ axis and $\mathrm{VdW}$ interaction between layers. Since the last five years, atomic layer processes are developed for $\mathrm{MoS}_{2}$ thin layer formation. Sulfidation of $A L D \mathrm{MoO}_{3}$ film (see part 3.1.) is first realized. Wang et al. ${ }^{97}$ report the formation of $\mathrm{MoS}_{2}$ onto carbon paper and $\mathrm{SiO}_{2} / \mathrm{Si}$, after treatment, at $600{ }^{\circ} \mathrm{C}$ for 10 min under $\mathrm{S}$ vapors, of $\mathrm{ALD} \mathrm{MoO}_{3}$ film deposited from $\mathrm{Mo}(\mathrm{CO})_{6}$ and ozone. The synthesized 2D TMD presents layers perpendicular to the substrate that thus expose active edge sites suited for Li intercalation and Hydrogen Electrochemical Reduction (HER). Two recent studies deal with the importance of $\mathrm{MoO}_{\mathrm{x}}$ morphology, composition and nucleation as well as 
of the sulfidation parameters on the engineering of $\mathrm{MoS}_{2}$ layers, in term of coverage, uniformity, thickness and crystallinity. ${ }^{98,99}$ While control of the number and homogeneity of TMD layers is expected to be simply realized through the control of the $\mathrm{MoO}_{3}$ film, oxide-substrate interaction and density of nucleation sites for $\mathrm{MoO}_{\mathrm{x}}$ strongly impact the uniformity of ultra-thin sulfide due to dewetting phenomenon. The latter can be tuned either by increasing the stoichiometry of the oxide and/or by adapting the support as demonstrated by the successful synthesis of two $\mathrm{MoS}_{2}$ layers on monocrystalline sapphire which interact less with $\mathrm{MoO}_{3}$ than $\mathrm{SiO}_{2}{ }^{98}$ Tuning the ALD oxide nucleation, using for instance PEALD and/or substrate pre-treatment, also directly influences the coverage of the resulting sulfide film. Indeed, $\mathrm{MoS}_{2}$ layer showing full coverage is more likely produced from uniform ultra-thin $\mathrm{MoO}_{x}$ film than from a particulate one. Finally, multistep annealing permits to separate the formation of $\mathrm{MoS}_{2}$ (reduction of Mo/incorporation of S) and thus its coverage control, from its crystallization into $2 \mathrm{H}$-phase at higher temperature. ${ }^{99}$

In 2014, the first ALD process of $\mathrm{MoS}_{2}$, which employs $\mathrm{MoCl}_{5}$ and $\mathrm{H}_{2} \mathrm{~S}$ as reactants and an exposure mode, is reported by Tan et al. ${ }^{100}$ Coating of two inch sapphire wafer at $300{ }^{\circ} \mathrm{C}$ is demonstrated. Because of an island growth at the nucleation stage, a minimum of 10 cycles is required to form a continuous film. TEM and XRD reveal the hexagonal structure of the as-deposited $\mathrm{MoS}_{2}$, while photoluminescence spectrum suggests insufficient film quality as no excitonic feature is observed. Post-annealing at $800{ }^{\circ} \mathrm{C}$ under saturated sulfur vapor enhances the crystallization but reduces the thickness. Therefore, 20 ALD cycles instead of 10 are required for full coverage. On the other hand, growth performed at the ALD window ranging from 350 to $450{ }^{\circ} \mathrm{C}$ permits obtaining good quality sulfide layer that displays excitonic features, over large surface area without any post-processing. ${ }^{101}$ An average GPC of $0.087 \mathrm{~nm} /$ cycle on $\mathrm{SiO}_{2} / \mathrm{Si}$ is observed. At $450{ }^{\circ} \mathrm{C}$, mix of continuous film and triangular isolated monolayered flakes is reported after one ALD cycle. ${ }^{102}$ Linear relationship between the number of $\mathrm{MoS}_{2}$ layers and the number of cycles is also noted. Influence of the deposition temperature on the film morphology is further investigated in the range of $420-480{ }^{\circ} \mathrm{C}$ by Huang et al. ${ }^{103}$ Nanocrystalline layers highly oriented parallel to the substrate are synthesized with a GPC of 0.38 and $0.43 \mathrm{~nm} /$ cycle onto $\mathrm{Si}$ with native oxide and $\mathrm{Al}_{2} \mathrm{O}_{3}$, respectively. It should be noted that this growth rate is significantly higher than that previously reported. While porous films are deposited at $420{ }^{\circ} \mathrm{C}$, higher growth temperatures produce compact films with the largest grain size at $450{ }^{\circ} \mathrm{C}$. Deposition in the range of $430-470{ }^{\circ} \mathrm{C}$ leads to hexagonal $\mathrm{MoS}_{2}$ planes with preferential parallel orientation towards the support. Valdivia et al. ${ }^{104}$ demonstrate the uniform deposition at $475{ }^{\circ} \mathrm{C}$ of mono- to few layers thick $\mathrm{MoS}_{2}$ coating over $150 \mathrm{~mm} \mathrm{SiO} / 2$ Si wafer. Sulfur sub-stoichiometry $(\mathrm{S} / \mathrm{Mo}=$ 1.4) as well as crystalline orientation parallel to the substrate is observed on as-deposited films. Their 
quality is further improved by annealing under either $\mathrm{H}_{2} \mathrm{~S}$ or $\mathrm{S}$ vapors as revealed by XPS displaying S/Mo ratio near 2 and sharpening of Raman bands.

In 2016, Kim et al. ${ }^{95}$ report the controlled fabrication of mono-, bi-, and tri-layers of $\mathrm{MoS}_{2}$ from $\mathrm{MoCl}_{5}$ reacted with $\mathrm{H}_{2} \mathrm{~S}$ using a self-limiting layer synthesis. This approach, seen as an ALD derivative, is based on the chemical inertness of the basal plane of the 2D TMDs restraining additional layer deposition. Once the first crystalline TMDs monolayer is formed, limited amount of anchors remains available due to the lack of reactivity of 2D surface and further growth mainly occurs through $\mathrm{MoCl}_{5}$ physisorption. However, deposition at high temperature tends to favor the precursor desorption preventing additional coating. The number of deposited layers saturates after a certain number of cycles (Figure 8a), at the opposite of conventional ALD in which exists a linear relationship between the thickness and the cycle number. Indeed, different growth mechanism is involved in SLS which is temperature determined. As evidenced by AFM and Raman spectra (Figure $\mathbf{8 b}, \mathbf{c}$ ), three, two and one well-crystallized layers are fabricated with wafer-scale uniformity at, respectively, 500, 700 and 900 ${ }^{\circ} \mathrm{C}$, independently on the number of cycles. The synthesized $\mathrm{MoS}_{2}$ appears promising for $\mathrm{p}$-n diode device based on $\mathrm{MoS}_{2} / \mathrm{WSe}_{2}$ heterojunction.
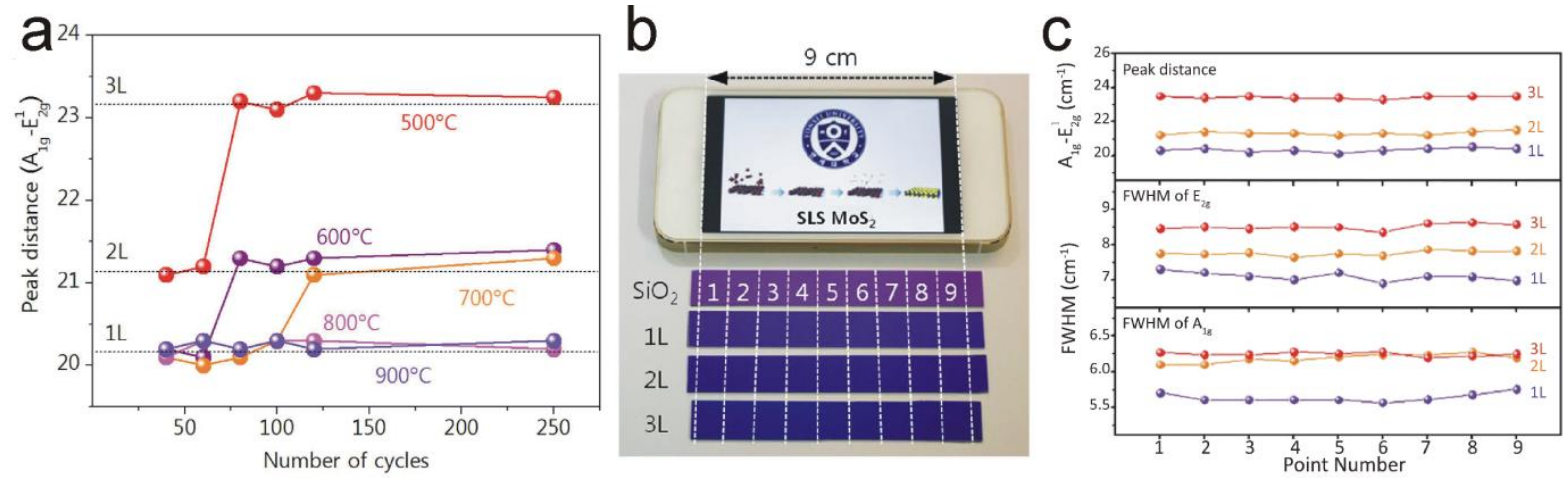

Figure 8. a) Raman peak distances for $\mathrm{MoS}_{2}$ depending on SLS cycle number and growth temperatures. b) Photograph of wafer scale $(\sim 9 \mathrm{~cm})$ mono-, bi-, and tri-layer $\mathrm{MoS}_{2}$ deposited on a $\mathrm{SiO}_{2}$ substrate using SLS and c) their corresponding measured peak distances and FWHM of Raman $E_{2 g}^{1}$ and $A_{g}^{1}$ modes at nine different positions marked in b). Reproduced with permission from ref. ${ }^{95}$.

In addition to Molybdenum halide, other Mo compounds are used as ALD precursors. In particular, $\mathrm{Mo}(\mathrm{CO})_{6}$ is reacted with either $\mathrm{H}_{2} \mathrm{~S}$ or dimethyldisulfide (DMDS, $\mathrm{CH}_{3}-\mathrm{S}-\mathrm{S}-\mathrm{CH}_{3}$ ). Nearly simultaneously than Tan's work, Nandi et al. ${ }^{105}$ investigate $\mathrm{MoS}_{2}$ fabrication from $\mathrm{Mo}(\mathrm{CO})_{6}$ and $\mathrm{H}_{2} \mathrm{~S}$ using in situ Quartz Crystal Microbalance (QCM) and FTIR characterization combined with ex-situ measurements. The ALD window of the process ranges from 155 to $170{ }^{\circ} \mathrm{C}$. Typical Raman signature of S-Mo-S bond is noted despite an amorphous structure. Monitoring the mass gain reveals that multiple pulses of Mo source are required to reach the saturation, while a single $\mathrm{H}_{2} \mathrm{~S}$ injection is sufficient (Figure 9a). Indeed a GPC of $2.5 \AA$ compared to $0.75 \AA$ /cycle ${ }^{106}$ on $\mathrm{Si}$ is noted when multiple pulses are used. 
Complete removal of $\mathrm{CO}$ ligands by hydrogen sulfide and Mo/S ratio of 1/2.1 is demonstrated by in situ IR study and XPS, respectively. ${ }^{105}$ However, further XPS investigation reveals presence of $\mathrm{Mo}^{6+}$ assigned to $\mathrm{MoO}_{3}$ and surface oxidation. Longer $\mathrm{H}_{2} \mathrm{~S}$ injections permits diminishing impurity content such as oxygen into the as-grown film, without noticeable S-S bond formation. It should be pointed out that above $175{ }^{\circ} \mathrm{C}$ precursor decomposition is evidenced by large amount of oxide. Post annealing using Rapid Thermal Annealing (RTA) under $\mathrm{H}_{2} \mathrm{~S}$ allows crystallization of the as-grown $\mathrm{MoS}_{2}$ layer and removal of oxygen contaminant. Well crystalline smooth layers are obtained after $5 \mathrm{~min}$ at $900{ }^{\circ} \mathrm{C} .{ }^{106}$ The as-fabricated layers from $\mathrm{Mo}(\mathrm{CO})_{6}$ and $\mathrm{H}_{2} \mathrm{~S}$ reveal suited for $\mathrm{Li}$ ion battery, ${ }^{105}$ and catalysis of oxygen evolution reaction. ${ }^{107}$ Crystalline $\mathrm{MoS}_{2}$ nanoparticles ALD grown at $200{ }^{\circ} \mathrm{C}$ on Co porous foam exhibit high catalytic activity and long term stability, indeed. ${ }^{107}$ It should be pointed out that, in this work, the deposition is performed outside of the previously reported ALD window. Recently, PEALD has been investigated by Jang et al. ${ }^{108}$ Using $\mathrm{H}_{2} \mathrm{~S}$ plasma, polycrystalline h-MoS films (Figure 9b) are directly deposited in a self-limiting and uniform manner onto $\mathrm{SiO}_{2} / \mathrm{Si}, \mathrm{GaN}$ and sapphire substrates from 175 to $225^{\circ} \mathrm{C}$. Nevertheless, a low GPC of $0.5 \AA$ A/cycle is observed at the ALD window $\left(175-200{ }^{\circ} \mathrm{C}\right)$, and short nucleation delay as well as formation of nanoparticles (Figure 9c), is noted on $\mathrm{SiO}_{2} / \mathrm{Si}$ wafer. ${ }^{108,109}$ Even though nanocrystals are directly formed on the substrate, post annealing under $\mathrm{H}_{2} \mathrm{~S}$ atmosphere permits to significantly improve the crystallinity (Figure 9c). Taking advantage of the initial island growth, $\mathrm{MOS}_{2}$ PEALD is employed to fabricate electrocatalyst for HER. ${ }^{109}$ Finally, investigated by 20 min pulse of $\mathrm{Mo}(\mathrm{CO})_{6}$, decomposition of the Mo source is observed from $225-250{ }^{\circ} \mathrm{C},{ }^{108}$ whereas Pyeon et al. ${ }^{106}$ report its onset at $175^{\circ} \mathrm{C}$ using temperature dependence of the GPC combined with XPS characterization. Instead of $\mathrm{H}_{2} \mathrm{~S}$, DMDS has also been early reported as $S$ source, ${ }^{110-112}$ offering new chemical route based on thiol desulfurization as shown in Scheme 1. ${ }^{110}$ Deposition at low temperature, starting above $60^{\circ} \mathrm{C}$, is possible and narrow ALD window (100$120{ }^{\circ} \mathrm{C}$ ) is observed. In particular, ALD at $100{ }^{\circ} \mathrm{C}$ allows formation on Si wafer of amorphous $\mathrm{MoS}_{2}$ continuous layer displaying typical S-Mo-S Raman peaks. Further annealing at $900{ }^{\circ} \mathrm{C}$ using RTA leads to crystallized hexagonal layer as evidenced by the TEM image in Figure 9d. ${ }^{110}$ An island growth mode with formation of amorphous and nanocrystalline $\mathrm{MoS}_{2}$ particles is noted on carbon fibers due to the lack of anchors. Such TMD particles on carbon material are particularly of interest as catalyst for HER due to their number of active sites and good adhesion to the support. ${ }^{111}$ One of the highest turnover frequencies of $\mathrm{MOS}_{2}$ reported so far is observed with catalyst ALD deposited on Au from $\mathrm{Mo}(\mathrm{CO})_{6}$ and DMDS, indeed. ${ }^{112}$ 

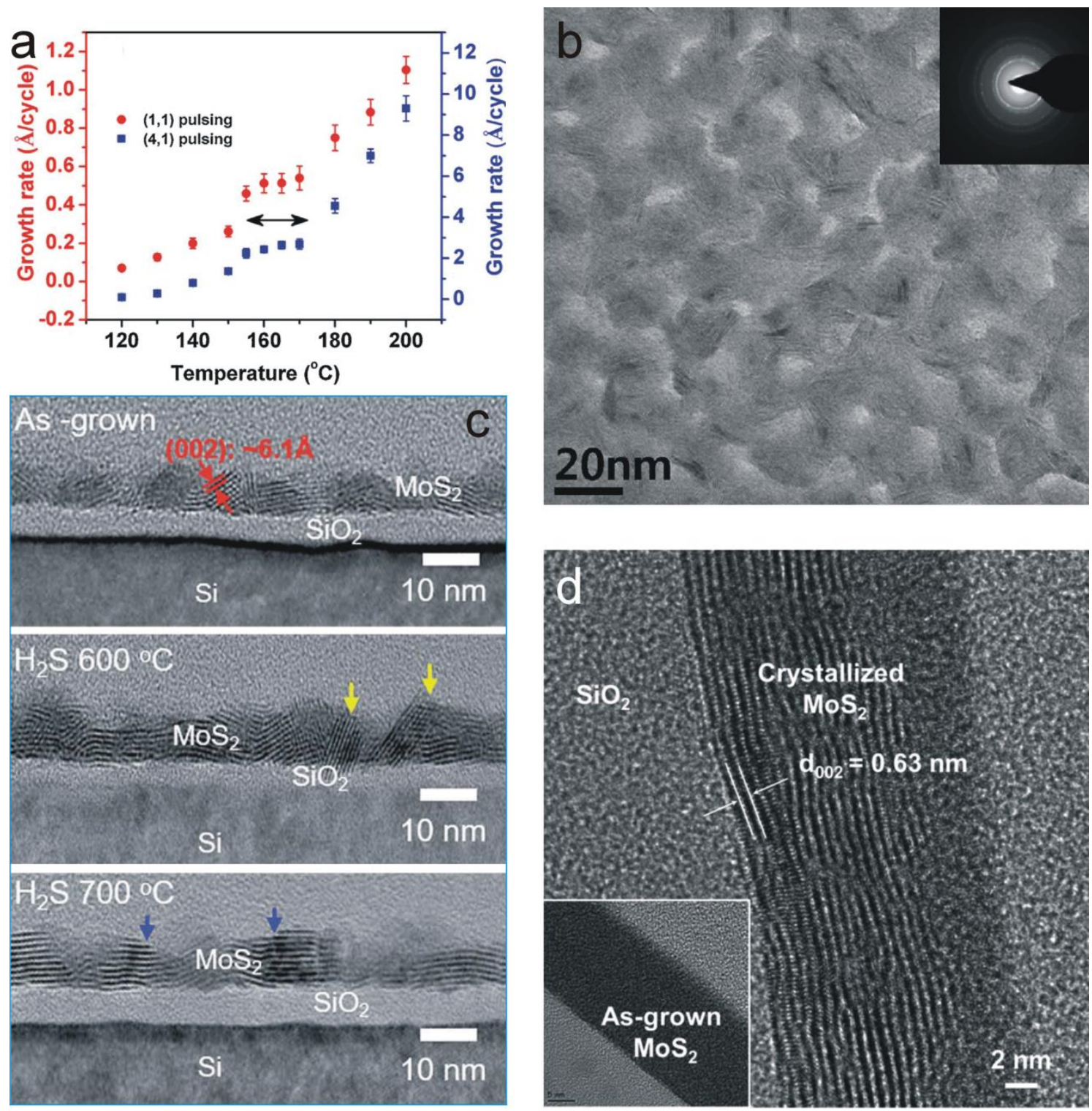

Figure 9. a) GPC of ALD from $\mathrm{Mo}(\mathrm{CO})_{6}$ and $\mathrm{H}_{2} \mathrm{~S}$ as a function of the deposition temperature and pulse lengths of Mo and $\mathrm{S}$ source. Reproduced with permission from ref. ${ }^{105}$. b) TEM image of PEALD $\mathrm{MoS}_{2}$ deposited on $\mathrm{SiO}_{2}$, inset: corresponding selected area electron diffraction pattern. Reproduced with permission from ref. ${ }^{108} \mathrm{c}$ ) Cross section TEM images of asdeposited and annealed films at $600{ }^{\circ} \mathrm{C}$ and $700{ }^{\circ} \mathrm{C}$ under $\mathrm{H}_{2} \mathrm{~S}$ reveal an island growth. Blue arrows indicate the edge sites of the (002) basal plane. Reproduced with permission from ref. ${ }^{109}$. d) Cross section TEM images of $\mathrm{MoS}_{2}$ film deposited by ALD using $\mathrm{Mo}(\mathrm{CO})_{6}$ and $\mathrm{DMDS}$ and subsequently annealed at $900{ }^{\circ} \mathrm{C}$ for $5 \mathrm{~min}$. Inset: TEM image of the as-grown film. Reproduced with permission from ref. ${ }^{110}$.

$$
\begin{aligned}
& \left|-S+M o(C O)_{6}(g) \rightarrow\right|-S-M o(C O)_{n}+(6-n) C O(g) \\
& \left|-M o(C O)_{n}+\mathrm{CH}_{3} S_{2} C H_{3}(g) \rightarrow\right|-M o-S+\text { byproduct }(g)
\end{aligned}
$$

Scheme 1. Involved half-reactions during 1) $\mathrm{Mo}(\mathrm{CO})_{6}$ and 2) DMDS pulse where | - correspond to the surface species. ${ }^{110}$

Films of $\mathrm{MoS}_{2}$ are successfully deposited by ALD from either $\mathrm{MoCl}_{5}$ or $\mathrm{Mo}(\mathrm{CO})_{6}$; however to overcome some limitations as production of corrosive acid, precursor decomposition at low 
temperature and narrow ALD window, alternative precursors have been developed. Mattinen et al. ${ }^{113}$ report the use of $\mathrm{Mo}(\text { thd })_{3}$ (thd = 2,2,6,6-tetramethylheptane-3,5-dionato) reacting with $\mathrm{H}_{2} \mathrm{~S}$. This Mo precursor appears suited for ALD as it displays a clear thermogravimetric profile with a low mass residue of $0.3 \%$. Growth is observed from $250{ }^{\circ} \mathrm{C}$ with a corresponding GPC of $0.005 \AA$ A $/$ cycle, while decomposition occurs at $350{ }^{\circ} \mathrm{C}$. Low GPC, ranging from $0.025 \AA$ to $0.065 \AA$ /cycle at $300{ }^{\circ} \mathrm{C}$, depending on the substrate, is attributed to steric hindrance of the Mo precursor and to the low amount of thiol anchors on $\mathrm{MoS}_{2}$ basal planes. Near stoichiometric crystalline films can be obtained onto various substrates, despite nucleation delay and surface roughness related to an island growth. However, it should be mentioned that carbon contamination and surface oxidation are identified by XPS and time-of-flight elastic recoil detection analysis. In addition to $\mathrm{Mo}(\mathrm{thd})_{3}$, tetrakis(dimethylamido) Molybdenum $\left(\mathrm{Mo}\left(\mathrm{NMe}_{2}\right)_{4}\right.$ is successively reacted with either $\mathrm{H}_{2} \mathrm{~S}$ or alternatively 1,2 ethanedithiol $\left(\mathrm{HS}\left(\mathrm{CH}_{2}\right)_{2} \mathrm{SH}\right) .{ }^{114,115}$ Decomposition of $\mathrm{Mo}\left(\mathrm{NMe}_{2}\right)_{4}$ occuring above 120 ${ }^{\circ} \mathrm{C}$ (Figure 10a), both ALD processes occur at very low temperature $\left(\mathrm{T}<120^{\circ} \mathrm{C}\right)$ and produce amorphous film. Subsequent annealing under inert atmosphere allows films crystallization. On the one hand, $\mathrm{H}_{2} \mathrm{~S}$ based ALD is studied using QCM technique. It reveals the mass gain during the pulse of Mo precursor, while a mass loss is noted during the injection of $S$ source due to the removal of the remaining surface $\mathrm{NMe}_{2}$ ligands. Polycrystalline, smooth and continuous films displaying strong photoluminescence and Raman signal are obtained after heat treatment up to $1000^{\circ} \mathrm{C}$. No remaining carbon based ligand or surface oxidation is noted. One of the main advantages of this process is its low deposition temperature, as low as $60{ }^{\circ} \mathrm{C}$, which allows coating of polymer substrate. This approach offers thereby the possibility of film patterning by lift-off method, as demonstrated in Figure 10b, and has never been reported for fabrication of $\mathrm{MoS}_{2}$ based devices up to the work of Jurca et al. ${ }^{114}$ On the other hand, 1,2 ethanedithiol based ALD approach consists of a two-step process with formation at $50{ }^{\circ} \mathrm{C}$ of a $\mathrm{Mo}(\mathrm{IV})$ thiolate layer which is then converted into crystalline hexagonal $\mathrm{MoS}_{2}$ using thermal annealing. The ability of 1,2 ethanedithiol to break Mo-N bonds and to provide S-H species (Figure 10c) is evidenced by IR spectroscopy and elemental analysis. Almost defect free single crystalline domains (Figure 10d) are provided by thermal conversion of the formed amorphous layer. The annealing step is monitored using in operando IR study coupled with in line gas chromatography coupled mass spectroscopy. ${ }^{115}$ 

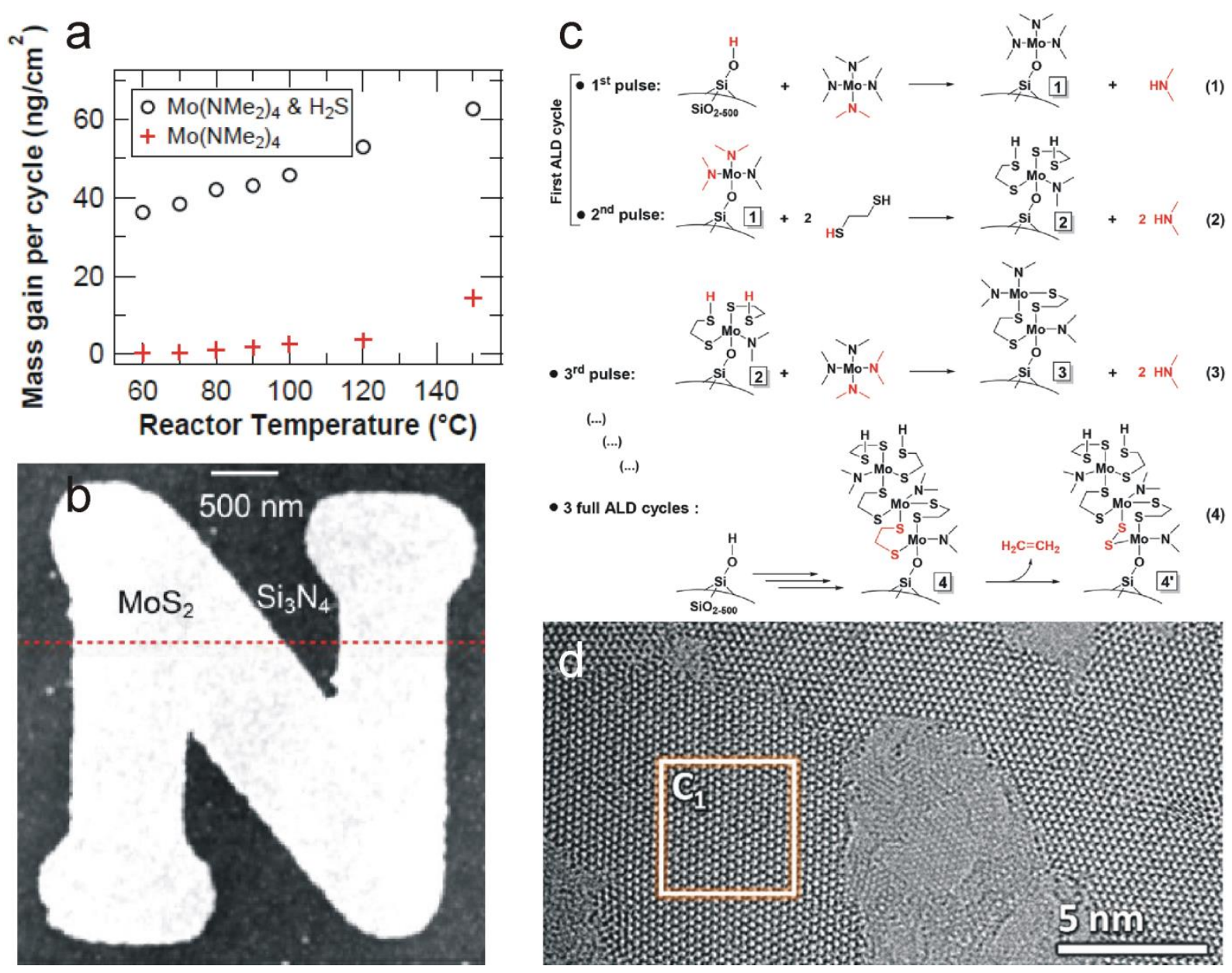

Figure 10. a) GPC, determined using QCM, as a function of the deposition temperature of ALD process based on $\mathrm{Mo}\left(\mathrm{NMe}_{2}\right)_{4}$ reacted with $\mathrm{H}_{2} \mathrm{~S}$ (black circles) and of $\mathrm{Mo}\left(\mathrm{NMe}_{2}\right)_{4} \mathrm{CVD}$ (red markers). b) AFM image of patterned $\mathrm{MoS}_{2}$ on $\mathrm{Si}_{/} \mathrm{Si}_{3} \mathrm{~N}_{4}$ using ALD, electron-beam lithography and lift-off. Reproduced with permission from ref. ${ }^{114}$. c) Scheme of the suggested reaction mechanism involved during ALD using $\mathrm{Mo}\left(\mathrm{NMe}_{2}\right)_{4}$ and 1,2 ethanedithiol and d) TEM image of the obtained film after 3 cycles and annealing at $800^{\circ} \mathrm{C}$ for 30 min under argon. Reproduced with permission from ref. ${ }^{115}$.

Few ALD approaches have been successfully developed to directly deposit few $\mathrm{MoS}_{2}$ layers. However, post-annealing is often required for obtaining the hexagonal 2D phase. Similarly to graphene, ALET has also been adapted for producing one to few $\mathrm{MoS}_{2}$ layers from crystalline CVD molybdenum sulfide. ${ }^{94,116-118}$ Successive $\mathrm{Cl}$ radical adsorption, which weakens Mo-S bond, and $\mathrm{Ar}^{+}$ion beam desorption lead to the successful layer by layer etching of the TMD (Figure 11a). ${ }^{94,116,117}$ Raman characterization enables monitoring the $\mathrm{MoS}_{2}$ thickness as a function of the ALET cycles. ${ }^{94}$ Precise removal of one monolayer at each full cycle without damage/impurities incorporation is verified (Figure $\mathbf{1 1 b}, \mathbf{c}$ ). Such atomic layer process seems well-suited for device fabrication. Kim et al. ${ }^{116}$ investigate the involved mechanism using Raman and XPS analyses. More complex etching pathway than that of graphene occurs due to the three atomic layer $\mathrm{S}_{(\text {top })}-\mathrm{Mo}_{\text {(middle) }} \mathrm{S}_{\text {(bottom) }}$ arrangement of $\mathrm{MoS}_{2}$. During radical adsorption step, $\mathrm{Cl}$ bonds to the first $\mathrm{S}$ top layer and intercalates through VdW interaction into $\mathrm{S}_{(\text {top) }}-\mathrm{Mo}_{\text {(middle) }}$ bonding. Both interactions weaken the corresponding binding energy, 
i.e. $\mathrm{S}_{\text {(top) }}-\mathrm{Mo}_{\text {(middle) }}, \mathrm{S}_{\text {(bottom) }}-\mathrm{Mo}_{\text {(middle), }}$, favoring the removal of the top $\mathrm{S}$ and Mo layer during $\mathrm{Ar}^{+}$ exposure. Once Mo atoms removed, VdW interactions with the underneath $\mathrm{MoS}_{2}$ layer lower and bottom sulfurs are detached by $\mathrm{Ar}^{+}$ion. The general mechanism is schematized in Figure 11d. No damage of the beneath TMD is observed and its electric properties are preserved as shown using FET device. ${ }^{116}$ Based on remote $\mathrm{O}_{2}$ plasma oxidation, a second ALET approach has been recently introduced. ${ }^{118}$ Under controlled oxidation, meaning at least $5 \mathrm{~min}$ at $200{ }^{\circ} \mathrm{C}$ of $\mathrm{O}_{2}$ plasma exposure, the single top crystalline $\mathrm{MoS}_{2}$ layer is fully converted into amorphous $\mathrm{MoO}_{3}$. The latter is sublimated under UHV annealing at $500{ }^{\circ} \mathrm{C}$. As demonstrated by XPS, sharp interface exists between the obtained monolayered oxide and the underlying TMD layer. It enables precise and uniform removal of one single layer, leaving well-ordered hexagonal $\mathrm{MoS}_{2}$ material without noticeable damage, as evidenced by LEED pattern after ALET cycle (Figure 11e). ${ }^{118}$

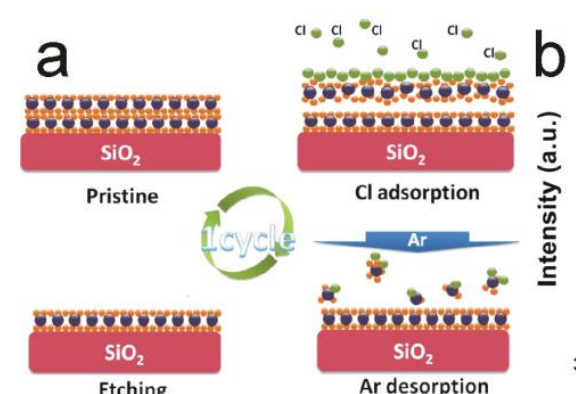

Etching
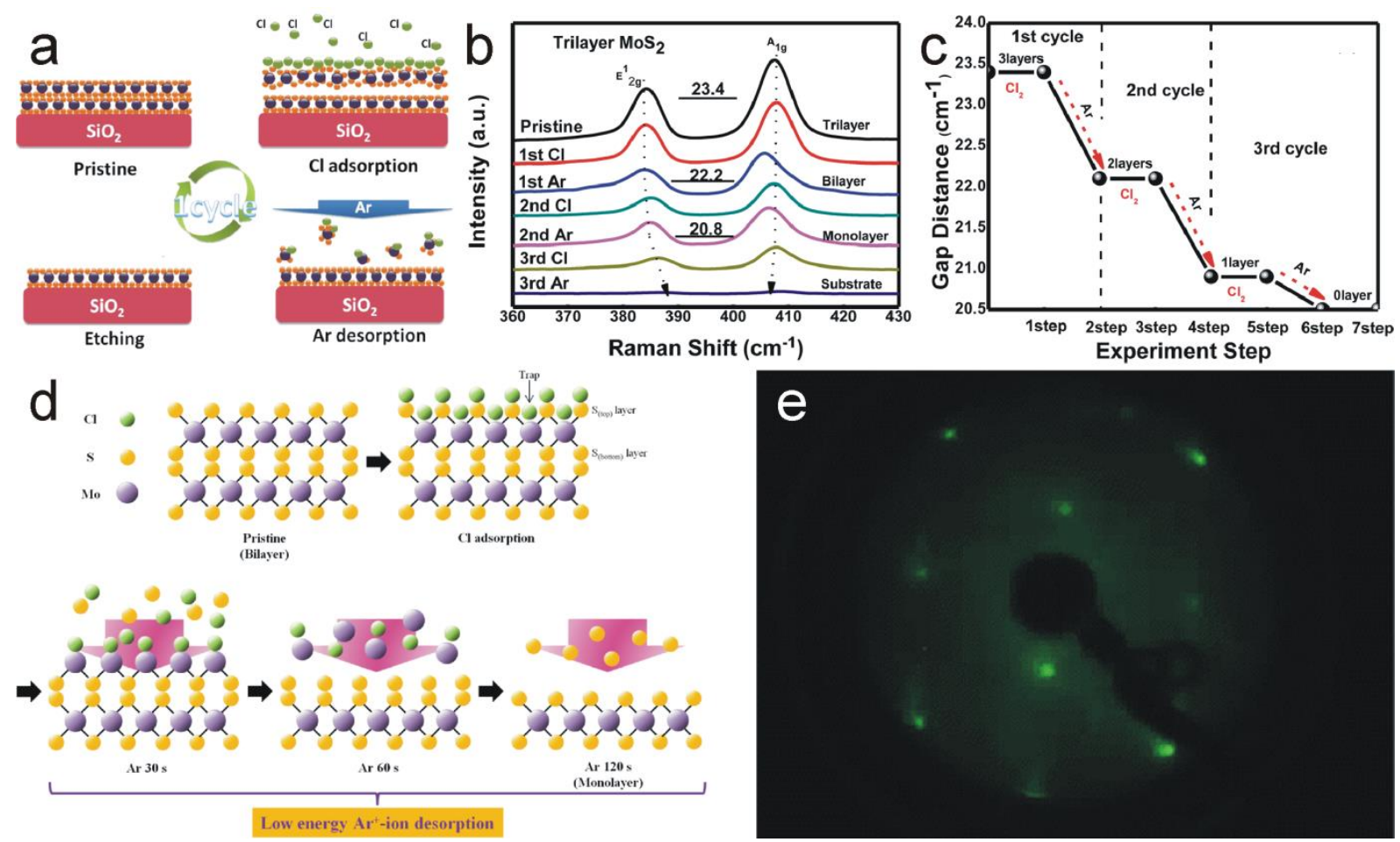

Figure 11. a) Schematic of one ALET cycle based on $\mathrm{Cl}$ radical adsorption and $\mathrm{Ar}^{+}$desorption steps. b) Raman spectra and the corresponding change of gap distance between $E_{2 g}^{1}$ and $A_{1 g}$ bands of a trilayer after each ALET step. Reproduced with permission from ref. ${ }^{94}$. d) Schematic of the proposed ALET mechanism of $\mathrm{MoS}_{2}$ layer. Reproduced with permission from ref. ${ }^{116}$. e) LEED pattern of $\mathrm{MoS}_{2}$ sample after exposure to remote $\mathrm{O}_{2}$ plasma at $200{ }^{\circ} \mathrm{C}$ and further annealing at $500{ }^{\circ} \mathrm{C}$ under UHV. Reproduced with permission from ref. ${ }^{118}$.

Finally, atomic layer techniques are not only used for growing/etching 2D MoX 2 material. Recently, 2D MoSe $e_{2}$ has been doped by Nb using PEALD. Deposition of 1-2 nm Nb${ }_{2} \mathrm{O}_{3}$ on $\mathrm{MoO}_{3}$ with successive selenization leads to $\mathrm{Nb}: \mathrm{MoSe}_{2}$ by $\mathrm{Nb}$ thermal diffusion, indeed. Control of the number of ALD cycles allows fine tuning of the doping concentration. ${ }^{119}$ 


\subsection{Fabrication of $\mathrm{WS}_{2}$ and $\mathrm{WSe}_{2}$}

Tungsten disulfide, a well-known solid lubricant, presents similar hexagonal layered structure and electronic properties than $\mathrm{MoS}_{2}$. Much less studied, its ALD deposition has been reported earlier: in 2004, motivated by its tribological properties, Scharf et al. ${ }^{120}$ realize the first ALD growth, from WF 6 and $\mathrm{H}_{2} \mathrm{~S}$ at $300{ }^{\circ} \mathrm{C}$. Interestingly, this process requires a catalyst that promotes the adsorption of $\mathrm{WF}_{6}$ onto the substrate. Without reaction initiator, no growth is observed in the range of $250-350{ }^{\circ} \mathrm{C}$ on any substrate like $\mathrm{SiO}_{2} / \mathrm{Si}$ wafer or QCM crystal. On the other hand, either ALD deposition of one ZnS monolayer using DiEthylZinc (DEZ) and $\mathrm{H}_{2} \mathrm{~S}$, or use of a single pulse of DEZ permits rapid nucleation of the $\mathrm{WS}_{2}$ film over a wide range of substrates. ${ }^{120,121}$ Indeed, $\mathrm{Zn}$ acts as reducing agent for $\mathrm{WF}_{6}$ favoring its adsorption. When DEZ catalyst is used, QCM measurements demonstrate an overall GPC of 1 $\AA$ A/cycle, although high initial growth rate and GPC lowering after $50 \mathrm{WS}_{2}$ cycles are noted due to, respectively, excess and lack of available Zn. A single DEZ pulse permits restoring the catalyzed growth (Figure 12a). ${ }^{120,121}$ On the contrary, linear relationship between the film thickness and the number of ALD cycles is observed with ZnS layer catalyst; however the GPC is strongly dependent in this case on the underlying substrate. Indeed, the reducing properties of zinc are modulated by the free electron availability of the substrate. ${ }^{121,122}$
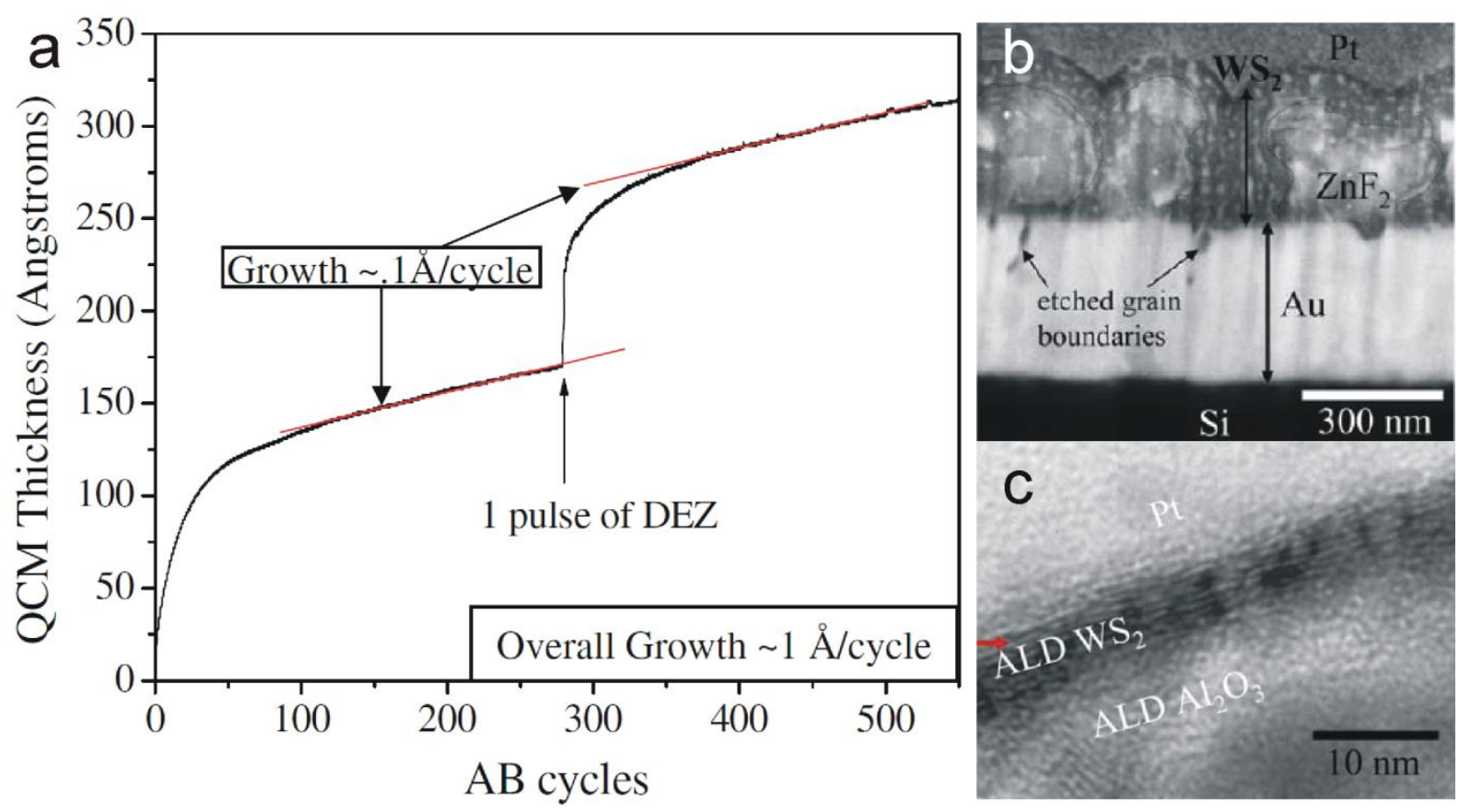

Figure 12. a) Film thickness as a function of the number of ALD cycles using DEZ catalyst. b) Cross-section SEM image of WS coating deposited on gold substrate using DEZ catalyst. c) HRTEM image of $\mathrm{WS}_{2}$ ALD grown on $\mathrm{ALD}^{\mathrm{Al}} \mathrm{O}_{3} / \mathrm{Si}$ support. Reproduced with permission from ref. ${ }^{121}$

As-deposited $\mathrm{WS}_{2}$ film displays crystalline hexagonal phase with strong (002) texture, preferential orientation of the basal planes (oriented perpendicular or parallel to the substrate) depending on the deposition temperature. ${ }^{120,121}$ Raman spectra exhibit the typical signature of the 2D TMDs without 
noticeable change between as-grown and annealed films at $500{ }^{\circ} \mathrm{C}$ under vacuum. ${ }^{120} \mathrm{SEM}$ and TEM characterizations reveal inclusion of $\mathrm{ZnF}_{2}$ cluster into the deposited $\mathrm{WS}_{2}$ layer. In particular, DEZ catalyzed growth on Au leads to formation of large $\mathrm{ZnF}_{2}$ clusters mainly located at the interface (Figure 12b), while $\mathrm{ZnS}$ catalyst produces nanometer sized particles of $\mathrm{ZnF}_{2}$ and small $\mathrm{ZnS}$ clusters, both dispersed along the layer and surrounded by $\mathrm{WS}_{2}$ crystallites. ZnS inclusion disappears with the thickness increase probably due to its consumption. It should be pointed that the released HF during the ALD reaction might etch the substrate like $\mathrm{SiO}_{2}$ and $\mathrm{Au}$. Drastic damages are noted with excess of $\mathrm{Zn}$ as with DEZ catalyst (Figure 12b). This effect might be overcome using thin $\mathrm{Al}_{2} \mathrm{O}_{3}$ layer; layered $\mathrm{WS}_{2}$ without interfacial mixing of $\mathrm{WS}_{2}$ and $\mathrm{Al}_{2} \mathrm{O}_{3}$ is observed in Figure 12c. ${ }^{121}$ Investigation of the tribological behavior of the deposited films reveals very low friction and wear coefficients, low torque value close to that of $\mathrm{MoS}_{2}$ and no tribooxidation under dry atmosphere, while near full oxidation of the film occurs in air. ${ }^{121,122}$

Later on, Delabies et al. ${ }^{123}$ investigate and identify other reducing agents like $\mathrm{Si}$ layer and $\mathrm{H}_{2}$ plasma to grow nanocrystalline $\mathrm{WS}_{2}$. Indeed, partial reduction is required to form $\mathrm{WS}_{2}$ (+IV oxidation state of W) from $\mathrm{WF}_{6}(+\mathrm{VI}$ state). On the one hand, thin sacrificial layers of $\mathrm{H}$-passivated $\mathrm{Si}$ formed on $\mathrm{Al}_{2} \mathrm{O}_{3} / \mathrm{Si}(100)$ proves acting as nucleation promoter for growth at $450{ }^{\circ} \mathrm{C}$. Under release of $\mathrm{SiF}_{4}, \mathrm{Si}$ reduces $\mathrm{WF}_{6}$ into metallic tungsten that can be consecutively oxidized and sulfurized by the following $\mathrm{H}_{2} \mathrm{~S}$ pulse. Maximum of $6 \mathrm{~nm}$ of Si can completely react with the halide compound and thus $\mathrm{Si}-$ catalyzed ALD process at $450{ }^{\circ} \mathrm{C}$ is self-limiting to the growth of six $\mathrm{WS}_{2}$ layers as further $\mathrm{W}$ content cannot be fully sulfurized. On the other hand, PEALD using $\mathrm{H}_{2}$ plasma as reducing agent leads to linear growth with an average GPC of $0.02 \mathrm{~nm} / \mathrm{cycle}$ at $300-450{ }^{\circ} \mathrm{C}$. Mild plasma conditions (power and exposure time) are required to deposit reproducible stoichiometric films without substrate blistering. Polycrystalline layered films with small grains are effectively fabricated with both reducing agents, as evidenced by Raman and TEM characterizations. Similarly to Zn-catalyzed ALD, preferential basal plane orientation depends on the PEALD deposition temperature (Figure 13). ${ }^{123}$ Recently, the reaction and especially the redox reaction mechanism involved during the PEALD process have been investigated in details. ${ }^{124}$ Briefly, $\mathrm{WF}_{6}$ adsorbs onto sulfur reactive species such as $\mathrm{S}$ surface atoms and -SH groups, that most probably exist only at the layer edges, even though adsorption onto the basal planes likely occurs via VdW interactions and S anchoring defects. In absence of reducing agent, no growth occurs as $\mathrm{W}$ remains in its initial oxidation state. $\mathrm{H}_{2}$ plasma permits the reduction of W from its $+\mathrm{VI}$ to 0 oxidation state, or at least to lower intermediate oxidation states. However plasma conditions have to be carefully chosen to reduce only species at the extreme surface and avoid damaging the underneath $W_{2}$ film or even the substrate. Finally, $\mathrm{H}_{2} \mathrm{~S}$ oxidizes $\mathrm{W}$ into its +IV state and creates W-S bonds, and this only at or near the surface as $\mathrm{H}_{2} \mathrm{~S}$ does not diffuse into the W layer at low temperature. To sum up, $\mathrm{WS}_{2}$ is formed by the successive adsorption, reduction and oxidation 
reactions of surface $\mathrm{W}$ species. The deposition temperature influencing the kinetic of the $\mathrm{W}$ oxidation reaction, loose of stoichiometry is observed at low temperature $\left(250^{\circ} \mathrm{C}\right)$. Low PEALD GPC can be attributed to the lack of anchoring sites during the $\mathrm{WF}_{6}$ pulses. ${ }^{124}$

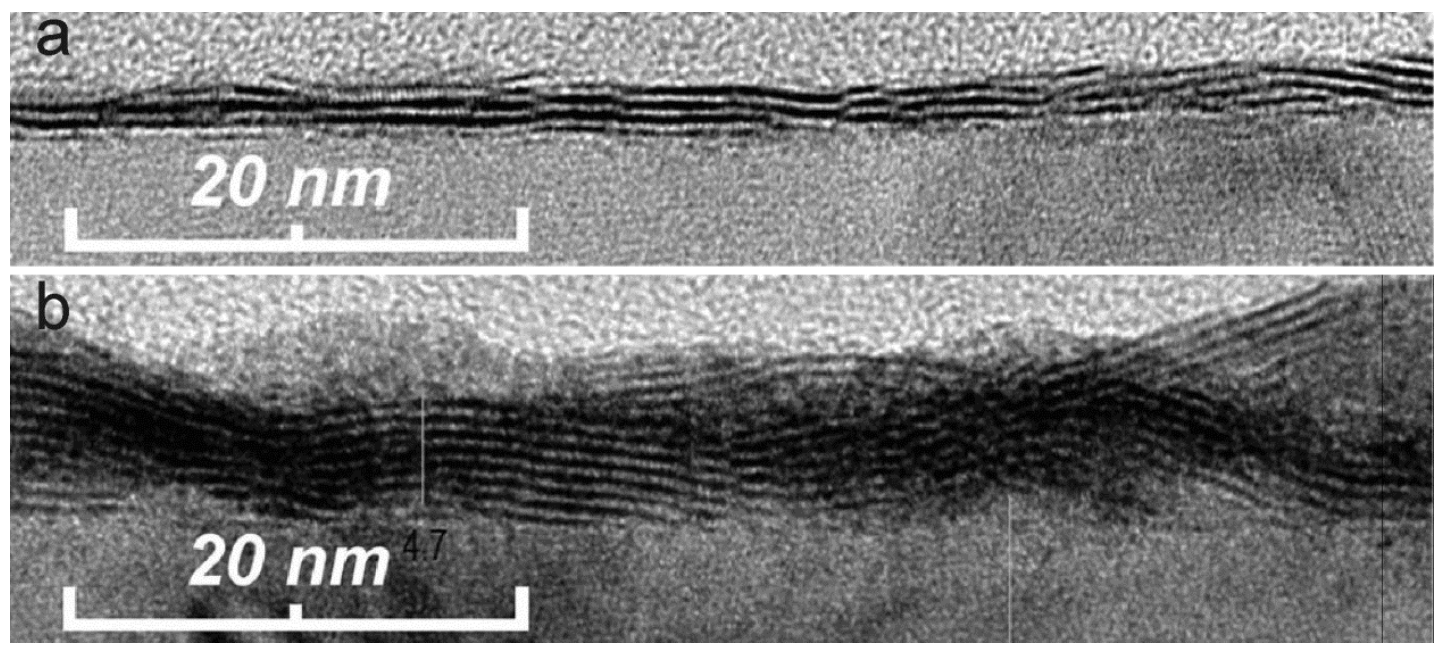

Figure 13. Cross section TEM images of $W S_{2}$ layers PEALD deposited from $W F_{6}, \mathrm{H}_{2}$ plasma and $\mathrm{H}_{2} \mathrm{~S}$ on crystalline $\mathrm{Al}_{2} \mathrm{O}_{3}$ at a) 300 and b) $450{ }^{\circ} \mathrm{C}$ demonstrate preferential orientation of the basal planes parallel to the substrate at $300{ }^{\circ} \mathrm{C}$ and more random orientation at $450{ }^{\circ} \mathrm{C}$. Reproduced with permission from ref. ${ }^{123}$.

One can mention that use of tungsten chloride $\left(\mathrm{WCl}_{5}\right)$, instead of $\mathrm{WF}_{6}$, permits the ALD deposition of well-crystallized $2 \mathrm{H}-\mathrm{WS}_{2}$ (hexagonal phase) layers, without catalyst at $390^{\circ} \mathrm{C}$ and with a $\mathrm{GPC}$ of 0.125 $\mathrm{nm} /$ cycle. This process permits fabricating 2D heterostructures, as described in section $2.4{ }^{125}$

Alternatively, ALD process based on the reaction of $\mathrm{W}(\mathrm{CO})_{6}$ with $\mathrm{H}_{2} \mathrm{~S}$ is developed to avoid halide precursor and thus corrosive by-products like HF. ${ }^{126,127}$ Deposition, at $400{ }^{\circ} \mathrm{C}$, of ultra-lubricant $\mathrm{WS}_{2}$ films is reported, with a GPC of $0.36 \mathrm{~nm} /$ cycle, on $\mathrm{Si}(100)$ with native oxide and on $\mathrm{ZnS} / \mathrm{Si}(100)$. Both as-deposited films are polycrystalline with (002) and (101) preferential orientation, although denser film with lower hole defect density, stronger adhesion and favored (002) orientation is obtained on ZnS intermediate layer. ${ }^{126}$ In parallel, in-situ QCM characterization shows no growth below $150{ }^{\circ} \mathrm{C}$, while linear mass gain with the temperature is visible above $205^{\circ} \mathrm{C} .{ }^{127}$ The ALD window is determined between 175 and $205{ }^{\circ} \mathrm{C} ; \mathrm{W}(\mathrm{CO})_{6}$ decomposition likely occurring above. Therefore, one can hypothesize that the previous reported films probably result more from precursor decomposition than from ALD reaction, which could explain the high GPC. In addition to QCM analysis, Nandi et al. ${ }^{127}$ investigate the reaction mechanism using in-situ FTIR spectroscopy and residual gas analysis. Completion and saturation of both half-reactions is evidenced by the reproducible appearance and full disappearance of $\mathrm{C}=\mathrm{O}$ and $\mathrm{S}-\mathrm{H}$ bands after, respectively, $\mathrm{W}(\mathrm{CO})_{6}$ and $\mathrm{H}_{2} \mathrm{~S}$ pulse. $\mathrm{CO}$ and $\mathrm{H}_{2}$ are the only by-products and most of the carbonyl groups are released during the $\mathrm{W}$ precursor exposure. The obtained films appear suitable as anode material for Li-batteries, the overall cell capacity being enhanced using a carbon nanotube scaffold. Finally, it should be noted that amorphous films are 
obtained in this case, on the contrary to deposition at $400{ }^{\circ} \mathrm{C}$ that produces polycrystalline layers. ${ }^{126,127}$

In summary, few $\mathrm{WS}_{2} \mathrm{ALD} / \mathrm{PEALD}$ processes have been developed, although $\mathrm{WS}_{2}$ is a highly promising 2D material. Only three W ALD precursors are described up to now, all reacted with $\mathrm{H}_{2} \mathrm{~S}$ as unique $\mathrm{S}$ source and complex chemistry has been identified depending on the $\mathrm{W}$ reactant. Obtaining of monocrystalline as-grown layers being not yet reported, challenges especially in terms of crystallinity, and ALD reactants remain.

In parallel to direct ALD growth, sulfidation of ALD $W_{3}$ thin films (see part 3.2) is also studied. In particular, tungsten disulfide sheets displaying hexagonal lattice are obtained by treatment under $\mathrm{Ar} / \mathrm{H}_{2} \mathrm{~S}$ atmosphere of PEALD $\mathrm{WO}_{3}$ layers and implemented into FET devices. ${ }^{128}$ Gas sensing properties of sulfurized $\mathrm{WS}_{2}$ layers on $\mathrm{SiO}_{2} / \mathrm{Si}$ are also tested and an enhanced selectivity toward $\mathrm{NO}_{2}$ is noted when decorated with $\mathrm{Ag}$ nanowires. ${ }^{129} \mathrm{~A}$ new desoxidizer, $\mathrm{CS}_{4}$, which is less toxic and cheaper than $\mathrm{S}$ vapor and $\mathrm{H}_{2} \mathrm{~S}$, is employed to form Al:WS $\mathrm{W}_{2}$ with tuned optical properties from Al: $\mathrm{WO}_{3}$ film. ${ }^{130}$

It should also be emphasized that based on subsequent sulfurization process, mix $\mathrm{Mo}_{1-x} \mathrm{~W}_{\mathrm{x}} \mathrm{S}_{2}$ has been fabricated from multilayered $\mathrm{MoO}_{x}$ and $\mathrm{WO}_{3}$ structure. Briefly, $\mathrm{MoO}_{3}$ thin layer is first deposited from $\mathrm{Mo}(\mathrm{CO})_{6}$ and $\mathrm{O}_{2}$ plasma for discarding nucleation delay. Then super ALD cycles ( $\mathrm{n}$ $\mathrm{MoO}_{x} / \mathrm{m} \mathrm{WO}_{3}$ cycles) are performed from $\mathrm{Mo}(\mathrm{CO})_{6}, \mathrm{WH}_{2}(\mathrm{iPrCp})_{2}$ and $\mathrm{O}_{2}$. The consecutive two-step sulfurization leads to the mix TMD without oxide contaminant. Controlled vertical composition and even controlled gradient is achievable by tuning of the cycle number of each oxide during the supercycle. $^{131}$

Less known than $\mathrm{WS}_{2}$, tungsten diselenide is another stable 2D TMDs, which has also been ALD deposited. In 2016, two groups report in parallel the first deposition of $\mathrm{WSe}_{2}$ using different approaches. ${ }^{96,132}$ On the one hand, thermal ALD formation at $390{ }^{\circ} \mathrm{C}$ of large continuous WSe $\mathrm{e}_{2}$ film on $\mathrm{SiO}_{2} / \mathrm{Si}$ is demonstrated from $\mathrm{WCl}_{5}$ and $\mathrm{H}_{2} \mathrm{Se} .{ }^{132}$ Well-crystallized film displaying layered structure with similar quality than exfoliated or CVD films are obtained and integrated into FET devices. On the other hand, self-limiting layer synthesis of $\mathrm{WSe}_{2}$ using $\mathrm{WCl}_{6}$ reacted with DiEthyl Selenide (DESe) is investigated at relatively high temperature $\left(600-800{ }^{\circ} \mathrm{C}\right) .{ }^{96}$ Reduction of $\mathrm{WCl}_{6}$ and removal of chloride is hydrogen assisted during the DESe pulse. As for $\mathrm{MoS}_{2}$, the thickness of the deposited layer is temperature determined. Five, three and one well-crystallized layers are fabricated, respectively, at 600,700 and $800{ }^{\circ} \mathrm{C}$, over $8 \mathrm{~cm}^{2} \mathrm{SiO}_{2}$ support with wafer-scale uniformity. Growth saturation occurs after 100 cycles, meaning no further increase of thickness with additional cycles. The WSe ${ }_{2} S L S$ is based on the chemical inertness of TMD surface and on the favored desorption at high temperature of tungsten precursor that might only physically adsorb. The synthesized layers are then integrated 
into back-gated FET and demonstrate excellent p-type behavior, promising for future electronic device application.

ALD fabrication of $\mathrm{WSe}_{2}$ is at its beginning but it has already demonstrated high potentiality with obtaining of well-crystallized layers. However, as for $W_{2}$, few $W$ sources are employed, and the involved chemistry is up to now rather poor. Further developments, especially regarding the precursors and chemistry are still needed. On the other side, SLS appears as a promising atomic layer technique to fabricate large-scale 2D TMDs.

\subsection{Fabrication of other layered chalcogenides}

Besides Mo and W TMDs, various metal chalcogenides, in particular metal sulfides, have been synthesized using ALD. More than 300 papers, many of them published before the graphene isolation, can currently be found in the literature. However, most of the ALD deposited materials are not 2D layered structures. Indeed, among them only $\mathrm{SnS}_{\mathrm{x}}$ (with $\mathrm{x}=1$ or 2 ), ${ }^{88,133-144} \mathrm{GeS}^{88} \gamma-\mathrm{MnS}^{89}$ $\mathrm{TiS}_{2},{ }^{145,146} \mathrm{GaS}^{90,147} \gamma$-InSe, ${ }^{93} \mathrm{Bi}_{2} \mathrm{Te}_{3},{ }^{148-152} \mathrm{Bi}_{2} \mathrm{Se}_{3},{ }^{153} \mathrm{Bi}_{2} \mathrm{~S}_{3},{ }^{154} \mathrm{Sb}_{2} \mathrm{Te}_{3},{ }^{148} \mathrm{Sb}_{2} \mathrm{Se}_{3}{ }^{93}$ and the less known $\beta$ $\mathrm{NiS}^{91}$ and $\mathrm{FeS}_{x}{ }^{92}$ display layered rhombohedral, orthorhombic or hexagonal crystalline phase and are

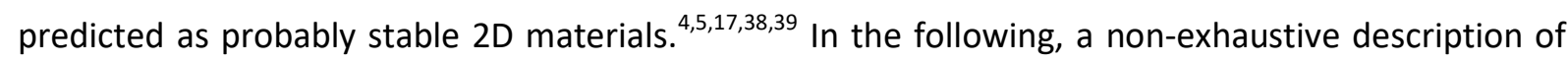
the ALD processes and precursors used for these 2D materials will briefly be given. Table 2 summarizes the main ALD conditions as well as the eventual applications of each 2D material.

After the TMDs, SnS and $\mathrm{SnS}_{2}$ are the most investigated layered metal chalcogenides. Tin monosulfide has been first fabricated from tin (II) 2,4-pentanedionate ( $\mathrm{Sn}(\mathrm{acac})_{2}$ ) reacted with $\mathrm{H}_{2} \mathrm{~S}$. Wide ALD window from 125 to $225^{\circ} \mathrm{C}$ with a GPC of $0.23 \AA$ A/cycle is reported. ${ }^{134}$ Later on, Bilousov et al. ${ }^{133}$ demonstrate the influence of the ALD parameters on the crystallinity: long $\mathrm{H}_{2} \mathrm{~S}$ exposure reveals benefiting the formation of the cubic SnS phase while short pulse as well as deposition temperature favors the orthorhombic phase, which is the $2 \mathrm{D}$ form of SnS. Other tin precursors, bis $\left(\mathrm{N}, \mathrm{N}^{\prime}\right.$ diisopropylacetamidinato) tin (II) $\left(\mathrm{Sn}(\mathrm{amd})_{2}\right)^{88,137}$ and $\mathrm{N}^{2}, \mathrm{~N}^{3}$-di-tert-butylbutane-2,3-diamine tin (II), ${ }^{88}$ reacted with $\mathrm{H}_{2} \mathrm{~S}$, are also reported. Both reactants display single evaporation step without residue ${ }^{88}$ and are effective for conformal ALD of polycrystalline SnS at low temperature $\left(<200{ }^{\circ} \mathrm{C}\right) .{ }^{88,137}$ Precursors containing Sn atom under +ll oxidation state mitigate the formation of other sulfides like $\mathrm{SnS}_{2}$ and $\mathrm{Sn}_{2} \mathrm{~S}_{3} \cdot{ }^{137} \mathrm{SnS}$ and $\mathrm{Sb}: \mathrm{SnS}$ based solar cells are successfully fabricated from $\mathrm{Sn}(\mathrm{amd})_{2}$ and $\mathrm{H}_{2} \mathrm{~S}$ indeed. ${ }^{135,139}$ On the other side, layered $\mathrm{SnS}_{2}$ films are obtained from $\mathrm{Sn}$ (IV) reactants like tetrakis (dimethylamino) tin (TDMASn) ${ }^{140,142}$ and tin acetate $\left(\mathrm{Sn}(\mathrm{OAc})_{4}\right) .{ }^{144}$ From TDMASn and $\mathrm{H}_{2} \mathrm{~S}$, amorphous, hexagonal $\mathrm{SnS}_{2}$ and orthorhombic $\mathrm{SnS}$ can be obtained depending on the deposition temperature. At $140-150{ }^{\circ} \mathrm{C}$, smooth and well-covered polycrystalline hexagonal $\mathrm{SnS}_{2}$ films are fabricated with a GPC ranging from 0.87 to $0.64 \AA$ A/cycle. ${ }^{140}$ Post annealing under $\mathrm{H}_{2} \mathrm{~S}$ increases the 
layer crystallinity. HRTEM reveals atomic planes, with S-Sn-S triatomic planar arrangement, parallel to the substrate (Figure 14), indeed. Disulfide stoichiometry is confirmed by XPS despite the presence of a small amount of SnS. ${ }^{141}$ Above $160{ }^{\circ} \mathrm{C}$, XPS endorses the formation of monosulfide rather than $\mathrm{SnS}_{2}{ }^{140}$ even though co-existence of both tin sulfides may occur. ${ }^{142}$ RTA treatment under $\mathrm{H}_{2}$ at 330$360{ }^{\circ} \mathrm{C}$ may overcome this issue and lead to single orthorhombic SnS. ${ }^{142}$ FET devices are fabricated using $\mathrm{SnS}_{2}$ channel sandwiched between $\mathrm{ZrO}_{2}$. Typical layered structure is noted after ALD at $150{ }^{\circ} \mathrm{C}$ followed by annealing under sulfur atmosphere at $300{ }^{\circ} \mathrm{C} .{ }^{143}$ Finally Mattinen et al. ${ }^{144}$ use $\mathrm{Sn}(\mathrm{OAc})_{4}$ for depositing two to ten layers of $\mathrm{SnS}_{2}$. Stoichiometric, smooth amorphous film is obtained at $150{ }^{\circ} \mathrm{C}$ with a GPC of $0.17 \AA$ A/cycle. Post-annealing at $250{ }^{\circ} \mathrm{C}$ under $\mathrm{H}_{2} \mathrm{~S} / \mathrm{N}_{2}$ allows its crystallization. This layer is used as seed for further ALD cycles, allowing direct deposition of crystalline $\mathrm{SnS}_{2}$. To sum up, various $\mathrm{Sn}$ precursors, all reacting with $\mathrm{H}_{2} \mathrm{~S}$, are employed for ALD of $\mathrm{SnS}_{\mathrm{x}}$. Depending on the ALD conditions and post-treatments, films made of SnS under different crystal phases and $\mathrm{SnS}_{2}$ can selectively be obtained.

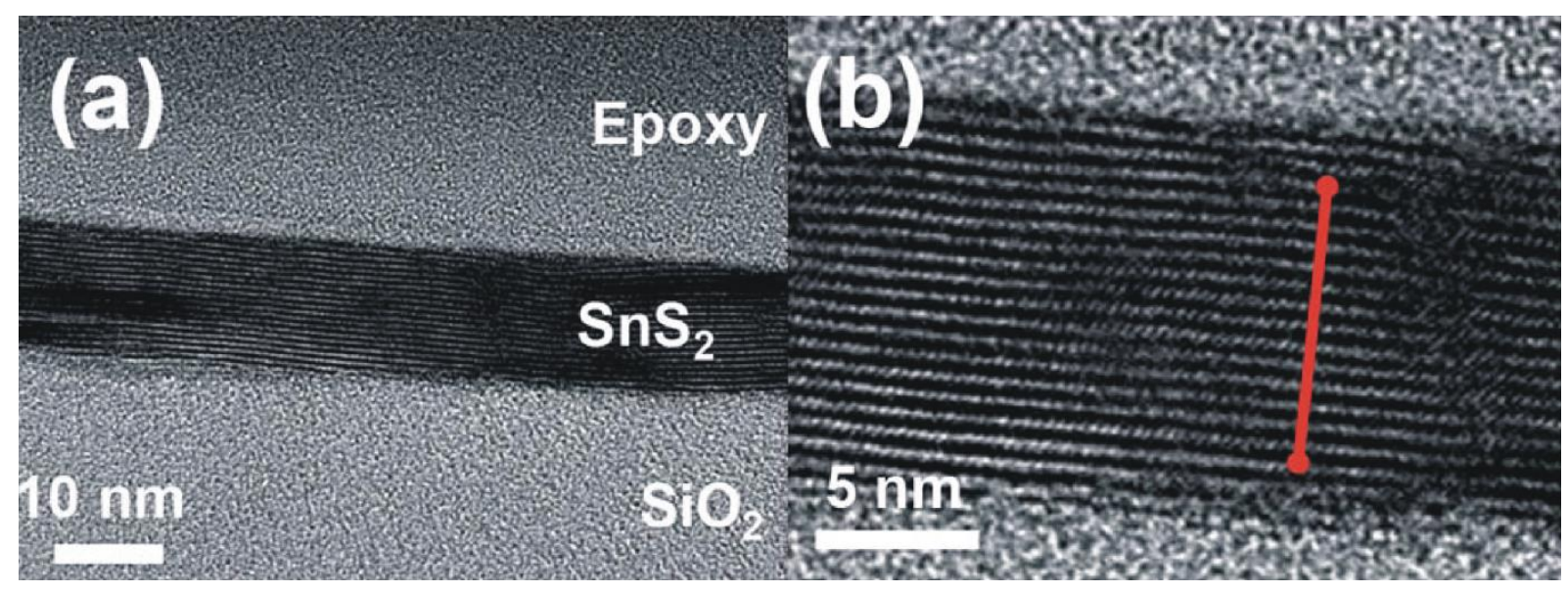

Figure 14. a,b) TEM images of $\mathrm{SnS}_{2}$ film fabricated from TDMASn reacted with $\mathrm{H}_{2} \mathrm{~S}$ and after annealing at $300{ }^{\circ} \mathrm{C}$. Reproduced with permission from Ref. ${ }^{141}$

Regarding the other layered metal sulfides, three classes of metal source are identified, depending on the desired material, and only $\mathrm{H}_{2} \mathrm{~S}$ is reported as co-reactant. Briefly, metal amines are employed for $\mathrm{GeS}^{88} \mathrm{GaS}^{90}$ and $\mathrm{FeS}_{\mathrm{x}}{ }^{92}$ while organometallics like bis(ethylcyclopentadienyl) manganese ( $\left.\mathrm{Mn}(\mathrm{EtCP})_{2}\right)$, bis(2,2,6,6-tetramethylheptane-3,5-dionate) nickel(II) ( $\left.\mathrm{Ni}(\text { thd })_{2}\right)$ and Bi(thd) $)_{3}$ allow the deposition of respectively, $\gamma-\mathrm{MnS}^{89}{ }^{89}-\mathrm{NiS}^{91}$-applied to Li-ion battery and dye sensitive solar cellsand $\mathrm{Bi}_{2} \mathrm{~S}_{3} .{ }^{154}$ These processes are performed at low to mid temperature $\left(100-250{ }^{\circ} \mathrm{C}\right)$, expected for GeS ALD taking place near room temperature $\left(50-75{ }^{\circ} \mathrm{C}\right)$. Indeed, in this case, desorption phenomenon occurs above $150{ }^{\circ} \mathrm{C} .{ }^{88}$ Finally, the metal halide, $\mathrm{TiCl}_{4}$, is reacted with $\mathrm{H}_{2} \mathrm{~S}$ at different temperature ranges for $\mathrm{TiS}_{2}$ film deposition. $\mathrm{TiCl}_{4}$ being thermally stable, one can note the existence of two ALD windows at low and mid temperature range; one leading to better crystallinity and the 
other to higher GPC. A first ALD window is determined between 400 and $500{ }^{\circ} \mathrm{C}$, corresponding to a growth of 0.15-0.2 $\AA$ /cycle. Polycrystalline hexagonal $\mathrm{TiS}_{2}$ layers are grown on various substrates like soda lime, TiN and Pd as well as (001) oriented films on ZnS and Pt supports. ${ }^{146}$ On the other hand, saturated growth with a rate of $0.5 \AA$ /cycle is identified in the range of $125-200{ }^{\circ} \mathrm{C}$ by in situ QCM. The as-deposited film reveals in this case poorly crystalline. ${ }^{145}$

Finally, few metal $(\mathrm{Bi}, \mathrm{Sb}, \mathrm{In})$ tellurides and selenides have been already elaborated by ALD. The involved processes are essentially based on the reaction between the corresponding metal chloride and either (trimethylsilyl) or bis(triethylsilyl) complexes of tellurium and selenium. In particular, these alkylsilyl compounds, developed by the group of Leskelä, display a clean single evaporation step without residue and are effective Se and Te sources for a large range of chalcogenide materials. ${ }^{148,149}$ To overcome issues related to the use of $\mathrm{BiCl}_{3}$ like its high vaporization temperature $\left(>140{ }^{\circ} \mathrm{C}\right)$ and unwanted halide contamination, homoleptic bismuth amides $\mathrm{Bi}\left(\mathrm{NR}^{1} \mathrm{R}^{2}\right)_{3}$ (with $\mathrm{R}^{1}, \mathrm{R}^{2}=\mathrm{Me}$ or $\mathrm{Et}$ ) and cyclo-dibismadiazane $\left[\left(\mathrm{Me}_{3} \mathrm{Si}\right)_{2} \mathrm{NBi}-\mu \text {-NSiMe }\right]_{2}$ are tested in ALD with $\left(\left(\mathrm{Et}_{3} \mathrm{Si}\right)_{2} \mathrm{Te}\right.$. They enable growth of crystalline $\mathrm{Bi}_{2} \mathrm{Te}_{3}$ films on $\mathrm{SiO}_{2}$ and thus appear effective potential substitute to $\mathrm{BCl}_{3}{ }^{152}$ Nonetheless, $\mathrm{H}_{2} \mathrm{Se}$ is also employed as an alternative selenium source to deposit successive layers of $\mathrm{Sb}_{2} \mathrm{Se}_{3}$ and $\gamma$-InSe from their respective chlorine precursors. ${ }^{93}$

This brief introduction to probably stable 2D metal chalcogenides highlights that the involved chemistry remains still limited with on the one side $\mathrm{H}_{2} \mathrm{~S} / \mathrm{H}_{2} \mathrm{Se}$ based process and on the other side the novel alkylsilyl compounds of Te and Se based ALD. However, the materials are generally fabricated at relatively moderate temperature and are often crystalline as-deposited. Control of the crystal phase via the ALD parameters is also available in certain cases.

\subsection{Layered metal dichalcogenide heterostructures by ALD}

As it demonstrates capable for depositing 2D materials, ALD might appear suited for realizing VdW heterostructures. However, inertness of the basal planes of 2D materials should be taken into account. It may lead to lack of anchors inducing difficulties of nucleation. For instance, coating of well-graphitized carbon materials without functionalization is challenging as nucleation delay, island growth and even no growth are reported. ${ }^{155}$ Zheng et al. ${ }^{156}$ successfully ALD deposit layered $\mathrm{Sb}_{2} \mathrm{Te}_{3}$ on CVD grown graphene, from $\mathrm{SbCl}_{3}$ and $\left(\mathrm{Me}_{3} \mathrm{Si}\right)_{2} \mathrm{Te}$. To create active sites, $\left(\mathrm{Me}_{3} \mathrm{Si}\right)_{2} \mathrm{Te}$ is previously physically adsorbed on the graphene. Despite Volmer-Weber growth mode, inherent to the process, well crystallized $24 \mathrm{~nm}$ thick $\mathrm{Sb}_{2} \mathrm{Te}_{3}$ layer, with lattice planes parallel to the graphene ones, is fabricated at $70{ }^{\circ} \mathrm{C}$ on the top of graphene without formation of interface layer or introduction of defects (Figure 15a). The obtained $\mathrm{Sb}_{2} \mathrm{Te}_{3}$ layer displays enhanced thermoelectric properties compared to ones deposited on Si wafer. Indeed, the metal chalcogenide seems preserve from 
oxidation, probably due to its better crystal quality on such carbon support compared on $\mathrm{Si}^{156} \mathrm{Few}$ layered metal dichalcogenide heterostructures entirely fabricated using ALD are also reported. In particular, $\mathrm{Sb}_{2} \mathrm{Te}_{3}$ layers are stacked with $\mathrm{Bi}_{2} \mathrm{Te}_{3}{ }^{157-159}$ From trimethylsilyl telluride reacting with the corresponding metal chloride, thermoelectric layers are alternately grown by ALD. Having a better coverage than $\mathrm{Sb}_{2} \mathrm{Te}_{3}$, deposition of rhombohedral $\mathrm{Bi}_{2} \mathrm{Te}_{3}$ on $\mathrm{Si}$ wafer with native oxide is first realized at $165-170{ }^{\circ} \mathrm{C}$. Owing to its layered structure, no dangling bond is expected on $\mathrm{Bi}_{2} \mathrm{Te}_{3}$. To create anchors for the subsequent $\mathrm{Sb}_{2} \mathrm{Te}_{3}$ growth (at $65-70^{\circ} \mathrm{C}$ ), different strategies are envisaged. In particular, initial long $\mathrm{SbCl}_{3}$ pulses enable complete primary surface reaction and thus subsequent full coverage of the second material. ${ }^{158}$ Three stacking of $\mathrm{Bi}_{2} \mathrm{Te}_{3} / \mathrm{Sb}_{2} \mathrm{Te}_{3}$ are successfully demonstrated. HRTEM reveals local epitaxy between both polycrystalline metal tellurides without visible interface (Figure 15b). ${ }^{159}$ In 2017, fabrication of $\mathrm{p}$-n diodes is reported using stack of $\gamma$-InSe and $\mathrm{Sb}_{2} \mathrm{Se}_{3}$. While InSe crystallizes under various polymorphs, only its $\gamma$-phase, which consists in stacked hexagonal layers, can be considered as $2 \mathrm{D}$ material. Its effective ALD deposition from $\mathrm{InCl}_{3}$ reacted with $\mathrm{H}_{2} \mathrm{Se}$ is confirmed by XRD. ${ }^{93}$

Finally, $\mathrm{WS}_{2} / \mathrm{SnS} 2 \mathrm{D}$ heterostructures on $\mathrm{SiO}_{2} / \mathrm{Si}$ are effectively produced by alternating ALD of $\mathrm{WS}_{2}$ and $\mathrm{SnS}$ both at $390^{\circ} \mathrm{C}$. HRTEM investigation evidences the stacking of the two layered materials, as shown in Figure $15 \mathrm{c}, \mathrm{d}$. An angle of $15^{\circ}$ between their c axis is noted because of their different crystal structures and thus lattice mismatch. This misalignment causes a noticeable decrease of hole mobility of SnS as evaluated using back-gated transistor devices. ${ }^{125}$ Therefore, $2 \mathrm{D}$ heterostructures seem more promising for electronic application when they display similar crystalline structure. 


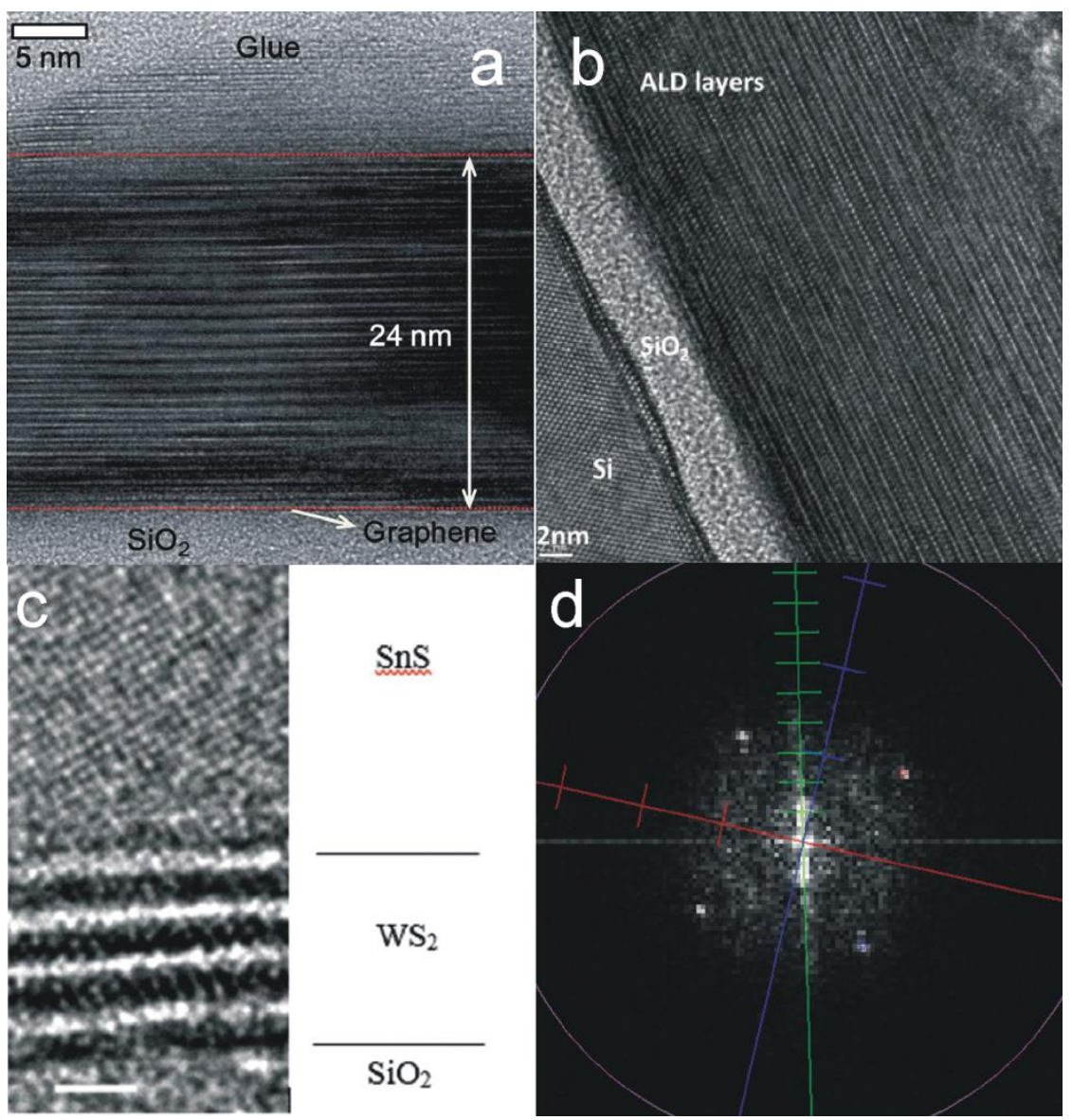

Figure 15. a) Cross-section HRTEM image of $\mathrm{Sb}_{2} \mathrm{Te}_{3}$ film grown on graphene/SiO ${ }_{2}$. Reproduced with permission from ref. ${ }^{156}$ b) Cross-section HRTEM image of $\mathrm{ALD} \mathrm{Sb}_{2} \mathrm{Te}_{3} / \mathrm{Bi}_{2} \mathrm{Te}_{3}$ layers stack on $\mathrm{SiO}_{2}$. Reproduced with permission from ref. ${ }^{157} \mathrm{c}$ ) Crosssection HRTEM image of SnS/WS $\mathrm{W}_{2}$ interface and d) the corresponding FFT. The scale marker represents $1 \mathrm{~nm}$. The interlayer spacing of $W_{2}$ is represented in green, the $c^{*}$ and $b^{*}$ axes of SnS are respectively in blue and red. Reproduced with permission from ref. ${ }^{125}$ 
Table 2. Overview of the reported ALD processes on stable and probably stable metal dichalcogenides and their respective applications. Where $\mathrm{T}$ is used for deposition temperature, SiO $\mathrm{S}_{2} \mathrm{Si}$ for $\mathrm{SiO}_{2}$ coated $\mathrm{Si}$, QCM refers to the quartz crystal used for QCM, and (SW)CNT and CFP mean, respectively, (single-walled) carbon nanotubes and carbon fibre paper and ITO (FTO) is used for Indium tin oxide (fluorine doped tin oxide). ALD window is highlighted using *.

\begin{tabular}{|c|c|c|c|c|c|c|c|c|}
\hline Material & Technique & Reactants & Substrate & $\begin{array}{c}\text { Operating } \\
\text { temperature }\end{array}$ & Post-treatment & Crystallinity & Application & Ref. \\
\hline \multirow{15}{*}{$\mathrm{MoS}_{2}$} & SLS & \multirow{6}{*}{$\mathrm{MoCl}_{5} / \mathrm{H}_{2} \mathrm{~S}$} & $\mathrm{SiO}_{2} / \mathrm{Si}$, WSe $\mathrm{Wlakes}_{2}$ & $\begin{array}{l}500^{\circ} \mathrm{C}(3 \mathrm{~L}) \\
700^{\circ} \mathrm{C}(2 \mathrm{~L}) \\
900^{\circ} \mathrm{C}(1 \mathrm{~L})\end{array}$ & None & polycrystalline & FET, p-n diode & 95 \\
\hline & \multirow{14}{*}{ ALD } & & $\mathrm{Al}_{2} \mathrm{O}_{3}(0001)$ & $300^{\circ} \mathrm{C}$ & $\begin{array}{l}800^{\circ} \mathrm{C} \text { for } 30 \mathrm{~min} \\
\text { in } \mathrm{S} \mathrm{atm}\end{array}$ & Well-crystallized, hexagonal & - & 100 \\
\hline & & & $\mathrm{SiO}_{2} / \mathrm{Si}$ & $330-450^{\circ} \mathrm{C}$ & None & Well-crystallized, hexagonal & FET & 101 \\
\hline & & & $300 \mathrm{~nm} \mathrm{SiO} / 2 / \mathrm{Si}(100)$ & 450 & None & Well-crystallized, hexagonal & FET & 102 \\
\hline & & & $\mathrm{Si}, \mathrm{Al}_{2} \mathrm{O}_{3}$ & $420-490$ & None & $\begin{array}{c}\text { Nanocrystalline, size function } \\
\text { of } \mathrm{T} \\
430^{\circ} \mathrm{C} \leq \mathrm{T} \geq 470^{\circ} \mathrm{C}: \mathrm{h}-\mathrm{MoS}_{2} \\
\text { (0002) orientated }\end{array}$ & - & 103 \\
\hline & & & $\mathrm{SiO}_{2} / \mathrm{Si}$ (patterned), quartz & $375,475^{\circ} \mathrm{C}$ & $\begin{array}{c}600-900^{\circ} \mathrm{C} \text { for } 30 \\
\text { min in either } \mathrm{S} \text { atm } \\
\text { or } \mathrm{H}_{2} \mathrm{~S}\end{array}$ & $\begin{array}{l}\text { Small crystallites with basal } \\
\text { planes having preferential } \\
\text { orientation // substrate }\end{array}$ & - & 104 \\
\hline & & $\mathrm{Mo}(\text { thd })_{3} / \mathrm{H}_{2} \mathrm{~S}$ & $\begin{array}{l}\mathrm{SiO}_{2} / \mathrm{Si} \text {, soda lime glass, } \mathrm{ALD} \mathrm{Al}_{2} \mathrm{O}_{3} \text {, ALD } \\
\text { Ir, ALD SnS, Si-H, sapphire, ITO-coated } \\
\text { glass, ALD ZnS, ALD SnO } \text { Snorosilicate }_{2} \text {, boricis }\end{array}$ & $250-350^{\circ} \mathrm{C}$ & None & $\begin{array}{l}\text { Crystallinity function of the } \\
\text { support }\end{array}$ & - & 113 \\
\hline & & $\mathrm{Mo}\left(\mathrm{NMe}_{2}\right)_{4} / \mathrm{H}_{2} \mathrm{~S}$ & $\begin{array}{c}\mathrm{QCM}, \text { amorphous } \mathrm{Al}_{2} \mathrm{O}_{3}, \\
\text { photoresist } / \mathrm{Si}_{3} \mathrm{~N}_{4}\end{array}$ & $60-120^{\circ} \mathrm{C}$ & $\begin{array}{c}1000^{\circ} \mathrm{C} \text { for } 5 \mathrm{~h} \\
\text { under } \mathrm{S} \text { atm }\end{array}$ & $\begin{array}{c}\text { Polycrystalline preferential } \\
\text { orientation }\end{array}$ & - & 114 \\
\hline & & $\mathrm{Mo}\left(\mathrm{NMe}_{2}\right)_{4} / \mathrm{HS}\left(\mathrm{CH}_{2}\right)_{2} \mathrm{SH}$ & $\mathrm{SiO}_{2} / \mathrm{Si}, \mathrm{SiO}_{2}$ particles & $50^{\circ} \mathrm{C}$ & $\begin{array}{l}450^{\circ} \mathrm{C} \text { for } 30 \text { min } \\
\text { in } \mathrm{H}_{2} \\
\text { Or } 800^{\circ} \mathrm{C} \text { for } 30 \\
\min \text { in } \mathrm{Ar}\end{array}$ & $\begin{array}{l}\text { In } \mathrm{H}_{2} \text { : Nanocrystalline } \\
\text { In Ar: Well-crystallized }\end{array}$ & - & 115 \\
\hline & & \multirow{3}{*}{$\mathrm{Mo}(\mathrm{CO})_{6} / \mathrm{CH}_{3} \mathrm{~S}_{2} \mathrm{CH}_{3}$} & $\mathrm{SiO}_{2} / \mathrm{Si}$ & $100^{\circ} \mathrm{C}$ & $\begin{array}{c}\text { None } \\
900^{\circ} \mathrm{C} \text { for } 30 \mathrm{~min} \\
\text { in } \mathrm{Ar} \\
\end{array}$ & $\begin{array}{l}\text { A deposited: Amorphous } \\
\text { Annealed: Crystalline (002) } \\
\text { orientation }\end{array}$ & - & 110 \\
\hline & & & $\mathrm{Au} / \mathrm{Ti} / \mathrm{Si}$ & $100^{\circ} \mathrm{C}$ & None & Amorphous & HER & 112 \\
\hline & & & $\mathrm{CFP}, \mathrm{Si}$ & - & None & $\begin{array}{l}\text { Mix amorphous } \\
\text { nanocrystallites }\end{array}$ & HER & 111 \\
\hline & & \multirow{3}{*}{$\mathrm{Mo}(\mathrm{CO})_{6} / \mathrm{H}_{2} \mathrm{~S}$} & $\begin{array}{c}\mathrm{QCM}, \mathrm{SiO}_{2} / \mathrm{Si}, \mathrm{KBr} \text { pellets, glass slide, } \\
\text { stainless steel }\end{array}$ & $155-170^{\circ} \mathrm{C}$ & None & Amorphous & Li ion battery & 105 \\
\hline & & & $\mathrm{SiO}_{2} / \mathrm{Si}$ & $155-175^{\circ} \mathrm{C}^{*}$ & $\begin{array}{l}\text { RTA at } 900^{\circ} \mathrm{C} \text { in } \\
\text { either } \mathrm{H}_{2} \mathrm{~S} \text { or } \mathrm{Ar}\end{array}$ & $\begin{array}{l}\text { As-grown amorphous } \\
\text { Annealed: well-crystallized } \\
\text { with preferential (002) } \\
\text { orientation // substrate }\end{array}$ & - & 106 \\
\hline & & & Co porous foam & $200^{\circ} \mathrm{C}$ & None & nanocrystals & OER & 107 \\
\hline
\end{tabular}




\begin{tabular}{|c|c|c|c|c|c|c|c|c|}
\hline & \multirow{2}{*}{ PEALD } & \multirow{2}{*}{$\mathrm{Mo}(\mathrm{CO})_{6} / \mathrm{H}_{2} \mathrm{~S}$ plasma } & $\mathrm{SiO}_{2} / \mathrm{Si}$, GaN, Sapphire & $\begin{array}{c}175-225^{\circ} \mathrm{C} \\
\left(175-200^{\circ} \mathrm{C}^{*}\right) \\
\end{array}$ & None & polycrystalline $2 \mathrm{H}-\mathrm{MoS}_{2}$ & - & 108 \\
\hline & & & p-Si photocathode & $200^{\circ} \mathrm{C}$ & $500-700{ }^{\circ} \mathrm{C}$ in $\mathrm{H}_{2} \mathrm{~S}$ & polycrystalline & $\begin{array}{l}\text { Photoectrochemical } \\
\text { water reduction HER }\end{array}$ & 109 \\
\hline & \multirow{3}{*}{$\mathrm{ALD} \mathrm{MoO}_{3}$} & \multirow{2}{*}{$\mathrm{Mo}(\mathrm{CO})_{6} /$ ozone } & $\mathrm{SiO}_{2} / \mathrm{Si}$, glassy carbon, CFP & $165^{\circ} \mathrm{C}$ & Sulfurization $\mathrm{S}$ atm & $\begin{array}{c}\text { polycrystalline randomly } \\
\text { oriented }\end{array}$ & HER & 97 \\
\hline & & & $\begin{array}{c}\mathrm{SiO}_{2} / \mathrm{Si} \\
\text { Sapphire } \\
\end{array}$ & $165^{\circ} \mathrm{C}$ & Sulfurization $\mathrm{S}$ atm & $\begin{array}{c}\text { Cluster } \\
\text { Down to } 2 \mathrm{~L} \text { of } \mathrm{h}-\mathrm{MoS}_{2} \\
\end{array}$ & - & 98 \\
\hline & & $\left(\mathrm{N}^{\mathrm{t} B u}\right)_{2}\left(\mathrm{NMe}_{2}\right)_{2} \mathrm{Mo} / \mathrm{O}_{3}$ & $\mathrm{SiO}_{2} / \mathrm{Si}$ & $300^{\circ} \mathrm{C}$ & Sulfurization $\mathrm{H}_{2} \mathrm{~S}$ & $\begin{array}{c}\text { Function of the process } \\
2 \mathrm{H} \text {-phase }\end{array}$ & - & 99 \\
\hline & \multirow{2}{*}{$\begin{array}{l}\text { PEALD } \\
\mathrm{MoO}_{3}\end{array}$} & $\mathrm{Mo}(\mathrm{CO})_{6} / \mathrm{O}_{2}$ plasma & $\mathrm{SiO}_{2} / \mathrm{Si}$ & $200^{\circ} \mathrm{C}$ & 2 step sulfurization & Polycrystalline & - & 131 \\
\hline & & $\left(\mathrm{N}^{\mathrm{t} B u}\right)_{2}\left(\mathrm{NMe}_{2}\right)_{2} \mathrm{Mo} / \mathrm{O}_{2}$ plama & $\mathrm{SiO}_{2} / \mathrm{Si}$ & $150^{\circ} \mathrm{C}$ & Sulfurization $\mathrm{H}_{2} \mathrm{~S}$ & $\begin{array}{c}\text { Function of the process } \\
2 \mathrm{H} \text {-phase }\end{array}$ & - & 99 \\
\hline & \multirow{4}{*}{ ALET } & \multirow{3}{*}{$\mathrm{Cl}$ radical ads/ $\mathrm{Ar}_{+}$desorp } & CVD $\mathrm{MoS}_{2}$ on $\mathrm{SiO}_{2} / \mathrm{Si}$ & - & None & $2 \mathrm{H}-\mathrm{MoS}_{2}$, well crystallized & - & 94 \\
\hline & & & exfoliated $\mathrm{MoS}_{2}$ & - & None & $2 \mathrm{H}-\mathrm{MoS}_{2}$, well crystallized & FET & 116 \\
\hline & & & CVD MoS on sapphire, $\mathrm{SiO}_{2}$ & $20^{\circ} \mathrm{C}$ & None & $2 \mathrm{H}-\mathrm{MoS}_{2}$, well crystallized & - & 117 \\
\hline & & $\mathrm{O}_{2}$ plasma $/ \Delta 500^{\circ} \mathrm{C}$ & exfoliated $\mathrm{MoS}_{2}$ & $200^{\circ} \mathrm{C}$ & None & $2 \mathrm{H}-\mathrm{MoS}_{2}$, well crystallized & - & ${ }^{118}$ \\
\hline $\mathrm{Nb}: \mathrm{MoSe}_{2}$ & $\begin{array}{l}\text { PEALD } \\
\mathrm{Nb}_{2} \mathrm{O}_{5} \\
\end{array}$ & - & Evaporated $\mathrm{MoO}_{3}$ & - & Selenization & Polycrystalline & Gas sensing & 119 \\
\hline $\mathrm{Mo}_{1-\mathrm{x}} \mathrm{W}_{\mathrm{x}} \mathrm{S}_{2}$ & $\begin{array}{c}\text { PEALD } \\
\mathrm{Mo}_{1-\mathrm{x}} \mathrm{W}_{\mathrm{x}} \mathrm{O}_{\mathrm{y}}\end{array}$ & $\begin{array}{c}\mathrm{Mo}(\mathrm{CO})_{6} / \mathrm{O}_{2} \text { plasma } \\
\mathrm{WH}_{2}\left({ }^{\prime} \mathrm{PrCp}\right)_{2} / \mathrm{O}_{2} \text { plasma }\end{array}$ & $\mathrm{SiO}_{2} / \mathrm{Si}$ & $\begin{array}{l}200{ }^{\circ} \mathrm{C} \\
300^{\circ} \mathrm{C}\end{array}$ & 2 step sulfurization & $\begin{array}{c}\text { Alloy with honeycomb lattice } \\
\text { - vertically composition } \\
\text { control }\end{array}$ & photodetector & 131 \\
\hline \multirow{7}{*}{$\mathrm{WS}_{2}$} & PEALD & $\mathrm{WF}_{6} / \mathrm{H}_{2}$ plasma $/ \mathrm{H}_{2} \mathrm{~S}$ & $\begin{array}{l}\text { Amorphous and polycrystalline } \\
\qquad \mathrm{Al}_{2} \mathrm{O}_{3} / \mathrm{Si}(100)\end{array}$ & $300-450^{\circ} \mathrm{C}$ & None & $\begin{array}{c}\text { Nanocrystalline } \\
\mathrm{T}=300^{\circ} \mathrm{C} \text { : preferential (0002) } \\
\text { orientation } \\
\mathrm{T}=450^{\circ} \mathrm{C} \text { : random orientation }\end{array}$ & - & 123,124 \\
\hline & \multirow{5}{*}{ ALD } & $\begin{array}{c}\mathrm{WF}_{6} / \mathrm{H}_{2} \mathrm{~S} \\
+ \text { Zn catalyst ( } \mathrm{DEZ} \text { or ZnS layer) }\end{array}$ & $\mathrm{SiO}_{2} / \mathrm{Si}, \mathrm{Au}, \mathrm{MEMS}$ & $250-350^{\circ} \mathrm{C}$ & $\begin{array}{l}\text { None } \\
5000^{\circ} \mathrm{C} \text { for } 1 \mathrm{~h} \text { in } \\
\text { vacuum }\end{array}$ & $\begin{array}{c}\mathrm{h}-(002) \text { texture } \\
\text { no change when annealed }\end{array}$ & Solid lubricant & $120-122$ \\
\hline & & $\begin{aligned} & \mathrm{WF}_{6} / \mathrm{H}_{2} \mathrm{~S} \\
&+ \text { Si layer catalyst } \\
&\end{aligned}$ & $\mathrm{Al}_{2} \mathrm{O}_{3} / \mathrm{Si}(100)$ & $300-450^{\circ} \mathrm{C}$ & None & $\begin{array}{c}\text { Nanocrystalline, orientation } \\
\text { depending on T } \\
\end{array}$ & - & 123 \\
\hline & & $\mathrm{WCl}_{5} / \mathrm{H}_{2} \mathrm{~S}$ & $\mathrm{SiO}_{2} / \mathrm{Si}(100)$ & $390^{\circ} \mathrm{C}$ & None & 2H-phase & $\begin{array}{l}\text { back-gated transistor } \\
\text { 2D-heterostructure }\end{array}$ & 125 \\
\hline & & \multirow{2}{*}{$\mathrm{W}(\mathrm{CO})_{6} / \mathrm{H}_{2} \mathrm{~S}$} & $\mathrm{SiO}_{2} / \mathrm{Si}(100), \mathrm{ZnS} / \mathrm{SiO}_{2} / \mathrm{Si}(100)$ & $400{ }^{\circ} \mathrm{C}$ & None & $\begin{array}{l}\text { Hexagonal (002) (101) } \\
\text { orientation }\end{array}$ & Solid lubricant & 126 \\
\hline & & & $\begin{array}{c}\text { Si(111), microscope glass, stainless } \\
\text { steel, CNTs }\end{array}$ & $175-205^{\circ} \mathrm{C}^{*}$ & None & Amorphous & Li-ion battery & 127 \\
\hline & $\begin{array}{l}\text { PEALD } \\
\text { WO3 }\end{array}$ & $\mathrm{WH}_{2}\left({ }^{\prime} \operatorname{PrCp}\right)_{2} / \mathrm{O}_{2}$ plasma & $\mathrm{SiO}_{2} / \mathrm{Si}$ (wafer+nanowires) & $300^{\circ} \mathrm{C}$ & $\begin{array}{c}\text { Sulfurization } \\
\mathrm{Ar} / \mathrm{H}_{2} \mathrm{~S}\end{array}$ & hexagonal & $\begin{array}{c}\text { FET } \\
\text { Gas sensor }\end{array}$ & 128,129 \\
\hline $\mathrm{Al}: \mathrm{WS}_{2}$ & $\begin{array}{l}\mathrm{PEALD} \\
\mathrm{Al}: \mathrm{WO}_{3}\end{array}$ & $\begin{array}{l}\mathrm{W}\left(\mathrm{NMe}_{2}\right)_{4}\left(\mathrm{~N}^{\mathrm{t}} \mathrm{Bu}\right)_{2} / \mathrm{O}_{2} \\
\text { plasma/TMA }\end{array}$ & quartz & $150^{\circ} \mathrm{C}$ & Sulfurization $\mathrm{CS}_{4}$ & $\begin{array}{l}2 \mathrm{H}-\mathrm{WS}_{2}(002) \text { orientation } \\
\text { Doping reduces crystallinity }\end{array}$ & - & 130 \\
\hline \multirow[b]{2}{*}{$\mathrm{WSe}_{2}$} & ALD & $\mathrm{WCl}_{5} / \mathrm{H}_{2} \mathrm{~S}$ & $\mathrm{SiO}_{2} / \mathrm{Si}$ & $390^{\circ} \mathrm{C}$ & None & Well-crystallized, hexagonal & FET & ${ }^{132}$ \\
\hline & SLS & $\mathrm{WCl} /$ /DESe & $\mathrm{SiO}_{2} / \mathrm{Si}$ & $\begin{array}{l}600^{\circ} \mathrm{C}(5 \mathrm{~L}), \\
700^{\circ} \mathrm{C}(3 \mathrm{~L}), \\
800^{\circ} \mathrm{C}(1 \mathrm{~L})\end{array}$ & None & Well-crystallized, hexagonal & FET & 96 \\
\hline
\end{tabular}




\begin{tabular}{|c|c|c|c|c|c|c|c|c|}
\hline \multirow{2}{*}{$\mathrm{Bi}_{2} \mathrm{~S}_{3}$} & $\mathrm{ALD} \mathrm{Bi} \mathrm{O}_{3}$ & $\mathrm{Bi}$ (thd $)_{3} / \mathrm{H}_{2} \mathrm{O}$ & Si(100), quartz & $300^{\circ} \mathrm{C}$ & $\begin{array}{l}\text { Sulfurization } \mathrm{S} \text { atm } \\
500-700^{\circ} \mathrm{C}, 20 \mathrm{~min}\end{array}$ & Orthorhombic & - & 160 \\
\hline & ALD & $\mathrm{Bi}(\text { thd })_{3} / \mathrm{H}_{2} \mathrm{~S}$ & $\mathrm{QCM}$, Si with native oxide, $\mathrm{Al}_{2} \mathrm{O}_{3}$ & $\begin{array}{c}125-300^{\circ} \mathrm{C} \\
\left(175-250^{\circ} \mathrm{C}^{*}\right)\end{array}$ & None & Polycrystalline orthorhombic & - & 154 \\
\hline $\mathrm{Bi}_{2} \mathrm{Se}_{3}$ & ALD & $\mathrm{BiCl}_{3} /\left(\mathrm{Et}_{3} \mathrm{Si}\right)_{2} \mathrm{Se}$ & Si with native oxide, soda lime glass & $\begin{array}{c}165^{\circ} \mathrm{C} \\
160-250^{\circ} \mathrm{C}\end{array}$ & None & $\begin{array}{c}\text { Crystalline rhombohedral } \\
\text { with small amount of } \\
\text { orthorhombic }\end{array}$ & thermoelectric & $148,149,153$ \\
\hline \multirow{5}{*}{$\mathrm{Bi}_{2} \mathrm{Te}_{3}$} & \multirow{5}{*}{ ALD } & $\mathrm{BiCl}_{3} /\left(\mathrm{Et}_{3} \mathrm{Si}\right)_{2} \mathrm{Te}$ & Si with native oxide, soda lime glass & $\begin{array}{c}165^{\circ} \mathrm{C} \\
160-250^{\circ} \mathrm{C}\end{array}$ & None & $\begin{array}{l}\text { Crystalline rhombohedral } \\
\text { with (001) preferred } \\
\text { orientation }\end{array}$ & thermoelectric & $148,149,151$ \\
\hline & & $\mathrm{Bi}\left(\mathrm{NMe}_{2}\right)_{3} /\left(\mathrm{Et}_{3} \mathrm{Si}\right)_{2} \mathrm{Te}$ & Si(100) & $70,120^{\circ} \mathrm{C}$ & None & Polycrystalline rhombohedral & - & \multirow{3}{*}{152} \\
\hline & & $\mathrm{Bi}(\mathrm{NMeEt})_{3} /\left(\mathrm{Et}_{3} \mathrm{Si}\right)_{2} \mathrm{Te}$ & $\mathrm{Si}(100), \mathrm{Al}_{2} \mathrm{O}_{3}(0001), \mathrm{Sb}_{2} \mathrm{Te}_{3}$ & $120^{\circ} \mathrm{C}$ & None & Polycrystalline rhombohedral & - & \\
\hline & & $\begin{array}{c}{\left[\left(\mathrm{Me}_{3} \mathrm{Si}\right)_{2} \mathrm{NBi}-\mu-\mathrm{NSiMe}_{3}\right]_{2}} \\
/ /\left(\mathrm{Me}_{3} \mathrm{Si}\right)_{2} \mathrm{Te}\end{array}$ & $\mathrm{Si}(100), \mathrm{SiO}_{2} \mathrm{i}$ & $120,170^{\circ} \mathrm{C}$ & None & Polycrystalline rhombohedral & - & \\
\hline & & $\mathrm{BiCl}_{3} /\left(\mathrm{Me}_{3} \mathrm{Si}\right)_{2} \mathrm{Te}$ & Si wafer, $300 \mathrm{~nm} \mathrm{SiO}{ }_{2} / \mathrm{Si}$ & $100-170{ }^{\circ} \mathrm{C}$ & None & Polycrystalline rhombohedral & thermoelectric & $150,158,159$ \\
\hline $\mathrm{FeS}_{\mathrm{x}}$ & ALD & $\mathrm{Fe}(\mathrm{amd})_{2} / \mathrm{H}_{2} \mathrm{~S}$ & $\begin{array}{l}\text { Trenches }(10: 1), \mathrm{y}^{-} \mathrm{Al}_{2} \mathrm{O}_{3} \text { powder, } \\
\text { UV/ozone-treated planar } \mathrm{Si}\end{array}$ & $80-200^{\circ} \mathrm{C}$ & None & $\begin{array}{c}\text { Well-crystallized } \\
\mathrm{T} \leq 120^{\circ} \mathrm{C} \text { : tetragonal } \\
\mathrm{T} \geq 160^{\circ} \mathrm{C} \text { : hexagonal or } \\
\text { monoclinic } \\
\end{array}$ & Hydrogenation catalysis & 92 \\
\hline GaS & ALD & $\mathrm{Ga}_{2}\left(\mathrm{NMe}_{2}\right)_{6} / \mathrm{H}_{2} \mathrm{~S}$ & $\begin{array}{c}\text { Si wafer, fused silica, Si trenches, } \\
\text { capillary glass arrays, copper foils, QCM, } \\
\text { SWCNTs }\end{array}$ & $125-225^{\circ} \mathrm{C}$ & None & amorphous & Li-ion battery & 90,147 \\
\hline GeS & ALD & $\begin{array}{c}\mathrm{N}^{2}, \mathrm{~N}^{3} \text {-di-tert-butylbutane-2,3- } \\
\text { diamine Ge (II)/H} / \mathrm{H}_{2} \mathrm{~S}\end{array}$ & $\mathrm{SiO}_{2}$, hole with aspect ratio of $\sim 40: 1$ & $50-75^{\circ} \mathrm{C}^{*}$ & None & Amorphous & - & 88 \\
\hline InSe & ALD & $\operatorname{lnCl} / \mathrm{H}_{2} \mathrm{Se}(8 \%$ in $\mathrm{Ar})$ & $\begin{array}{c}320 \mathrm{~nm} \mathrm{SiO}_{2} / \mathrm{Si} \text {, glass slide, } \mathrm{FTO} \text { coated } \\
\text { glass }\end{array}$ & $310-380^{\circ} \mathrm{C}$ & None & Hexagonal $(\gamma-\ln S e)$ & pn diode & 93 \\
\hline $\ln _{2} \mathrm{Se}_{3}$ & ALD & $\operatorname{lnCl}_{3} /\left(\mathrm{Et}_{3} \mathrm{Si}\right)_{2} \mathrm{Se}$ & Si with native oxide & $295^{\circ} \mathrm{C}$ & None & Crystalline & - & 148,149 \\
\hline$\gamma-\mathrm{MnS}$ & ALD & $\mathrm{Mn}(\mathrm{EtCp})_{2} / \mathrm{H}_{2} \mathrm{~S}$ & Si wafer, fused quartz, QCM, AAO & $100-225^{\circ} \mathrm{C}$ & None & $\begin{array}{c}\mathrm{T}<150^{\circ} \mathrm{C}: \text { wurtzite }(\gamma-\mathrm{MnS}) \\
\mathrm{T}>150^{\circ} \mathrm{C}: \text { mix cubic }(\alpha-\mathrm{MnS}) / \\
\gamma-\mathrm{MnSS}\end{array}$ & Li-ion battery & 89 \\
\hline NiS & ALD & $\mathrm{Ni}(\text { thd })_{2} / \mathrm{H}_{2} \mathrm{~S}$ & $\begin{array}{c}\mathrm{Al}_{2} \mathrm{O}_{3}-/ \mathrm{Gold}-\text {-coated } \mathrm{QCM}, \mathrm{Si}(111) \text { with } \\
\text { native oxide, } \mathrm{KBr} \text { pellet,soda lime glass, } \\
\text { FTO coated glass }\end{array}$ & $\begin{array}{c}175-350^{\circ} \mathrm{C} \\
\left(175-250^{\circ} \mathrm{C}^{*}\right)\end{array}$ & None & Polycrystalline $\beta$-NiS & Dye sensitized solar cell & 91 \\
\hline $\mathrm{Sb}_{2} \mathrm{Se}_{3}$ & ALD & $\mathrm{SbCl}_{3} / \mathrm{H}_{2} \mathrm{Se}$ & $\begin{array}{c}320 \mathrm{~nm} \mathrm{SiO}_{2} / \mathrm{Si} \text {, glass slide, FTO coated } \\
\text { glass }\end{array}$ & $270-320^{\circ} \mathrm{C}$ & None & Orthorhombic & pn diode & 93 \\
\hline \multirow[b]{3}{*}{$\mathrm{Sb}_{2} \mathrm{Te}_{3}$} & \multirow[b]{3}{*}{ ALD } & $\mathrm{SbCl}_{3} /\left(\mathrm{Et}_{3} \mathrm{Si}\right)_{2} \mathrm{Te}$ & Si with native oxide, glass & $60-140^{\circ} \mathrm{C}$ & None & Crystalline rhombohedral & - & 148,149 \\
\hline & & $\mathrm{Sb}(\mathrm{OEt})_{3} /\left(\mathrm{Et}_{3} \mathrm{Si}\right)_{2} \mathrm{Te}$ & Si with native oxide & $140^{\circ} \mathrm{C}$ & None & - & - & 149 \\
\hline & & $\mathrm{SbCl}_{3} /\left(\mathrm{Me}_{3} \mathrm{Si}\right)_{2} \mathrm{Te}$ & $\begin{array}{l}\mathrm{Si}(100) \text {, Si with native oxide, } 300 \mathrm{~nm} \\
\mathrm{SiO}_{2} / \mathrm{Si}, \mathrm{Pt}, \mathrm{CVD} \text { graphene }\end{array}$ & $\begin{array}{c}50-180^{\circ} \mathrm{C} \\
\text { Optimal : } 70^{\circ} \mathrm{C}\end{array}$ & None & $\begin{array}{l}\text { Rhombohedral } \\
\text { Lattice plane parallel to } \\
\text { graphene }\end{array}$ & thermoelectric & $156,158,159$ \\
\hline Sns & ALD & $\mathrm{Sn}(\mathrm{acac})_{2} / \mathrm{H}_{2} \mathrm{~S}$ & $\begin{array}{l}\text { Gold or } \mathrm{Al}_{2} \mathrm{O}_{3} \text { coated QCM } \\
\text { ALD } \mathrm{WS}_{2} \text { on Si wafer }\end{array}$ & $\begin{array}{c}80-225^{\circ} \mathrm{C} \\
\left(80-160^{\circ} \mathrm{C}^{*}\right) \\
3900^{\circ} \mathrm{C}\end{array}$ & None & $\begin{array}{c}\text { Long pulse: cubic } \\
\text { Short pulse: orthorhombic } \\
\mathrm{T} \geq 300^{\circ} \mathrm{C} \text { : singe phase } \\
\text { Orthorhombic misaligned on } \\
\mathrm{WS}_{2} \\
\end{array}$ & - & $\begin{array}{r}133,134 \\
125\end{array}$ \\
\hline
\end{tabular}




\begin{tabular}{|c|c|c|c|c|c|c|c|c|}
\hline & & $\mathrm{Sn}(\mathrm{amd})_{2} / \mathrm{H}_{2} \mathrm{~S}$ & $\begin{array}{c}\text { Thermal } \mathrm{SiO}_{2}, 450 \mathrm{~nm} \text { Mo coated soda } \\
\text { lime glass }\end{array}$ & $\begin{array}{c}100-250^{\circ} \mathrm{C} \\
\left(100-200^{\circ} \mathrm{C}^{*}\right)\end{array}$ & $\begin{array}{c}\text { None } \\
400^{\circ} \mathrm{C} \text { for } 1 \mathrm{~h} \text { in } \mathrm{N}_{2} \\
\text { or } \mathrm{H}_{2} \mathrm{~S}\end{array}$ & $\begin{array}{c}\text { Polycrystalline, columnar } \\
\text { orthorhombic } \\
\mathrm{N}_{2} \text {-annealed: more columnar } \\
\mathrm{H}_{2} \mathrm{~S} \text {-annealed: larger grains }\end{array}$ & Solar cell & $88,136-139$ \\
\hline & & $\begin{array}{l}\mathrm{N}^{2}, \mathrm{~N}^{3} \text {-di-tert-butylbutane-2,3- } \\
\text { diamine tin }(\mathrm{II}) / \mathrm{H}_{2} \mathrm{~S}\end{array}$ & $\mathrm{SiO}_{2}$ & $50-125^{\circ} \mathrm{C}^{*}$ & None & Polycrystalline Orthorhombic & - & 88 \\
\hline & & TDMASn $/ \mathrm{H}_{2} \mathrm{~S}$ & $\mathrm{H}$-Si wafer, $100 \mathrm{~nm} \mathrm{SiO}_{2} / \mathrm{Si}$, glass & $\begin{array}{c}60-200^{\circ} \mathrm{C} \\
\text { (for SnS T>160 } \\
{ }^{\circ} \mathrm{C} \text { ) }\end{array}$ & $\begin{array}{c}\text { None } \\
\text { RTA } 300-360^{\circ} \mathrm{C}, 30 \\
\min \text { in } \mathrm{H}_{2}\end{array}$ & $\begin{array}{c}\mathrm{T}>160^{\circ} \mathrm{C} \text { : Orthorhombic }+ \\
\text { mixture with hexagonal } \mathrm{SnS}_{2} \\
\text { Annealed above } 300^{\circ} \mathrm{C} \\
\text { orthorhombic }\end{array}$ & - & 140,142 \\
\hline Sb:SnS & ALD & $\mathrm{Sn}(\mathrm{amd})_{2} / \mathrm{H}_{2} \mathrm{~S} / \mathrm{Sb}\left(\mathrm{N}\left(\mathrm{CH}_{3}\right)_{2}\right)_{3}$ & Amorphous $\mathrm{SiO}_{2}$ & $200^{\circ} \mathrm{C}$ & None & Orthorhombic & Solar cell & 135 \\
\hline \multirow{3}{*}{$\mathrm{SnS}_{2}$} & \multirow{3}{*}{ ALD } & \multirow[t]{2}{*}{ TDMASn $/ \mathrm{H}_{2} \mathrm{~S}$} & $\begin{array}{c}\text { H-Si wafer, } 100 \mathrm{~nm} \mathrm{SiO}_{2} / \mathrm{Si} \text {, glass, ALD } \\
\mathrm{ZrO}_{2} \text { on } \mathrm{SiO}_{2} / \mathrm{Si}\end{array}$ & $\begin{array}{c}60-200{ }^{\circ} \mathrm{C} \\
\left(\text { for } \mathrm{SnS}_{2}:\right. \\
140-150{ }^{\circ} \mathrm{C} \text { ) }\end{array}$ & $\begin{array}{c}\text { None } \\
250-350^{\circ} \mathrm{C}, 20 \mathrm{~min} \\
\text { under } 5 \% \mathrm{H}_{2} \mathrm{~S} \text { in } \mathrm{Ar}\end{array}$ & $\begin{array}{c}\mathrm{T}=140-150^{\circ} \mathrm{C}: \text { Hexagonal } \\
\mathrm{T}<140^{\circ} \mathrm{C} \text { amorphous } \\
\text { Annealed: hexagonal }\end{array}$ & FET & $\begin{array}{r}140 \\
141,143\end{array}$ \\
\hline & & & $100 \mathrm{~nm} \mathrm{SiO} / 2 / \mathrm{Si}$, glass & $100-160^{\circ} \mathrm{C}$ & $\begin{array}{l}\text { RTA } 250^{\circ} \mathrm{C}, 30 \mathrm{~min} \\
\text { in } \mathrm{H}_{2} \\
\end{array}$ & Annealed: hexagonal & - & 142 \\
\hline & & $\mathrm{Sn}(\mathrm{OAc})_{4} / \mathrm{H}_{2} \mathrm{~S}$ & Si wafer, $\mathrm{SiO}_{2}$, soda-lime glass & $150^{\circ} \mathrm{C}$ & $\begin{array}{c}250^{\circ} \mathrm{C}, 1 \mathrm{~h} \text { in } \\
\mathrm{H}_{2} \mathrm{~S} / \mathrm{N}_{2}\end{array}$ & Hexagonal & - & 144 \\
\hline \multirow[t]{2}{*}{$\mathrm{TiS}_{x}$} & \multirow[t]{2}{*}{ ALD } & \multirow[t]{2}{*}{$\mathrm{TiCl}_{4} / \mathrm{H}_{2} \mathrm{~S}$} & $\begin{array}{c}\text { Soda-lime glass, } \mathrm{Si}, \mathrm{TiN}, \mathrm{ZnS}, \mathrm{Rh}, \mathrm{Ir}, \mathrm{Pd} \\
\mathrm{Pt}, \mathrm{Ru}, \mathrm{ZnS} \text { on AAO }\end{array}$ & $400-500^{\circ} \mathrm{C}$ & None & $\begin{array}{c}\text { Hexagonal on soda-lime } \\
\text { glass, TiN, Pd,... } \\
\text { (0001)-orientated hexagonal } \\
\text { on } \mathrm{ZnS}, \mathrm{Pt} \\
\text { Amorphous on } \mathrm{Rh}\end{array}$ & - & 146 \\
\hline & & & $\begin{array}{c}\mathrm{Al}_{2} \mathrm{O}_{3} \text { coated } \mathrm{QCM}, \text { glass, } \mathrm{Si}(111), \mathrm{ZnS} \\
\text { coated } \mathrm{Si} \text {, porous } \mathrm{TiO}_{2} \text { films }\end{array}$ & $\begin{array}{c}75-250^{\circ} \mathrm{C}(125- \\
\left.200{ }^{\circ} \mathrm{C}^{*}\right)\end{array}$ & None & Crystalline $\mathrm{TiS}_{2}$ & Solar cell & 145 \\
\hline \multicolumn{9}{|c|}{ ALD heterostructures } \\
\hline $\begin{array}{l}\mathrm{Bi}_{2} \mathrm{Te}_{3} / \\
\mathrm{Sb}_{2} \mathrm{Te}_{3}\end{array}$ & ALD & $\begin{array}{l}\mathrm{BiCl}_{3} /\left(\mathrm{Me}_{3} \mathrm{Si}\right)_{2} \mathrm{Te} \\
\mathrm{SbCl}_{3} /\left(\mathrm{Me}_{3} \mathrm{Si}\right)_{2} \mathrm{Te}\end{array}$ & Si wafer & $\begin{array}{l}165-170{ }^{\circ} \mathrm{C} \\
70^{\circ} \mathrm{C}\end{array}$ & $\begin{array}{l}\text { Long } \mathrm{SbCl}_{3} \text { pulse to } \\
\text { initiate growth }\end{array}$ & $\begin{array}{c}\text { Polycrystalline, } \\
\text { rhombohedral - local epitaxy }\end{array}$ & thermoelectric & 157-159 \\
\hline $\begin{array}{l}\text { InSe/ } \\
\mathrm{Sb}_{2} \mathrm{Se}_{3}\end{array}$ & ALD & $\begin{array}{l}\mathrm{InCl} / \mathrm{H}_{2} \mathrm{Se} \\
\mathrm{SbCl}_{3} / \mathrm{H}_{2} \mathrm{Se}\end{array}$ & $320 \mathrm{~nm} \mathrm{SiO} / 2 / \mathrm{Si}$, FTO coated glass & $310^{\circ} \mathrm{C}$ & None & No intermixing & pn diode & 93 \\
\hline $\begin{array}{l}\mathrm{WS}_{2} / \\
\mathrm{SnS}\end{array}$ & ALD & $\begin{array}{c}\mathrm{WCl} / \mathrm{I}_{5} / \mathrm{H}_{2} \mathrm{~S} \\
\mathrm{Sn}(\mathrm{acac})_{2} / \mathrm{H}_{2} \mathrm{~S}\end{array}$ & $55-940 \mathrm{~nm} \mathrm{SiO}_{2} / \mathrm{Si}$ & $300{ }^{\circ} \mathrm{C}$ & None & $\begin{array}{c}\text { Hexagonal } \\
\text { Orthorhombic } \\
\text { misaligned }\end{array}$ & FET & 125 \\
\hline
\end{tabular}




\section{2D Metal oxides}

Metal oxides $\left(\mathrm{MO}_{\mathrm{x}}\right.$ ) offer potential for wide range of applications especially in semiconductor ${ }^{27}$ and environmental areas. ${ }^{161}$ With the recent development of 2D materials, monolayers of metal oxides are legitimate in this competitive field and $\mathrm{MO}_{\mathrm{x}}$ sheets have already been exfoliated from bulk. ${ }^{2}$ Therefore, ALD metal oxides find new applications in 2D material area beyond the semiconductor industry, especially because of their low cost and excellent catalytic properties. Current challenges and future prospects of $\mathrm{MO}_{\mathrm{x}}$ monolayers deal with water splitting, ${ }^{162,163}$ photocatalytic materials, ${ }^{164}$ waste water treatment, ${ }^{165}$ pollution removal, ${ }^{166}$ and "smart windows". ${ }^{164}$ The most studied 2D $\mathrm{MO}_{x}$ monolayers deposited by ALD (Table 3) will be briefly reviewed to highlight the potential of the technique in the field of $2 \mathrm{D}$ materials. Particular attention is given to ALD processes of $\mathrm{MoO}_{3}$ and $\mathrm{WO}_{3}$ as they are the most known $2 \mathrm{D}$ oxides and they can be sulfurized into TMDs as described in section 2. Regarding the other $\mathrm{MO}_{\mathrm{x}}$, one focuses only on works reporting mono to few layers.

\subsection{Fabrication of $\mathrm{MoO}_{3}$}

Molybdenum trioxide $\mathrm{MoO}_{3}$ exhibits unique electrical, catalytic, and optical properties and might act as an excellent material for a number of applications, like solar cells, ${ }^{167-170}$ organic photovoltaics, ${ }^{171}$ organic light emitting diode, ${ }^{172}$ lithium battery cathodes, ${ }^{173}$ catalytic, ${ }^{174,175}$ electrochromic ${ }^{176,177}$ as well as antimicrobial material. ${ }^{178}$ Various metal precursors, combined with an oxygen source, usually $\mathrm{O}_{2}, \mathrm{O}_{3}$ or $\mathrm{H}_{2} \mathrm{O}$, are used to grow $\mathrm{MoO}_{3}$ thin films by either thermal or plasma enhanced ALD.

Many groups use bis(tert-butylimido) bis(dimethylamido) molybdenum ((tBuN) $\left.\left(\mathrm{NMe}_{2}\right)_{2} \mathrm{Mo}\right)$ as precursor because it provides good volatility and thermal stability. ${ }^{99,167-170,179,180}$ Using thermal process and ozone, ALD window ranging from 50 to $300^{\circ} \mathrm{C}$ (Figure 16a) is demonstrated. $\mathrm{MoO}_{3}$ deposited film shows low contamination levels $\left(\leq 0.5 \%\right.$ of $\mathrm{C}$ and $\mathrm{H}$ ) at $300{ }^{\circ} \mathrm{C}^{180}$ PEALD based on $\mathrm{O}_{2}$ plasma ${ }^{167-170,179}$ permits high growth rates at substrate temperatures between $50^{\circ} \mathrm{C}$ and $350^{\circ} \mathrm{C}$. Below $250^{\circ} \mathrm{C}$, amorphous films are deposited while a transition to polycrystalline ones is observed at higher temperatures. ${ }^{168,169,179}$ The as-deposited films are slightly sub-stoichiometric with respect to $\mathrm{MoO}_{3}$ due to oxygen vacancies, ${ }^{169,179}$ however the stoichiometry can be adjusted by the plasma parameters. ${ }^{170}$ The high purity of the films is demonstrated with no detectable $\mathrm{C}$ and $\mathrm{N}$ contamination despite a hydrogen content between 3 and 11 at.\%. ${ }^{168,169,179}$ The films present a high transparency in the visible region. ${ }^{167-170}$

Synthesis of $\mathrm{MoO}_{3}$ is also widely achieved using $\mathrm{Mo}(\mathrm{CO})_{6}$ reacted with either ozone or water. ${ }^{98,181-183}$ The growth dynamics is explored by in-situ QCM, which shows an ALD window between 152 and 172 ${ }^{\circ} \mathrm{C} .{ }^{181,182}$ Growth using a single oxygen precursor is hardly detectable while combination of various 
oxygen sources leads to a GPC as high as $0.75 \AA$ A/cycle, to a linear growth and negligible nucleation delay. The as-deposited films are uniform with low surface roughness, oxygen deficient at the substrate interface and amorphous. Post-annealing in air at elevated temperature $\left(500-600^{\circ} \mathrm{C}\right)$ permits progressive transition from amorphous to monoclinic ${ }^{181}$ or orthorhombic ${ }^{182}$ phase. ${ }^{183}$ Nevertheless, crystallization process involves significant mass transport thereby creating uncoated areas and roughness (Figure 16b). Combining $\mathrm{Mo}(\mathrm{CO})_{6}$ with $\mathrm{Co}(\text { thd })_{2}$ and $\mathrm{CoCp}_{2}$, Diskus et al. ${ }^{184}$ succeed in growing cobalt molybdenum oxides. Use of water as oxygen source induces a surface controlled mechanism towards the particular $\mathrm{CoMoO}_{4}$ composition. The as-obtained films are amorphous and can be post-converted into either $\beta-\mathrm{CoMoO}_{4}$ or $\mathrm{Co}$ doped $\alpha-\mathrm{MoO}_{3}$.

More complex Mo precursors are also investigated. In particular, $\mathrm{MoO}_{2}\left(\mathrm{R}_{2} A M D\right)_{2}\left(A M D=N, N^{\prime}\right.$-di-Racetamidinate) complexes ( $\mathrm{R}=\mathrm{Cy}$; $\mathrm{i} P$ ), which are air- and moisture-stable, are reacted with $\mathrm{O}_{3}{ }^{185}$ The complex with ${ }^{\mathrm{P} r}$, accessible in high yields and easy to handle without mass loss, leads to nitride-free $\mathrm{MoO}_{3}$ thin films. ${ }^{185}$ From bis(ethylbenzene) molybdenum and $\mathrm{H}_{2} \mathrm{O}$, Drake and Stair ${ }^{186}$ report $\mathrm{MoO}_{x}$ ALD that demonstrates a linear growth rate of $0.08 \AA$ /cycle in the $135-150{ }^{\circ} \mathrm{C}$ window. Compared to the reported GPC of $\mathrm{Mo}(\mathrm{CO})_{6}$ and $(\mathrm{tBuN})_{2} \mathrm{Mo}\left(\mathrm{NMe}_{2}\right)_{2}$, this lower rate allows a more precise control of the molybdenum content. $\mathrm{Si}\left(\mathrm{CH}_{3}\right)_{3} \mathrm{CpMo}(\mathrm{CO})_{2}\left(\eta^{3}-2\right.$-methylallyl) (MOTSMA), a new molybdenum precursor, presents good thermal stability, high volatility, and allows higher deposition rate compared to the previous $\mathrm{Mo}(\mathrm{CO})_{6}$ precursor. ${ }^{187}$ As it is halide free, no corrosive byproducts are released during the deposition. Use of MOTSMA and ozone mitigates eventual long nucleation delay (> 15 cycles) observable at low growth temperature (Figure 16c). MOTSMA is initially grafted at 350 ${ }^{\circ} \mathrm{C}$, through standard ligand exchange with $\mathrm{OH}$-terminated silicon oxide surfaces, resulting in $\mathrm{MoO}_{2}$ formation and thus shortening the incubation period ( $\sim 9$ cycles). The substrate temperature is lowered to $250-300{ }^{\circ} \mathrm{C}$, yielding good quality $\mathrm{MoO}_{3}$ films. ${ }^{187}$

Uniform and highly transparent thin layers of $\mathrm{MoO}_{3}$ are formed on large substrates $(300 \mathrm{~mm} \mathrm{Si}$ wafers) by oxidation in UV ozone of an ALD Mo thin layer ${ }^{171}$ fabricated from $\mathrm{Si}_{2} \mathrm{H}_{6}$ and $\mathrm{MoF}_{6}$ at 200 ${ }^{\circ} \mathrm{C} .{ }^{188}$ They prove to be efficient as anode buffer layers for organic photovoltaic cells. Compared to commonly used buffer layers, $\mathrm{MoO}_{3}$ shows higher short-circuit, due to improved optical transmission. ${ }^{171}$

As introduced in part 2.1, synthesis of the $\mathrm{MOS}_{2}$ TMD is realized by sulfurization of ALD deposited molybdenum oxide film. The conformal growth offered by the ALD technique allows controlling the quality of the final grown $\mathrm{MoS}_{2}$ film by mastering the characteristics of the oxide film (stoichiometry, thickness, substrate coverage, grain size). ${ }^{98,99}$ 

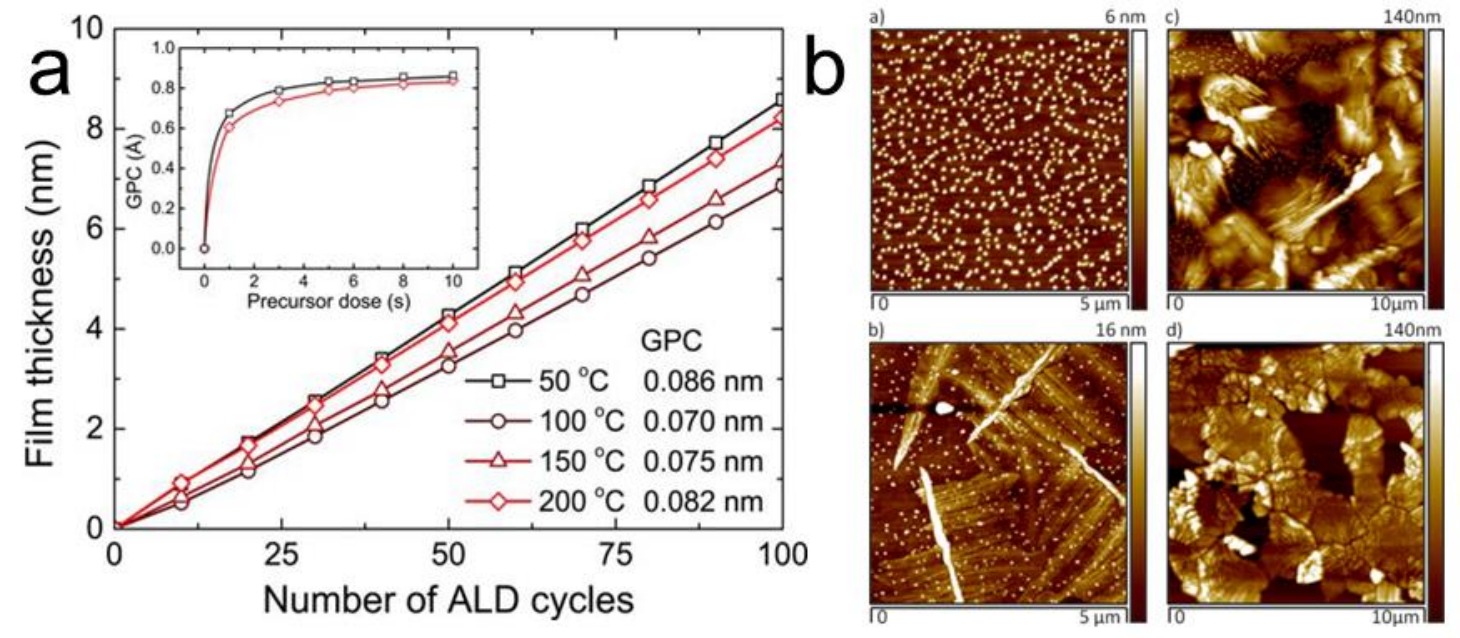

MOTSMA Surface Reaction and Subsequent Reaction with Ozone
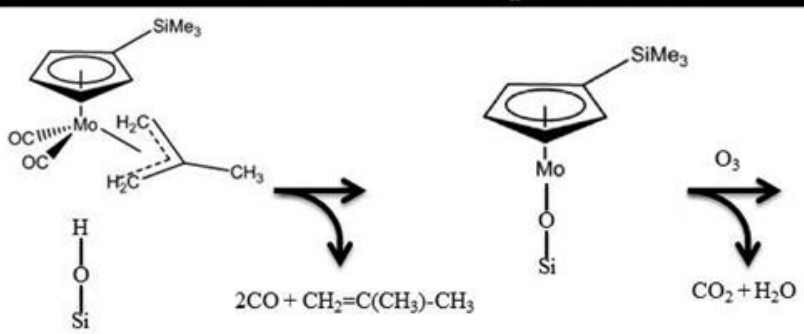

C

\section{Steady State Cycle}

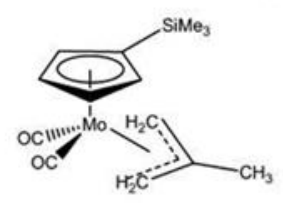

이
Mo
M

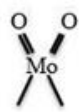

$\uparrow$

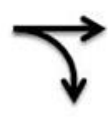

$2 \mathrm{CO}_{2}$
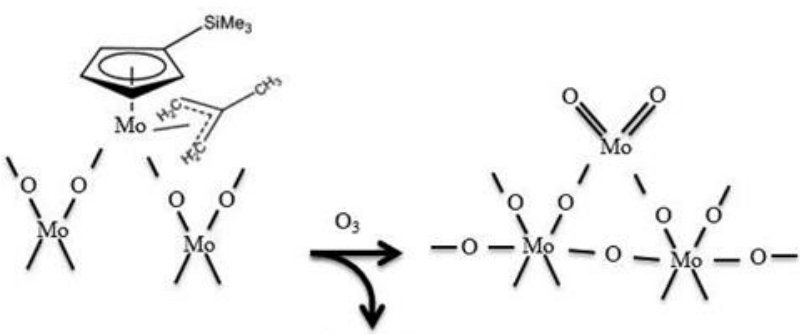

$\mathrm{CO}_{2}+\mathrm{H}_{2} \mathrm{O}$

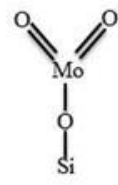

\section{ALD Process}

Figure 16. a) Influence of the number of ALD cycles on the $\mathrm{MoO}_{x}$ film thickness at deposition temperatures ranging from 50 ${ }^{\circ} \mathrm{C}$ to $200{ }^{\circ} \mathrm{C}$ and corresponding GPC. Inset: Precursor dose saturation curves at $50{ }^{\circ} \mathrm{C}$ and $200{ }^{\circ} \mathrm{C}$. Reproduced with permission from ref. ${ }^{169}$, b) AFM topographies of ALD deposited $\mathrm{MoO}_{3}$ thin films (a) as deposited, and annealed in air for (b) $8 \mathrm{~min}$ at $400{ }^{\circ} \mathrm{C}$, (c) $4 \mathrm{~min}$ at $600{ }^{\circ} \mathrm{C}$, and (d) $7.5 \mathrm{~min}$ at $600{ }^{\circ} \mathrm{C}$. Reproduced with permission from ref. ${ }^{183}$, c) Scheme of ALD mechanism between MOTSMA and ozone. Reproduced with permission from ref. ${ }^{187}$.

\subsection{Tungsten oxide}

$\mathrm{WO}_{3}$ appears as one of the most attractive transition metal oxide semiconductors. It has been successfully used in optical, ${ }^{189,190}$ energy ${ }^{191-193}$ and environmental ${ }^{193-195}$ applications. Many of these domains require $\mathrm{WO}_{3}$ as thin films, achievable by $\mathrm{ALD}$ as described hereafter. 
Tungsten hexacarbonyl $\mathrm{W}(\mathrm{CO})_{6}$ is one of the most used precursors. ${ }^{196-200}$ Using ozone as oxygen source, narrow ALD window between 195 and $205^{\circ} \mathrm{C}$ with a GPC of $0.2 \AA$ A $/$ cycle is noted. ${ }^{196,197}$ While Nandi and Sarkar ${ }^{196}$ report amorphous films that could be converted to monoclinic $\mathrm{WO}_{3}$ upon annealing, Malm et al. ${ }^{197}$ obtain partially crystallized as-deposited films that can considerably be improved by annealing at $600-1000^{\circ} \mathrm{C}$ under oxygen or nitrogen atmospheres. On the other hand, from $\mathrm{H}_{2} \mathrm{O}_{2}$ and $\mathrm{W}(\mathrm{CO})_{6}$, thin $\mathrm{WO}_{x}$ films are successfully grown onto $\mathrm{TiO}_{2}$ particles using a fluidized bed reactor. ${ }^{198}$ The $\mathrm{WO}_{\mathrm{x}}$ films result from both ALD-like and CVD-based growth modes, the determined $\mathrm{W} / \mathrm{Ti}$ atomic ratio being partially dependent on the tungsten and oxygen precursor pulse lengths. These films inhibit the $\mathrm{TiO}_{2}$ anatase-to-rutile phase conversion at high temperature annealing, without $\mathrm{WO}_{3}$ crystallization. ${ }^{198}$ Using $\mathrm{H}_{2} \mathrm{O}$ as oxygen source, the surface roughness increases and the initial amorphous layer completely crystallizes into polycrystalline film under post-annealing. ${ }^{199,200}$ In addition to $\mathrm{W}(\mathrm{CO})_{6}, \mathrm{WF}_{6}$ reacted with water is widely studied and a very low deposition rate, ascribed to poor adsorption of $W_{F_{6}}$ on the oxide surface, is observed. ${ }^{201-203}$ The tungsten oxyfluorides in situ generated can be used as precursors together with $\mathrm{H}_{2} \mathrm{O}$ for the deposition of monoclinic $\mathrm{WO}_{3}$ films at $200^{\circ} \mathrm{C}$, with a maximum GPC about $0.8 \AA$ A $/$ cycle. ${ }^{201}$ Strobel et al. ${ }^{202}$ overcome the poor adsorption using PEALD on silicon substrates. The temperature range of $30-180^{\circ} \mathrm{C}$ inhibits etching and allows $\mathrm{WF}_{6}$ adsorption. However, the release of $\mathrm{HF}$ damages most substrates including silicon containing compounds.

Therefore, ALD based on tungsten amide $(\mathrm{tBuN})_{2} \mathrm{~W}\left(\mathrm{NMe}_{2}\right)_{2}$, first used by Becker et al. ${ }^{204}$ for $\mathrm{WN}$ thin films, and water, is developed. ${ }^{163,205-207}$ This $W$ source presents a low vapor pressure suitable for ALD. The linear relationship between the film thickness and the number of cycles is demonstrated ${ }^{163}$ and the deposition of one single layer $\mathrm{WO}_{3}$ with thickness of $0.7 \pm 0.07 \mathrm{~nm}$ across a large area is achieved without affecting the underlying $\mathrm{SiO}_{2} / \mathrm{Si}$ substrate. ${ }^{205}$ This $\mathrm{WO}_{3}$ monolayer, used as a photodetector, exhibits high sensitivity, wide-range photoresponse, extremely fast response time and superior longterm stability. ${ }^{206}$

An alternative precursor with oxo-amidinate functionalities, $\mathrm{WO}_{2}\left(\mathrm{~N}, \mathrm{~N}^{\prime} \text {-di-tertbutylacetamidinate }\right)_{2}$, presenting good volatility and thermal stability, is also introduced. Associated with $\mathrm{H}_{2} \mathrm{O}$, it allows growing $\mathrm{WO}_{3}$ ultrathin films $(<10 \mathrm{~nm})$ on Si (100) wafers at temperatures higher than $200{ }^{\circ} \mathrm{C}$. Linear growth is reached after $\sim 20$ cycles. The as-synthesized $\mathrm{WO}_{3}$ thin films are porous and can be crystallized by a post-annealing treatment. Nevertheless, the annealing causes spontaneous formation of nanowires that are randomly oriented on the surface, decreasing the surface coverage without affecting the roughness. ${ }^{208}$

HWALD based on a tungsten wire, heated at $660^{\circ} \mathrm{C}$ under successive $\mathrm{N}_{2}, \mathrm{O}_{2}$ and $\mathrm{H}_{2}$ atmospheres that acts as the metal precursor allows depositing tungsten oxide. During the growth under $\mathrm{N}_{2}$, the W wire oxidizes with injection of $\mathrm{O}_{2}$ pulses, creating continuous $\mathrm{WO}_{3}$ vapors that deposit on the 
substrate. The stoichiometry of the film can be adjusted by varying the oxygen and hydrogen contents, leading to either stoichiometric $\mathrm{WO}_{3}$, oxygen deficient $\mathrm{WO}_{\mathrm{x}}(\mathrm{x}<3)$, hydrogen doped $\mathrm{WO}_{3}$, or sub-stoichiometric hydrogen doped $\mathrm{WO}_{\mathrm{x}}$. Each of these deposited tungsten oxides exhibits particular optical properties related to intrinsic electronic structure, which can be tuned by the ALD parameters. ${ }^{209}$

In addition to $\mathrm{WO}_{3}, \mathrm{~W}_{2} \mathrm{O}_{3}$ thin films are ALD grown from tungsten(III) amide $\mathrm{W}_{2}\left(\mathrm{NMe}_{2}\right)_{6}$ and water. ${ }^{210}$ The metal oxidation state of $\mathrm{W}$ reactant determines the one of the oxide thin film $\left(\mathrm{W}^{3+}\right)$. Employing mid- or low-valent metal precursors affords oxide or nitride phases having the same oxidation state than the precursor. Growth of $\mathrm{W}_{2} \mathrm{O}_{3}$ thin films is observed at temperatures between 140 and $200{ }^{\circ} \mathrm{C}$ with a GPC of $1.4 \AA$ Acycle. The possibility of growing $\mathrm{W}_{2} \mathrm{O}_{3}$ thin films at such low temperatures is explained by the high reactivity of $\mathrm{W}_{2}\left(\mathrm{NMe}_{2}\right)_{6}$ toward water, as well as the low oxidizing power of water.

Finally, like $\mathrm{MoS}_{2}, \mathrm{WS}_{2}$ nanosheets are produced by sulfurization of the corresponding ALD metal oxide. ${ }^{128,129} \mathrm{WO}_{3}$ films, first deposited from $\mathrm{WH}_{2}\left({ }^{\mathrm{i}} \mathrm{PrCp}\right)_{2}$ and $\mathrm{O}_{2}$ on $\mathrm{SiO}_{2} / \mathrm{Si}$ substrates at $300^{\circ} \mathrm{C}$, are then sulfurized at $1000^{\circ} \mathrm{C}$ for 30 min with a mixed flow of $\mathrm{Ar}$ and $\mathrm{H}_{2} \mathrm{~S}$. The synthesized $\mathrm{WS}_{2}$ layer retains the inherent benefits of the oxide ALD process, which include thickness controllability and uniformity, reproducibility and high conformality. The number of $\mathrm{WS}_{2}$ layers (from mono- to multilayers) is systematically controlled by adjusting the number of cycles of $\mathrm{ALD} \mathrm{WO}_{3}{ }^{129}$

\subsection{Other oxides}

In the literature, few papers discuss the ALD growth from TriMethylAluminum (TMA) of near 2D aluminum oxide layers and suspended nanosheets. Especially, the mechanical properties of $\mathrm{Al}_{2} \mathrm{O}_{3}$ ultra-thin layers, deposited onto suspended graphene membranes are characterized. Prior deposition, $\mathrm{NO}_{2} / \mathrm{TMA}$ treatment is achieved on the graphene to create anchors. ALD is subsequently performed by cycling TMA $/ \mathrm{H}_{2} \mathrm{O}$ doses and graphene is finally etched by oxidation, leaving a continuous and smooth suspended $\mathrm{Al}_{2} \mathrm{O}_{3}$ film only a few atoms thick (typically $2.8 \pm 0.3 \mathrm{~nm}$ ) that is mechanically robust and impermeable to standard gases suggesting pinhole-free layer. ${ }^{211}$ Using standard water/TMA process, continuous sub-2 $\mathrm{nm}$ thin aluminum oxide $\left(\mathrm{AlO}_{\mathrm{x}}\right)$ films are also deposited on supported CVD graphene. ${ }^{212}$ Depending on the deposition conditions, a critical precursor residence time $(>2 \mathrm{~s})$ is needed to obtain conformal nucleation over the entire graphene surface, while shorter residence time results in heterogeneous and selective nucleation. Because of the relative inertness of graphene, prolonged residence time is necessary to counterbalance the slow adsorption kinetics.

ALD performed over various water-soluble polymer layers (polymethyl methacrylate (PMMA), polyvinyl alcohol (PVA), and polyacrylic acid (PAA)) allows growing free-floating $\mathrm{Al}_{2} \mathrm{O}_{3}$ nanosheets by 
removal of the sacrificial polymer substrate. ${ }^{213,214}$ Depending on the nature and molecular weight (MW) of the polymer, the ALD process and the resulting nanosheet are strongly affected. The best results are obtained on PVA of $\mathrm{MW}=16000 \mathrm{~g} / \mathrm{mol}$ that presents a dissolution rate which is a good compromise between complete removal and maintaining the size and flatness of the $\mathrm{Al}_{2} \mathrm{O}_{3}$ layer. It allows the formation of $1 \mathrm{~nm}$ thick $\mathrm{Al}_{2} \mathrm{O}_{3}$ nanosheets with a lateral size-to-thickness ratio exceeding $20000.213,214$

The synthesis of ultra-thin titanium dioxide layers with precise thickness controllability and excellent uniformity remains a significant challenge in the fields of photocatalysis, water splitting, and dyesensitized solar cells. $\mathrm{TiO}_{2}$ nanosheets are fabricated either from Tetrakis (dimethylamido) titanium (TDMAT) and water, ${ }^{215,216}$ or from $\mathrm{TiCl}_{4}$ and deionized (DI) water. ${ }^{213,214}$ In particular, free-standing $\mathrm{TiO}_{2} 2 \mathrm{D}$ nanosheets with various thicknesses are realized using dissolvable sacrificial polymer layer as substrate. ${ }^{213,214,216}$ Zhuiykov et al. ${ }^{215}$ grow conformal atomic-layered $\mathrm{TiO}_{2}$ films with average thickness of $\sim 0.37 \pm 0.04 \mathrm{~nm}$ over 4 inches $\mathrm{SiO}_{2} / \mathrm{Si}$ wafer. As increase of crystallinity is beneficial for the photocatalytic performance, ${ }^{217}$ the $\mathrm{TiO}_{2}$ films are post-annealed to improve their crystallinity and their electrical conductivity. ${ }^{214,215} \mathrm{TiO}_{2}$ films annealed at $150{ }^{\circ} \mathrm{C}$ show widening of their bandgap to $3.37 \mathrm{eV}$ compared to the reported values for bulk rutile $(3.03 \mathrm{eV})$ and anatase $(3.20 \mathrm{eV}) .{ }^{215} \mathrm{Edy}$ et al. ${ }^{216}$ also demonstrate photocatalytic activity of amorphous free-standing $\mathrm{TiO}_{2}$ nanosheets, for which the photocatalytic performance can be enhanced by increasing the thickness due to rising of the local order.

Hong et al. ${ }^{218}$ succeed to deposit a ZnO monolayer on graphene by enhancing its hydrophilicity with an optimized UV/ozone treatment without deterioration of its lattice. This treatment enables the subsequent ALD epitaxial growth of ZnO on CVD graphene, using DEZ and water. Two dominant misorientation angles $\left(0^{\circ}\right.$ and $\left.30^{\circ}\right)$ are observed during the growth and the misorientation angle of $0^{\circ}$ becomes predominant as the $\mathrm{ZnO}$ monolayer grows as visible in Figure $17 .{ }^{218}$ 


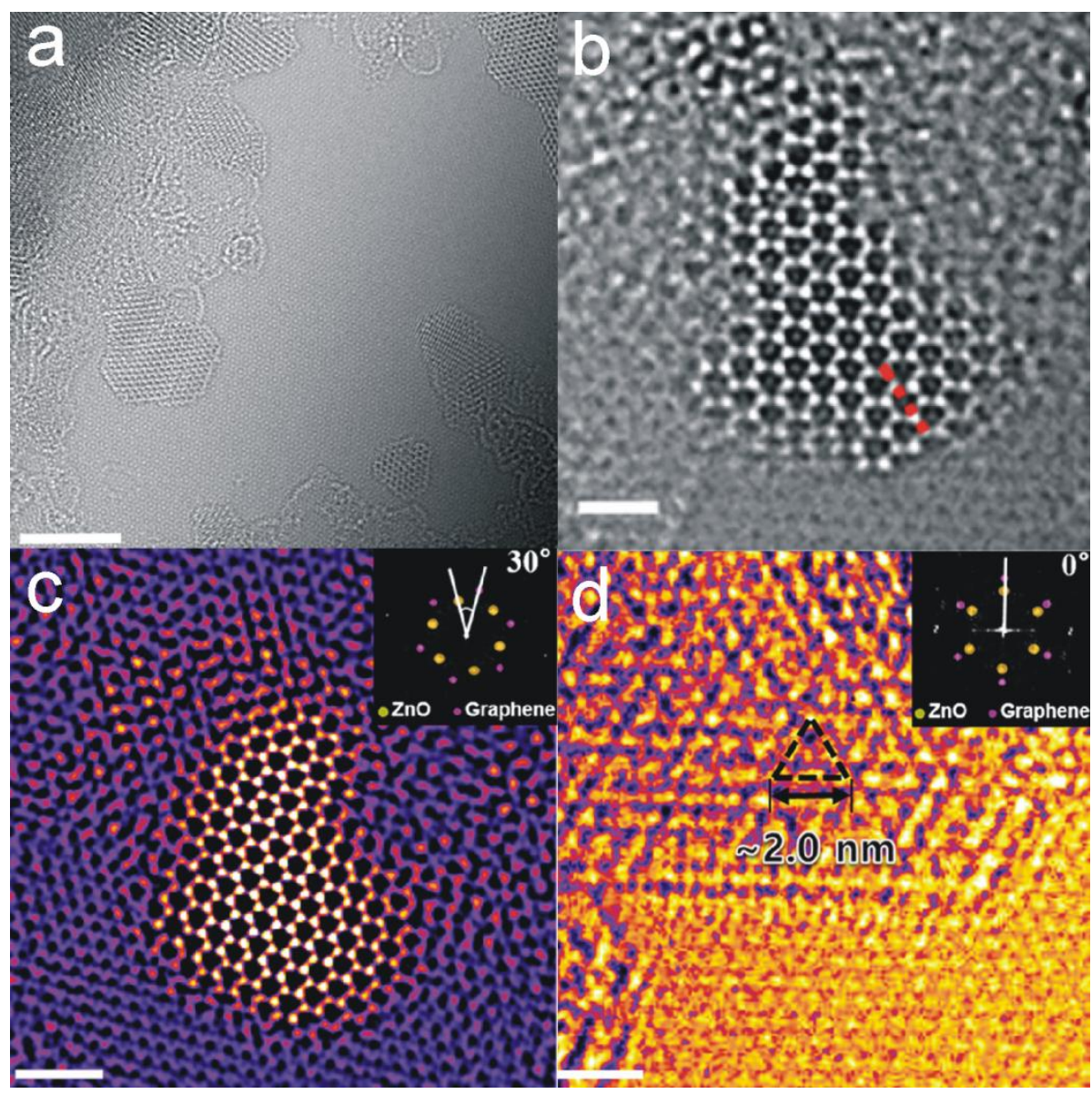

Figure 17. a,b) HRTEM images of $\mathrm{ZnO}$ monolayer deposited on graphene. $\mathrm{c}, \mathrm{d}$ ) atomic resolution showing the respective misorientation of $\mathrm{ZnO}$ toward graphene of c) $30^{\circ}$ and d) $0^{\circ}$. Insets: the corresponding FFT. Reproduced with permission from Ref. $^{218}$

\subsection{Conclusion}

ALD of 2D oxides usually leads to amorphous layers, because of low deposition temperature. When crystalline metal oxides are needed, post-annealing treatment is generally applied, improving the crystalline quality of the film as well as the interface with the substrate. ALD appears a method of choice to fabricate oxide monolayers due to its precise control of film thickness, however only a handful of reports can be found in the literature. The area of $2 \mathrm{D}$ metal oxide by ALD remains thus rather unexplored. 
Table 3. Overview of the reported ALD processes on $2 \mathrm{D}$ metal oxides and their respective applications. Where $P_{\text {atm }}$ is used for atmospheric pressure

\begin{tabular}{|c|c|c|c|c|c|c|c|c|}
\hline Material & Technique & Reactants & Substrate & $\begin{array}{l}\text { Operating } \\
\text { temperature }\end{array}$ & Post-treatment & Crystallinity & Application & Ref. \\
\hline \multirow{16}{*}{$\mathrm{MoO}_{3}$} & \multirow{5}{*}{ PEALD } & \multirow{5}{*}{$\left({ }^{\mathrm{t}} \mathrm{BuN}\right)_{2}\left(\mathrm{NMe}_{2}\right)_{2} \mathrm{Mo} / \mathrm{O}_{2}$} & $\begin{array}{l}\text { Si(100) wafers } \\
\text { with native oxide }\end{array}$ & $50-350^{\circ} \mathrm{C}$ & None & $\begin{array}{l}\text { Amorphous films between } 50 \text { and } 200^{\circ} \mathrm{C} \\
\text { Polycrystalline at temperatures higher } \\
\text { than } 250^{\circ} \mathrm{C}\end{array}$ & $\begin{array}{l}\text { Silicon heterojunction } \\
\text { solar cells }\end{array}$ & 168,179 \\
\hline & & & $\mathrm{SiO}_{2}(300 \mathrm{~nm}) / \mathrm{Si}$ & $150^{\circ} \mathrm{C}$ & Sulfidation to $\mathrm{MoS}_{2}$ & $2 \mathrm{H}-\mathrm{MoS}_{2}$ after annealing at $\mathrm{T}>900^{\circ} \mathrm{C}$ & Integrated circuits & 99 \\
\hline & & & $\mathrm{a}-\mathrm{Si}: \mathrm{H}$ or $\mathrm{SiO}_{x}$ & $100-350^{\circ} \mathrm{C}$ & None & $\begin{array}{c}\text { Amorphous below } 250^{\circ} \mathrm{C} \\
\text { Stable orthorhombic } \alpha \text {-phase above } 250 \\
{ }^{\circ} \mathrm{C}\end{array}$ & $\begin{array}{l}\text { Hole-selective contact of } \\
\text { silicon solar cells }\end{array}$ & 167 \\
\hline & & & $\begin{array}{l}\text { c-Si }(p) \text { wafers with native } \\
\text { oxide }\end{array}$ & $50-200{ }^{\circ} \mathrm{C}$ & $\begin{array}{l}\text { Annealing in } \mathrm{N}_{2} \text { at } 200^{\circ} \mathrm{C} \text { for } \\
10 \mathrm{~min}\end{array}$ & Amorphous & $\begin{array}{c}\text { Silicon heterojunction } \\
\text { solar cells }\end{array}$ & 169 \\
\hline & & & P-doped Si(100) & $\begin{array}{l}\text { Below } 200 \\
{ }^{\circ} \mathrm{C}\end{array}$ & Annealing at $200^{\circ} \mathrm{C}$ for $2 \mathrm{~min}$ & - & $\begin{array}{c}\text { Silicon heterojunction } \\
\text { solar cells }\end{array}$ & 170 \\
\hline & \multirow{11}{*}{ ALD } & \multirow{2}{*}{$\left({ }^{t} \mathrm{BuN}\right)_{2}\left(\mathrm{NMe}_{2}\right)_{2} \mathrm{Mo} / \mathrm{O}_{3}$} & $\mathrm{SiO}_{2}(300 \mathrm{~nm}) / \mathrm{Si}$ & $300^{\circ} \mathrm{C}$ & Sulfidation to $\mathrm{MoS}_{2}$ & $2 \mathrm{H}-\mathrm{MoS}_{2}$ after annealing at $\mathrm{T}>900^{\circ} \mathrm{C}$ & Integrated circuits & 99 \\
\hline & & & $\mathrm{SiO}_{2} / \mathrm{Si}$ & $100-300^{\circ} \mathrm{C}$ & None & - & - & 180 \\
\hline & & \multirow[b]{2}{*}{$\mathrm{Mo}(\mathrm{CO})_{6} / \mathrm{O}_{3}$} & $\mathrm{SiO}_{2}(290 \mathrm{~nm}) / \mathrm{Si}$ & $160^{\circ} \mathrm{C}$. & Sulfidation to $\mathrm{MoS}_{2}$ & - & - & ${ }^{98}$ \\
\hline & & & $\begin{array}{l}\text { Glass, } \mathrm{Si}(111) \text { and } \\
\qquad \mathrm{Al}_{2} \mathrm{O}_{3}(001)\end{array}$ & $152-175^{\circ} \mathrm{C}$ & $\begin{array}{l}\text { Annealing in air at 500-600 } \\
{ }^{\circ} \mathrm{C}\end{array}$ & $\begin{array}{c}\text { Amorphous as-deposited } \\
\alpha \text { - and } \beta-\mathrm{MoO}_{3} \text { phases after annealing at } \\
500^{\circ} \mathrm{C} \\
\text { Phase-pure, highly oriented } \alpha-\mathrm{MoO}_{3} \text { at } \\
600^{\circ} \mathrm{C} \text {. }\end{array}$ & $\begin{array}{c}\text { Organic or sensitized solar } \\
\text { cell }\end{array}$ & 181-183 \\
\hline & & $\mathrm{Mo}(\mathrm{CO})_{6} / \mathrm{H}_{2} \mathrm{O}$ & $\mathrm{Si}(111)$ and $\mathrm{Al}_{2} \mathrm{O}_{3}(001)$ & $152-172{ }^{\circ} \mathrm{C}$ & $\begin{array}{l}\text { Annealing in air at } 500 \text { and } \\
6000^{\circ} \mathrm{C}\end{array}$ & $\begin{array}{c}\text { Amorphous as-deposited } \\
\alpha \text { - and } \beta-\mathrm{MoO}_{3} \text { phases after annealing at } \\
500^{\circ} \mathrm{C} \\
\text { Phase-pure, highly oriented } \alpha-\mathrm{MoO}_{3} \text { at } \\
600^{\circ} \mathrm{C} \text {. }\end{array}$ & - & 182,183 \\
\hline & & $\mathrm{MoO}_{2}\left(\mathrm{R}_{2} \mathrm{AMD}\right)_{2}\left(\mathrm{R}=\mathrm{Cy} ;{ }^{\mathrm{i}} \mathrm{Pr}\right) / \mathrm{O}_{3}$ & Si wafers & $150-225^{\circ} \mathrm{C}$ & None & Amorphous & - & 185 \\
\hline & & $\mathrm{MoO}_{2}(\mathrm{acac})_{2} / \mathrm{H}_{2} \mathrm{O}$ & Alumina powder & $125-200^{\circ} \mathrm{C}$ & $\begin{array}{c}\text { Annealing in } 10 \% \mathrm{O}_{2} / \mathrm{N}_{2} \text { at } \\
650^{\circ} \mathrm{C} \text { for } 6 \mathrm{~h}\end{array}$ & - & Catalysis & 186 \\
\hline & & $\mathrm{Mo}\left(\mathrm{O}^{\mathrm{i}} \mathrm{Pr}\right)_{5} / \mathrm{H}_{2} \mathrm{O}$ & Alumina powder & $\begin{array}{c}70,100,150 \\
{ }^{\circ} \mathrm{C}\end{array}$ & $\begin{array}{c}\text { Annealing in } 10 \% \mathrm{O}_{2} / \mathrm{N}_{2} \text { at } \\
650^{\circ} \mathrm{C} \text { for } 6 \mathrm{~h}\end{array}$ & - & Catalysis & 186 \\
\hline & & $\mathrm{BEBMo} / \mathrm{H}_{2} \mathrm{O}$ & Alumina powder & $135-160^{\circ} \mathrm{C}$ & $\begin{array}{l}\text { Annealing in } 10 \% \mathrm{O}_{2} / \mathrm{N}_{2} \text { at } \\
650^{\circ} \mathrm{C} \text { for } 6 \mathrm{~h}\end{array}$ & - & Catalysis & 186 \\
\hline & & $\mathrm{MOTSMA} / \mathrm{O}_{3}$ & $\begin{array}{c}\text { Double-sided-polished } \\
\text { Si(100) }\end{array}$ & $250-300^{\circ} \mathrm{C}$ & None & - & - & 187 \\
\hline & & $\mathrm{Si}_{2} \mathrm{H}_{6} / \mathrm{MoF}_{6} / \mathrm{UV}$ ozone & indium tin oxide (ITO) & $200^{\circ} \mathrm{C}$ & $\begin{array}{c}\text { Spin-coating of photoactive } \\
\text { ink, annealing at } 120^{\circ} \mathrm{C} \text { for } 5 \\
\text { min, thermal evaporation of } \\
\text { a Ca/Al cathode } \\
\end{array}$ & - & $\begin{array}{l}\text { Anode buffer layer in } \\
\text { organic photovoltaic cells }\end{array}$ & 171 \\
\hline $\mathrm{CoMoO}_{4}$ & ALD & $\begin{array}{c}\mathrm{CoCp}_{2}, \mathrm{Co}(\text { thd })_{2} \text { or } \mathrm{Mo}(\mathrm{CO})_{6} / \mathrm{O}_{3}, \mathrm{H}_{2} \mathrm{O} \text { or } \\
\left(\mathrm{O}_{3}+\mathrm{H}_{2} \mathrm{O}\right) .\end{array}$ & $\begin{array}{c}\mathrm{Si}(100), \alpha-\mathrm{Al}_{2} \mathrm{O}_{3}(001) \text { and } \\
\alpha-\mathrm{SiO}_{2}(001) \text {. }\end{array}$ & $167^{\circ} \mathrm{C}$ & $\begin{array}{l}\text { Annealing in air at } 600^{\circ} \mathrm{C} \text { for } \\
6 \text { or } 10 \mathrm{~min}\end{array}$ & $\begin{array}{c}\text { Amorphous as-deposited } \\
\text { Crystallize into } \beta \text {-CoMoO } \mathrm{CoO}_{4} \text { under } \\
\text { annealing }\end{array}$ & - & 184 \\
\hline
\end{tabular}




\begin{tabular}{|c|c|c|c|c|c|c|c|c|}
\hline \multirow{9}{*}{$\mathrm{WO}_{3}$} & $\begin{array}{l}\text { ALD- } \\
\text { based } \\
\text { process }\end{array}$ & $\mathrm{W}(\mathrm{CO})_{6} / \mathrm{H}_{2} \mathrm{O}_{2}$ & $\mathrm{TiO}_{2}$ powders & $180-200^{\circ} \mathrm{C}$ & $\begin{array}{l}\text { Ex-situ annealing in air for } 2 \mathrm{~h} \\
\text { at constant temperature of } \\
\text { either } 500 \text { or } 750^{\circ} \mathrm{C}\end{array}$ & Amorphous & Catalysis & 198 \\
\hline & \multirow{6}{*}{ ALD } & \multirow[b]{2}{*}{$\mathrm{W}(\mathrm{CO})_{6} / \mathrm{O}_{3}$} & $\mathrm{Si}(100)$ & $195-205^{\circ} \mathrm{C}$ & $\begin{array}{c}\text { Annealing at } 600-1000^{\circ} \mathrm{C} \text { in } \\
\text { oxygen or nitrogen }\end{array}$ & $\begin{array}{c}\text { Partially crystalline as-deposited } \\
\text { Crystallinity enhanced after annealing }\end{array}$ & - & 197 \\
\hline & & & $\mathrm{Si}(111)$ & $190^{\circ} \mathrm{C}$ & $\begin{array}{c}\text { Annealing at } 600^{\circ} \mathrm{C} \text { for } 1 \\
\text { hour at } P_{\text {atm }}\end{array}$ & $\begin{array}{c}\text { Amorphous as-deposited } \\
\text { Crystallize into monoclinic } \mathrm{WO}_{3} \text { upon } \\
\text { annealing. }\end{array}$ & Solar cell & 196 \\
\hline & & $\mathrm{W}(\mathrm{CO})_{6} / \mathrm{H}_{2} \mathrm{O}$ & p-type Si(100) & $150-320^{\circ} \mathrm{C}$ & Annealing at $P_{\text {atm }}$ with $\mathrm{O}_{2}$ & $\begin{array}{c}\text { Amorphous layer completely crystallizes } \\
\text { into polycrystalline film under post- } \\
\text { annealing }\end{array}$ & - & 199,200 \\
\hline & & \multirow{2}{*}{$\left({ }^{t} \mathrm{BuN}\right)_{2} \mathrm{~W}\left(\mathrm{NMe}_{2}\right)_{2} / \mathrm{H}_{2} \mathrm{O}$} & ITO-coated glass & $250-350^{\circ} \mathrm{C}$ & $\begin{array}{l}\text { Annealing at } 550^{\circ} \mathrm{C} \text { under } \\
100 \mathrm{sccm} \text { of } \mathrm{O}_{2} \text { at } \mathrm{P}_{\mathrm{atm}} \text { for } 1 \mathrm{~h}\end{array}$ & Crystalline & Water splitting & 163 \\
\hline & & & $\mathrm{SiO}_{2} / \mathrm{Si}$ wafers & $300-350^{\circ} \mathrm{C}$ & $\begin{array}{c}\text { Annealing at } 200-400^{\circ} \mathrm{C} \text { for } \\
1 \mathrm{~h}\end{array}$ & $\begin{array}{c}\text { Amorphous as-deposited } \\
\text { Crystallinity increases with temperature }\end{array}$ & Photodetectors & $205-207$ \\
\hline & & $\mathrm{WO}_{2}\left({ }^{\mathrm{t}} \mathrm{BuAMD}\right)_{2} / \mathrm{H}_{2} \mathrm{O}$ & B-doped, n-type Si(100) & $120-270^{\circ} \mathrm{C}$ & $\begin{array}{c}\text { Annealing at } 500^{\circ} \mathrm{C} \text { for } 6 \mathrm{~h} \text { in } \\
\text { static air }\end{array}$ & $\begin{array}{c}\text { Crystallize as } \mathrm{WO}_{3} \text { nanowires upon } \\
\text { annealing }\end{array}$ & Heterogeneous catalysis & 208 \\
\hline & PEALD & $\mathrm{WF}_{6} / \mathrm{H}_{2} \mathrm{O}$ & $\mathrm{Si}(111)$ & $30-180^{\circ} \mathrm{C}$ & None & Amorphous & - & 202 \\
\hline & HWALD & W filament $/ \mathrm{O}_{2}, \mathrm{~N}_{2}, \mathrm{H}_{2}$ or $\mathrm{H}_{2}-\mathrm{N}_{2}$ gas & $\mathrm{Si}$ & $\begin{array}{l}\text { W filament } \\
\text { at } 660^{\circ} \mathrm{C} .\end{array}$ & None & Amorphous & - & 209 \\
\hline $\mathrm{W}_{2} \mathrm{O}_{3}$ & ALD & $\mathrm{W}_{2}\left(\mathrm{NMe}_{2}\right)_{6} / \mathrm{H}_{2} \mathrm{O}$ & Si(100) & $140-200^{\circ} \mathrm{C}$ & None & Amorphous & - & 210 \\
\hline \multirow[b]{2}{*}{$\mathrm{Al}_{2} \mathrm{O}_{3}$} & \multirow[b]{2}{*}{ ALD } & \multirow[b]{2}{*}{$\mathrm{TMA} / \mathrm{H}_{2} \mathrm{O}$} & $\begin{array}{l}\mathrm{NO}_{2} \text { treated suspended } \\
\text { graphene membranes }\end{array}$ & $180^{\circ} \mathrm{C}$ & None & Amorphous & $\begin{array}{c}\text { Quasi-2D } \\
\text { electromechanical } \\
\text { structures } \\
\end{array}$ & 211 \\
\hline & & & $\begin{array}{l}\text { Sacrificial polymers : } \\
\text { PMMA, PVA, PAA }\end{array}$ & $90^{\circ} \mathrm{C}$ & $\begin{array}{c}\text { Template removal } \\
\text { Annealing in air for } 1 \mathrm{~h} \text { at } \\
450-500^{\circ} \mathrm{C} \text { to remove } \\
\text { residual polymer }\end{array}$ & Amorphous & Photocatalysis & 213,214 \\
\hline $\mathrm{AlO}_{\mathrm{x}}$ & ALD & $\mathrm{TMA} / \mathrm{H}_{2} \mathrm{O}$ & $\begin{array}{c}\text { Graphene } / \mathrm{Cu} \\
\text { Graphene } / \mathrm{Ge} \text {, and } \\
\text { Graphene } / \mathrm{SiO}_{2}\end{array}$ & $200^{\circ} \mathrm{C}$ & None & - & - & 212 \\
\hline \multirow{4}{*}{$\mathrm{TiO}_{2}$} & PEALD & $\mathrm{TiCl}_{4} / \mathrm{H}_{2} \mathrm{O}$ or $\mathrm{O}_{2}$ & $\mathrm{Si}(111)$ & $30-180^{\circ} \mathrm{C}$ & None & $\begin{array}{l}\text { Amorphous for temperatures up to } 90^{\circ} \mathrm{C} \\
\text { Crystallinity appears at } 180^{\circ} \mathrm{C}\end{array}$ & - & 202 \\
\hline & \multirow{3}{*}{ ALD } & \multirow[b]{2}{*}{ TDMAT/ $\mathrm{H}_{2} \mathrm{O}$} & Sacrificial PVA on Si & $150^{\circ} \mathrm{C}$ & Template removal & Amorphous & Photocatalysis & 216 \\
\hline & & & $\mathrm{SiO}_{2} / \mathrm{Si}$ & $250^{\circ} \mathrm{C}$ & $\begin{array}{l}\text { Annealing at } 150-1100^{\circ} \mathrm{C} \text { in } \\
\text { air for } 2 \mathrm{~h}\end{array}$ & $\begin{array}{c}\text { As-deposited amorphous, annealed } \\
\text { crystalline: } \mathrm{T}>280^{\circ} \mathrm{C} \text { anatase } \\
\mathrm{T}>400^{\circ} \mathrm{C} \text { rutile }\end{array}$ & - & 215 \\
\hline & & $\mathrm{TiCl}_{4} / \mathrm{H}_{2} \mathrm{O}$ & $\begin{array}{l}\text { Sacrificial polymers : } \\
\text { PMMA, PVA, and PAA }\end{array}$ & $100^{\circ} \mathrm{C}$ & $\begin{array}{l}\text { Template removal } \\
\text { Annealing in air for } 1 \mathrm{~h} \text { at } \\
450-500^{\circ} \mathrm{C} \text { to remove } \\
\text { residual polymer }\end{array}$ & Amorphous & Photocatalysis & 213,214 \\
\hline $\mathrm{ZnO}$ & ALD & $\mathrm{DEZ} / \mathrm{H}_{2} \mathrm{O}$ & Graphene & $200^{\circ} \mathrm{C}$ & None & $\begin{array}{l}\text { Single layer } \mathrm{ZnO} \text { on graphene presents } \\
\text { graphene-like structure instead of } \\
\text { expected wurtzite structure }\end{array}$ & Optoelectronics & 218 \\
\hline
\end{tabular}




\section{Applications of ALD and ALET 2D materials}

2D materials fabricated using atomic layer techniques have found applications in different domains that can be divided into three main categories, i.e. electronics, energy and environmental applications. The purpose of this review is neither to discuss in details about the applications nor to give a direction about them. For that the reader can refer to the roadmap ${ }^{219}$ published by the European graphene flagship for deeper details and perspective on 2D material applications. This brief section introduces only few key implementations reported so far. The table 4 aims to give a concise and non-exhaustive overview of the demonstrated performances of reported devices based on ALD 2D materials.

It should be first pointed out that only a handful of works have reported functional devices based on ALD/ALET 2D materials. Among them, only a tens deals with electronics application, while it is the main usually reported field for 2D materials. In particular, top or bottom gate FET devices have been fabricated from ALD/ALET TMDs. ${ }^{96,101,116,125,128,132}$ Field effect mobility higher than that of CVD layers has been measured, highlighting the added value of the atomic layer techniques. ${ }^{128}$ Furthermore, ALD fabricated $\mathrm{WS}_{2} / \mathrm{SnS}^{125}$ and $\mathrm{MoS}_{2} / \mathrm{WSe}_{2}{ }^{95}$ heterostructures have been implemented, respectively, as FET and $p-n$ diode devices. The sector of energy is also concerned by the emergence of $2 D$ materials and it represents the main application area of such ALD and ALET layers, especially regarding solar cells and Li-ion batteries. Indeed, they both take advantage of low temperature processing, highly conformal ultra-thin layers deposition and compatibility with 3D structures. Light absorbers, anodes and electrocatalyst have been fabricated using atomic layer techniques, tested and, in the two first cases, successfully implemented in solar cells and Li-ion batteries. For instance, ultra-thin layers of $\mathrm{Al}_{2} \mathrm{O}_{3}$ have proved their efficiency in solar cells by passivating the surface of c-Si wafers and thus reducing the recombination velocity at the interface. ${ }^{220}$ For Li-ion batteries, stacking of high quality thin films is required on 3D-structured substrates to allow a storage capacity sufficient enough to miniaturize the battery for portable electronics. Furthermore, various environmental applications have been reported. On the one side, chalcogenide and oxide layers have been investigated as sensitive layers in detection devices. In particular, gas sensors based on $\mathrm{Nb}: \mathrm{MoSe}_{2}{ }^{119}$ as well as uncoated and $\mathrm{Ag}$ nanowire decorated $\mathrm{WS}_{2}$ films ${ }^{129}$ have been investigated, nonetheless they do not always reach the actual performance toward $\mathrm{NO}_{2}$ and acetone sensing. Photodetectors fabricated from $\mathrm{WO}_{3}$ layer exhibit competitive characteristics specifically regarding the response time. Indeed, Hai et al. ${ }^{207}$ achieved a response time to UV of less than $0.04 \mathrm{~ms}$ corresponding to one of the best values reported after graphene devices. On the other side, photodegradation of organics as methylorange and hydrogenation of azobenzene and its derivatives have been successfully realized using self-supported ultra-thin oxide sheets ${ }^{214,216}$ and $\mathrm{FeS}_{x}$ coated $\mathrm{Al}_{2} \mathrm{O}_{3}$ powder, ${ }^{92}$ 
respectively. For instance, conversion rate above $90 \%$ and selectivity superior to $99 \%$ are observed for the catalytic reaction of azobenzene. Finally, it can also be mentioned that $\mathrm{WS}_{2}$ and $\mathrm{h}-\mathrm{BN}$ have been originally applied as solid lubricant coating. ${ }^{60,120-122,126}$ 
Table 4. overview of the demonstrated performances of reported devices based on ALD 2D materials

\begin{tabular}{|c|c|c|c|c|c|c|c|c|c|c|c|c|}
\hline \multirow{4}{*}{ Material } & \multirow{4}{*}{ Device structures } & \multicolumn{10}{|c|}{ Applications } & \multirow[t]{4}{*}{$\operatorname{Re}$} \\
\hline & & & & & & Electr & application & & & & & \\
\hline & & \multicolumn{4}{|c|}{ FET } & \multirow{2}{*}{$\begin{array}{c}\text { PN diode } \\
\text { Leakage } \\
\text { current }(\mathrm{A})\end{array}$} & \multicolumn{5}{|c|}{ MIVs } & \\
\hline & & $\begin{array}{l}\text { Mobility } \\
\left(\mathrm{cm}^{2} / \text { V.s }\right)\end{array}$ & $\begin{array}{l}\text { Dirac Voltage } \\
\text { (V) }\end{array}$ & $\mathrm{I}_{\mathrm{ON}} / \mathrm{I}_{\mathrm{OFF}}$ & $\begin{array}{l}\text { Subthreshold } \\
\text { swing (V/dec) }\end{array}$ & & $\begin{array}{c}\text { Transient } \\
\text { response time } \\
\text { (ns) }\end{array}$ & $\begin{array}{c}\text { Non } \\
\text { linearity }\end{array}$ & $\begin{array}{c}\text { Capacitance } \\
\text { (pF) }\end{array}$ & $\begin{array}{c}\text { Leakage } \\
\text { current }(\mathrm{pA})\end{array}$ & $\begin{array}{l}\text { Protection } \\
\text { voltage (V) }\end{array}$ & \\
\hline \multirow[b]{2}{*}{ h-BN } & $\begin{array}{c}\text { Top-gate } 1 \mathrm{~L} \\
\text { graphene FET on h- } \\
\text { BN }\end{array}$ & 4,923 & -0.2 & $10^{8}$ & 0.36 & - & - & - & - & - & - & 67 \\
\hline & $\begin{array}{c}\text { Micron-sized } \\
\text { spherical Al particles } \\
\text { coated with } 12,5 \\
\text { nm-thick BN film }\end{array}$ & - & - & - & - & - & 0.3 & 233 & 44.3 at $1 \mathrm{kHz}$ & $\begin{array}{c}50 \text { at } 100 \mathrm{~V} \\
\mathrm{dc}\end{array}$ & $\begin{array}{l}1010 \text { in } \\
\text { response to a } \\
20 \mathrm{kV} \\
\text { transient }\end{array}$ & 72 \\
\hline \multirow{6}{*}{$\mathrm{MoS}_{2}$} & $\begin{array}{c}1 \mathrm{~L} \mathrm{MoS} \text { top-gate } \\
\text { FET }\end{array}$ & 0.2 & - & - & - & - & - & - & - & - & - & 95 \\
\hline & $\begin{array}{c}\text { Back gated FET on } \\
\text { bilayer films of } \mathrm{MoS}_{2}\end{array}$ & 1 & - & - & - & - & - & - & - & - & - & 101 \\
\hline & $\begin{array}{c}\text { Bottom-gate } \\
\text { exfoliated 2L MoS } \\
\text { FET } \\
\end{array}$ & 5.78 & - & - & - & - & - & - & - & - & - & \multirow{4}{*}{95} \\
\hline & $\begin{array}{c}\text { Bottom-gate } \\
\text { exfoliated } 1 \mathrm{~L} \mathrm{MoS} \\
\text { FET }\end{array}$ & 2.65 & - & - & - & - & - & - & - & - & - & \\
\hline & $\begin{array}{c}\text { Bottom-gate } \\
\text { exfoliated } 2 \mathrm{~L} \mathrm{MoS} 2 \\
\text { FET after one-cycle } \\
\mathrm{MoS}_{2} \text { ALET under } \\
\text { monolayer etching } \\
\text { condition }\end{array}$ & 2.03 & - & - & - & - & - & - & - & - & - & \\
\hline & $\begin{array}{c}\text { Bottom-gate } \\
\text { exfoliated } 2 \mathrm{~L} \mathrm{MoS} 2 \\
\text { FET after one-cycle } \\
\mathrm{MoS}_{2} \text { ALET under } \\
\text { Ar+ ion } \\
\text { overexposure } \\
\text { condition }\end{array}$ & 2.02 & - & - & - & - & - & - & - & - & - & \\
\hline \multirow[t]{2}{*}{$\mathrm{WS}_{2}$} & $\begin{array}{l}\text { Top-gate FET using a } \\
\text { high-k dielectric } \\
\text { gate insulator }\end{array}$ & 3.9 & - & - & 0.6 & - & - & - & - & - & - & 128 \\
\hline & $\begin{array}{c}\text { Back-gate FET of } \\
W_{2}\end{array}$ & 12 & - & - & - & - & - & - & - & - & - & \\
\hline $\mathrm{WS}_{2} / \mathrm{SnS}$ & $\begin{array}{l}\text { Heterojunction } \\
\text { stack consisting } 3 \mathrm{~L} \\
\mathrm{WS}_{2} / 3 \mathrm{~L} \mathrm{SnS}\end{array}$ & $\begin{array}{l}48(n- \\
\text { FET) } \\
20(p- \\
\text { FET) }\end{array}$ & - & - & - & - & - & - & - & - & - & 125 \\
\hline $\mathrm{WSe}_{2}$ & $\begin{array}{l}\text { Back-gated FET with } \\
\text { Pd electrodes }\end{array}$ & $\begin{array}{l}531(\mathrm{n}- \\
\text { FET) }\end{array}$ & - & $10^{5}$ & - & - & - & - & - & - & - & 132 \\
\hline
\end{tabular}




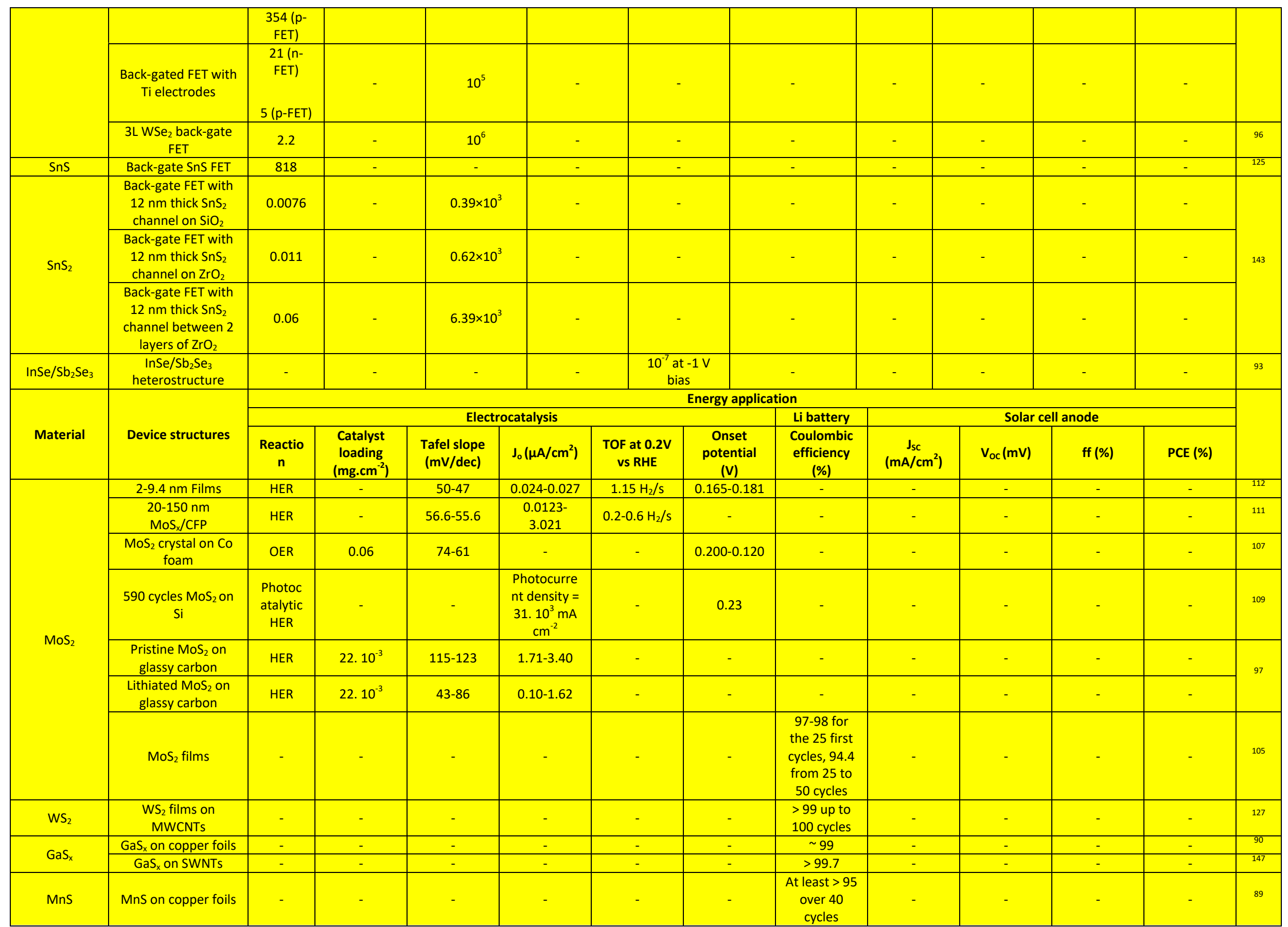




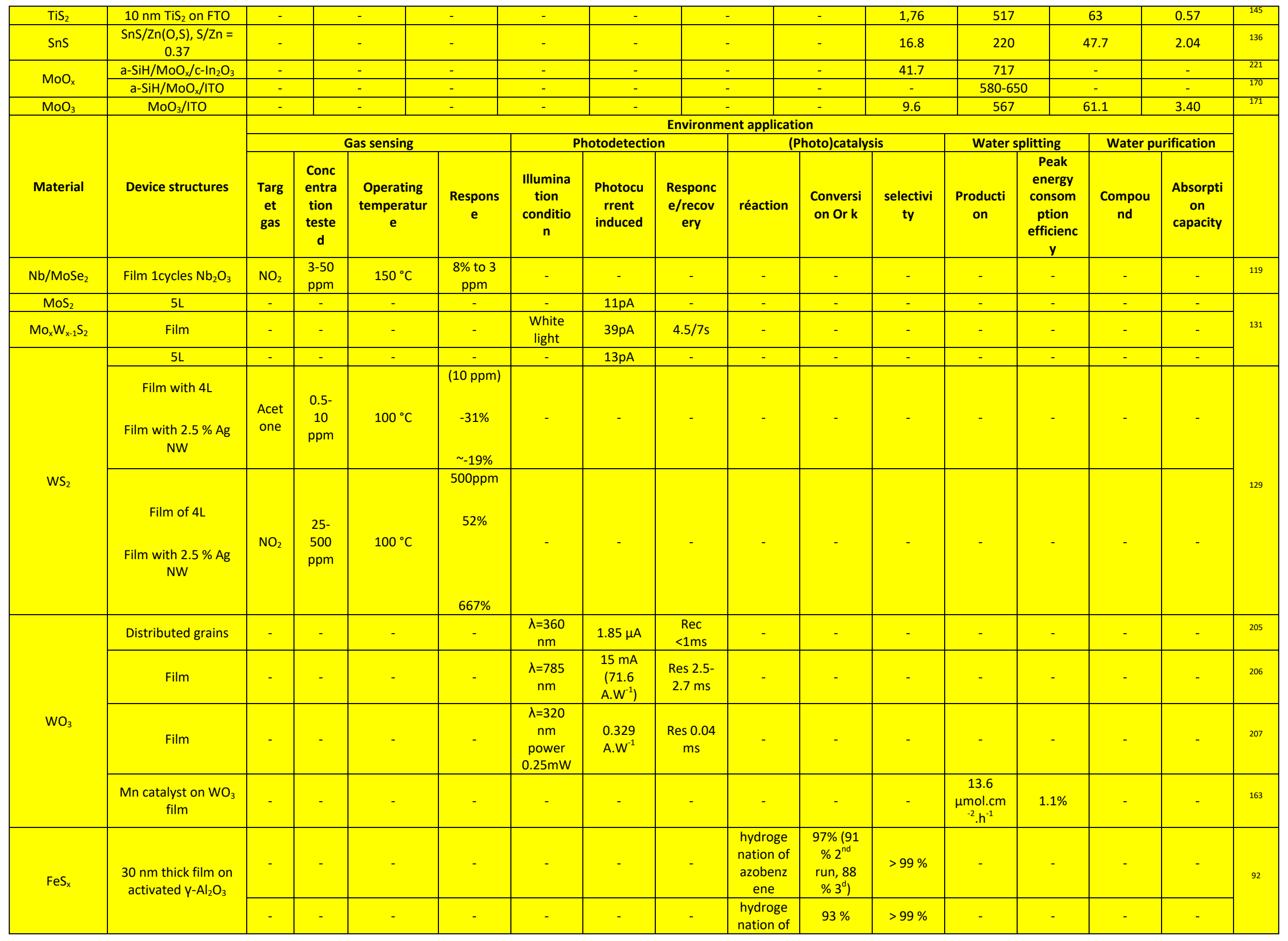




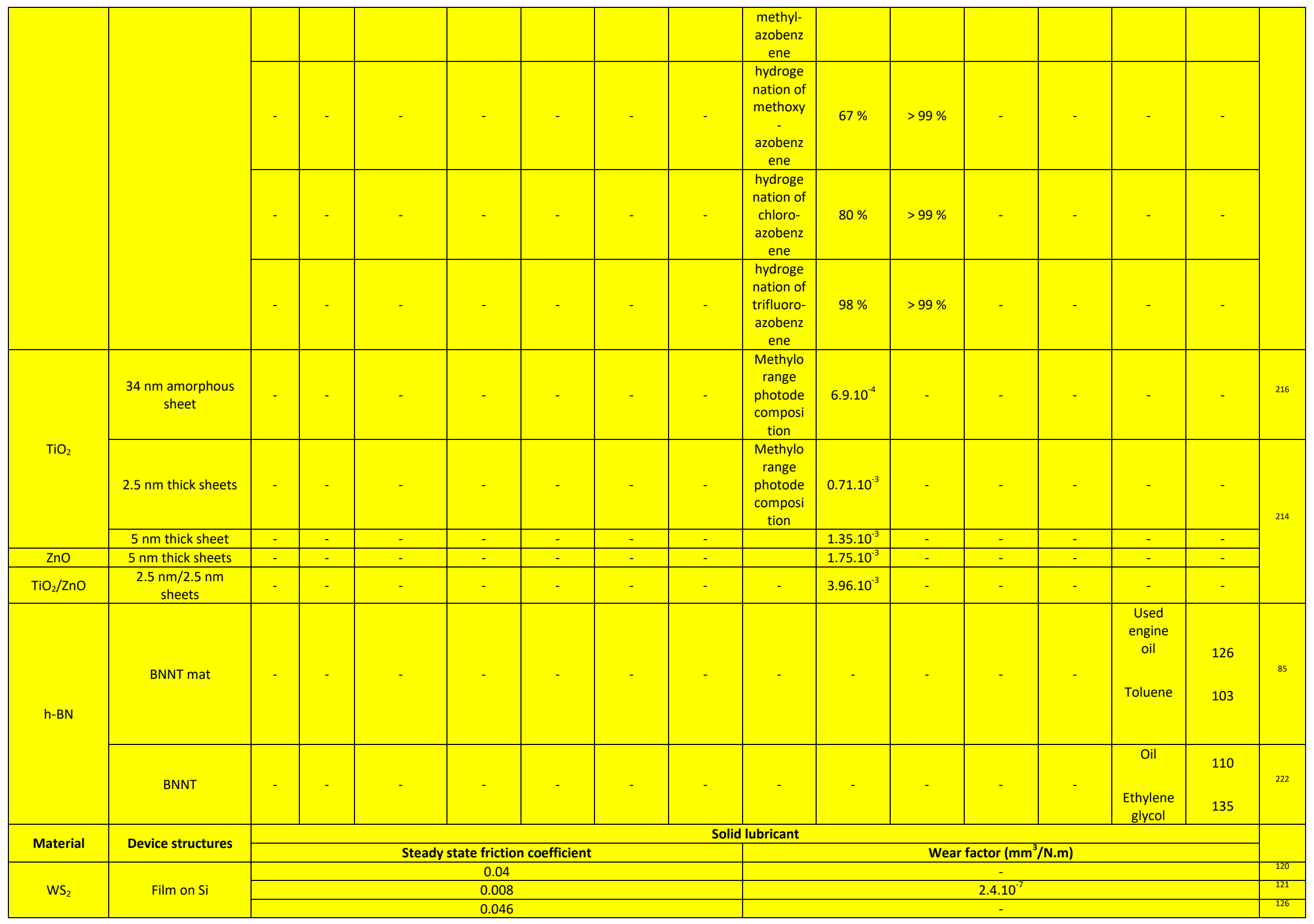




\section{Conclusion, perspectives and challenges}

Atomic layer deposition has been successfully employed for fabricating various 2D materials, like graphene, h-BN, TMDs and oxides. Benefiting to the ALD's fine thickness control, good homogeneity and conformality, 2D materials have precisely been fabricated onto various substrates. The obtained structures have found applications in different fields as catalysis, FET devices, solar cells, batteries, water splitting, sensors and water treatment. Nevertheless, post-annealing is often necessary to reach the desired crystallinity and it should be highlighted that the involved chemistry remains rather poor because of lack of suited precursor. Indeed, as an example, BN and stable TMDs are mainly grown from $\mathrm{NH}_{3}$ - and $\mathrm{H}_{2} \mathrm{~S}$-based process, respectively. Furthermore, the lack of reactivity of the basal planes might strongly affect the growth and successful fabrication of VdW heterostructures is determined by the ability of the second layer to nucleate on the first one.

To address these drawbacks, few groups have already developed alternative routes based either on novel precursors and chemical route like PDCs and thiolate intermediate or on innovative ALD approaches as EEALD and HWALD. Especially, two-step processes as well as enhanced or HW ALD enable low deposition temperature of $\mathrm{BN}$ and TMDs paving the way to coating of sensitive/organic substrates. Nonetheless, it should be mentioned that PEALD and EEALD suffer from lack of homogeneity on high aspect ratio surfaces and so are currently limited to flat substrates. On the other hand, taking advantage of the absence of dangling bonds, SLS has been introduced for accurately controlling the number of grown TMDs from one to few layers. Few ALD VdW stacks have also been reported. Their relative crystalline orientation is governed by the lattice mismatch between both materials and surface activation of the former one might be needed. For instance, local epitaxial relationship has been observed between $\mathrm{Bi}_{2} \mathrm{Te}_{3}$ and $\mathrm{Sb}_{2} \mathrm{Te}_{3}$, which display similar crystal structure, while misalignment is noted between hexagonal $\mathrm{WS}_{2}$ and orthorhombic SnS. Furthermore, whereas direct ALD growth is realized on ALD-Sb ${ }_{2} \mathrm{Se}_{3}$ and $-\mathrm{WS}_{2}$, pre-treatment is required on $\mathrm{Sb}_{2} \mathrm{Te}_{3}$ to initiate the nucleation of a second 2D material because of its lack of surface active site.

Another emerging strategy consists on a top-down process: the atomic layer etching. ALET allows layer by layer removal of 2D materials. It has succeeded in obtaining one to few monolayers of graphene and $\mathrm{MoS}_{2}$. Excepted that good quality starting material is needed, it turns out to be a powerful and facile technique. Its ability for patterning with resolution down to $100 \mathrm{~nm}$ makes it very promising for development of groundbreaking 2D based devices.

In conclusion, atomic layer techniques prove to be efficient for fabricating controlled number of 2D materials and VdW heterostructures, despite some nucleation and crystallinity issues and their confidential use. With the constant rising of 2D materials, one can expect that ALD and ALET will take position in the field. ALD progresses will rely on development of precursor and alternative chemistry, 
enhancement of the quality of as-grown films and managing the surface reactivity. In particular, challenges remain regarding the nucleation and adhesion of the thin film as well as control of the impurity content. Developing ALD of 2D materials requires understanding of surface reaction mechanisms, interface formation and film structure.

Surface chemistry represents a key point for the advancement of ALD of 2D materials, especially because the inertness of their basal plans is expected to inhibit their growth and thus formation of VdW heterostructures. Such studies can be achieved for instance by in situ analyses ${ }^{223-225}$ eventually combined with modelling of the growth. The report of Cadot et al. ${ }^{115}$ on the reaction mechanism of $\mathrm{MoS}_{2}$ growth illustrates the interest of such investigation in view of controlling the thickness, uniformity and crystallinity of the final material. Understanding of the anchoring of the first amorphous 2D layer on reference substrate as well as its crystallization process is evidenced using in operando characterization combined with ex-situ analyses. Knowledge of the interface formation is crucial for further 2D stacking. The nucleation step and the epitaxial growth have to be controlled in order to avoid or tune eventual interface layer and defects at the interface as well as the mechanical stress and the lattice deformation that can occur in van der Waals heterostructures. Such stacking imperfections have drastic effects on the physical properties ${ }^{125}$ and must be addressed for implementation of the final structures. It has been recently demonstrated that lattice mismatch and interactions between the stacked layers induce strains that affect their electronic properties. The relative rotation angle between both layers directly influences the elastic deformations and thus its tuning permits tailoring the electronic properties of the whole structure. ${ }^{226}$ Controlling stack orientation would allow the fabrication of materials that have not yet been explored and provide new pathways for 2D electronic device fabrication, such as field effect transistors, memory capacitors, resistive switching memory cells and microelectromechanical systems. To enable controlled growth of successive ALD 2D layers, surface functionalization (chemical or physical one) might be required. Despite of eventual van der Waals induced growth, ${ }^{93}$ lack of dangling bonds on the 2D surface may inhibit the subsequent deposition. ${ }^{158}$ Therefore specific functionalization might be realized in order to allow the ALD nucleation while preserving the intrinsic properties of the underlying material, as previously reported for ALD on carbon materials and more specifically on graphene. $^{155}$

Furthermore, achieving suitable crystallinity and stoichiometry remains challenging depending on the deposited materials. While well crystallized chalcogenides are often observed as ALD deposited, graphene, $\mathrm{h}-\mathrm{BN}$ and 2D oxides usually need high temperature post-annealing, even though it reveals sometimes insufficient for obtaining good film quality. On the one side, ALD of graphene and h-BN will require further development and novel precursors enabling good crystallization. On the other side, ALD 2D oxides suffer from lack of control of the final stoichiometry which certainly needs 
improvement in tailoring the initial precursors. In a more general view, explore novel ALD precursor chemicals will allow expanding the ALD technique in the field of 2D materials. Indeed, several predicted materials, as silicene, germanene, or also phosphorene, as well as telluride 2D materials have not yet been ALD deposited due to the lack of suitable precursors. It should also be pointed out that even though graphene is the most studied 2D material, its ALD is still challenging, the only ALD process available ${ }^{45}$ leading to material quality inferior to the one obtained using CVD technique. Regarding the panel of possible applications, ranging from electronics and energy to biology and medicine, ALD is very attractive as it allows conformal deposition on various substrates (polymer, biological, metal, etc.) even with high aspect ratio. In particular, atomic layer techniques display a great potential in the development of advanced biomedical materials, as they allow coatings, functionalization and modification of heat-sensitive substrates such as polymers, biological and organic materials or even complex structures, such as woven fabrics, fiber mats and bundles. ${ }^{227-229}$ It is a safe bet that ALD/ALET could play a crucial role in the fabrication of bio-microelectromechanical systems (bio-MEMS) like implants, neuro-surgical tools or catheter-blood sensors that need to be protected from their fluidic environment without affecting too much the biological process that they are measuring in the meantime. However, depending on the 2D materials, the deposition temperature can vary from near room temperature up to $500{ }^{\circ} \mathrm{C}$ and high temperature annealing might even be required. On the one side, one can foresee that reducing the growth temperature for TMDs down to $100{ }^{\circ} \mathrm{C}$ will open new and very attractive possibilities in flexible devices, transparent electronics and biological fields, for instance. Attempts to overcome this current limitation will certainly drive the emergence of alternative processes as PEALD, HWALD, EEALD as well as of novel precursor families. Another important issue to be addressed is the formation of high quality h-BN at mid temperature, which will pave the way to flexible graphene electronics. On the other side, conformal deposition of 2D layers on highly structured supports as trenches, nanotubes, particles, offers large surface area and thus strong potentialities in electrodes, sensors, catalysis, Li-ion batteries or solar cell domains.

In addition to ALD, SLS and ALET are two other promising routes. In particular, $\mathrm{MoS}_{2}$ and $\mathrm{WSe}_{2}$ have been successfully fabricated using SLS with accurate control of the number of layers, ${ }^{95,96}$ proving its potentiality in 2D material synthesis. Efforts should certainly be made in this direction for extending SLS use in graphene and other TMDs fabrication. The extension of ALET to the whole 2D family will require good starting material quality and selective reactions. These challenges together with increase of the reaction kinetic and preservation of the final layer characteristics need to be addressed.

Finally, one of the main challenges to face is the transfer of the 2D materials into the industry. Currently, only graphene is under development mainly using CVD technique. ${ }^{219}$ One can envisage 
that progresses of atomic layer techniques of 2D materials, in particular direct growth of large scale layers without grain boundaries on integrable devices, will promote their industrialization.

\section{References}

1. Novoselov, K. S. et al. Electric field effect in atomically thin carbon films. science 306, 666-669 (2004).

2. Mas-Ballesté, R., Gómez-Navarro, C., Gómez-Herrero, J. \& Zamora, F. 2D materials: to graphene and beyond. Nanoscale 3, 20-30 (2011).

3. Butler, S. Z. et al. Progress, Challenges, and Opportunities in Two-Dimensional Materials Beyond Graphene. ACS NANO 7, 2898-2926 (2013).

4. Choi, W. et al. Recent development of two-dimensional transition metal dichalcogenides and their applications. Mater. Today (2017). doi:10.1016/j.mattod.2016.10.002

5. Xu, M., Liang, T., Shi, M. \& Chen, H. Graphene-Like Two-Dimensional Materials. Chem. Rev. 113, 3766-3798 (2013).

6. Liu, Y. et al. Van der Waals heterostructures and devices. Nat. Rev. Mater. 1, 16042 (2016).

7. Irani, R., Naseri, N. \& Beke, S. A review of 2D-based counter electrodes applied in solar-assisted devices. Coord. Chem. Rev. 324, 54-81 (2016).

8. Hu Yun Hang, Wang Hui \& Hu Bo. Thinnest Two-Dimensional Nanomaterial-Graphene for Solar Energy. ChemSusChem 3, 782-796 (2010).

9. Sun, Z., Ma, T., Tao, H., Fan, Q. \& Han, B. Fundamentals and Challenges of Electrochemical CO2 Reduction Using Two-Dimensional Materials. CHEM 3, 560-587 (2017).

10. Kumar, A. \& Xu, Q. Two-Dimensional Layered Materials as Catalyst Supports. CHEMNANOMAT 4, 28-40 (2018).

11. Deng, D. et al. Catalysis with two-dimensional materials and their heterostructures. Nat. Nanotechnol. 11, 218-230 (2016). 
12. Varghese, S., Varghese, S., Swaminathan, S., Singh, K. \& Mittal, V. Two-Dimensional Materials for Sensing: Graphene and Beyond. Electronics 4, 651-687 (2015).

13. Barzegar, M. \& Tudu, B. Two-Dimensional Materials for Gas Sensors: From First Discovery to Future Possibilities. Surf. Innov. 0, 1-79 (0).

14. Aghigh, A. et al. Recent advances in utilization of graphene for filtration and desalination of water: A review. DESALINATION 365, 389-397 (2015).

15. Pumera, M. \& Loo, A. H. Layered transition-metal dichalcogenides (MoS2 and WS2) for sensing and biosensing. TrAC Trends Anal. Chem. 61, 49-53 (2014).

16. Ajayan, P., Kim, P. \& Banerjee, K. Two-dimensional van der Waals materials. Phys. Today 69, 38-44 (2016).

17. Geim, A. K. \& Grigorieva, I. V. Van der Waals heterostructures. Nature 499, 419-425 (2013).

18. Novoselov, K. S., Mishchenko, A., Carvalho, A. \& Castro Neto, A. H. 2D materials and van der Waals heterostructures. Science 353, (2016).

19. Lim, H., Yoon, S. I., Kim, G., Jang, A.-R. \& Shin, H. S. Stacking of Two-Dimensional Materials in Lateral and Vertical Directions. Chem. Mater. 26, 4891-4903 (2014).

20. Backes, C. et al. Guidelines for Exfoliation, Characterization and Processing of Layered Materials Produced by Liquid Exfoliation. Chem. Mater. 29, 243-255 (2017).

21. Bonaccorso, F. et al. Production and processing of graphene and $2 \mathrm{~d}$ crystals. Mater. Today 15, 564-589 (2012).

22. Kanarik, K. J. et al. Overview of atomic layer etching in the semiconductor industry. J. Vac. Sci. Technol. Vac. Surf. Films 33, 020802 (2015).

23. Lin, Z. et al. 2D materials advances: from large scale synthesis and controlled heterostructures to improved characterization techniques, defects and applications. 2D Mater. 3, (2016).

24. Mannix, A. J., Kiraly, B., Hersam, M. C. \& Guisinger, N. P. Synthesis and chemistry of elemental 2D materials. Nat. Rev. Chem. 1, 0014 (2017). 
25. Mattevi, C., Kim, H. \& Chhowalla, M. A review of chemical vapour deposition of graphene on copper. J. Mater. Chem. 21, 3324-3334 (2011).

26. Li, X. et al. Large-Area Synthesis of High-Quality and Uniform Graphene Films on Copper Foils. Science 324, 1312 (2009).

27. Leskelä, M. \& Ritala, M. Atomic Layer Deposition Chemistry: Recent Developments and Future Challenges. Angew. Chem. Int. Ed. 42, 5548-5554 (2003).

28. George, S. M. Atomic Layer Deposition: An Overview. Chem. Rev. 110, 111-131 (2010).

29. Liu, H. Recent Progress in Atomic Layer Deposition of Multifunctional Oxides and TwoDimensional Transition Metal Dichalcogenides. J. Mol. Eng. Mater. 1640010 (2017). doi:10.1142/S2251237316400104

30. Puurunen, R. L. Surface chemistry of atomic layer deposition: A case study for the trimethylaluminum/water process. J. Appl. Phys. 97, 121301 (2005).

31. Miikkulainen, V., Leskelä, M., Ritala, M. \& Puurunen, R. L. Crystallinity of inorganic films grown by atomic layer deposition: Overview and general trends. J. Appl. Phys. 113, 021301 (2013).

32. Dimiev, A. et al. Layer-by-Layer Removal of Graphene for Device Patterning. Science 331, 1168$1172(2011)$.

33. Dasgupta, N. P., Meng, X., Elam, J. W. \& Martinson, A. B. F. Atomic Layer Deposition of Metal Sulfide Materials. Acc. Chem. Res. 48, 341-348 (2015).

34. Bosi, M. Growth and synthesis of mono and few-layers transition metal dichalcogenides by vapour techniques: a review. RSC Adv 5, 75500-75518 (2015).

35. Song, J.-G., Park, K., Park, J. \& Kim, H. Vapor Deposition Techniques for Synthesis of TwoDimensional Transition Metal Dichalcogenides. Appl. Microsc. 45, 119-125 (2015).

36. Van Bui, H., Grillo, F. \& van Ommen, J. R. Atomic and molecular layer deposition: off the beaten track. Chem Commun 53, 45-71 (2017). 
37. Zhuiykov, S., Kawaguchi, T., Hai, Z., Karbalaei Akbari, M. \& Heynderickx, P. M. Interfacial engineering of two-dimensional nano-structured materials by atomic layer deposition. Appl. Surf. Sci. 392, 231-243 (2017).

38. Ataca, C., Şahin, H. \& Ciraci, S. Stable, Single-Layer MX2 Transition-Metal Oxides and Dichalcogenides in a Honeycomb-Like Structure. J. Phys. Chem. C 116, 8983-8999 (2012).

39. Chhowalla, M. et al. The chemistry of two-dimensional layered transition metal dichalcogenide nanosheets. Nat. Chem. 5, 263-275 (2013).

40. Tan, C. et al. Recent Advances in Ultrathin Two-Dimensional Nanomaterials. Chem. Rev. 117, 6225-6331 (2017).

41. Zhuang, X., Mai, Y., Wu, D., Zhang, F. \& Feng, X. Two-Dimensional Soft Nanomaterials: A Fascinating World of Materials. Adv. Mater. 27, 403-427 (2015).

42. Novoselov, K. S. et al. A roadmap for graphene. nature 490, 192-200 (2012).

43. Raccichini, R., Varzi, A., Passerini, S. \& Scrosati, B. The role of graphene for electrochemical energy storage. Nat. Mater. 14, 271 (2015).

44. Zhang, Y. I., Zhang, L. \& Zhou, C. Review of chemical vapor deposition of graphene and related applications. Acc. Chem. Res. 46, 2329-2339 (2013).

45. Zhang, Y. et al. Low-temperature remote plasma-enhanced atomic layer deposition of graphene and characterization of its atomic-level structure. J. Mater. Chem. C 2, 7570 (2014).

46. Kim, Y. Y., Lim, W. S., Park, J. B. \& Yeom, G. Y. Layer by layer etching of the highly oriented pyrolythic graphite by using atomic layer etching. J. Electrochem. Soc. 158, D710-D714 (2011).

47. Lim, W. S. et al. Atomic layer etching of graphene for full graphene device fabrication. Carbon 50, 429-435 (2012).

48. Fredriksson, H., Chakarov, D. \& Kasemo, B. Patterning of highly oriented pyrolytic graphite and glassy carbon surfaces by nanolithography and oxygen plasma etching. Carbon 47, 1335-1342 (2009). 
49. Lemme, M. C. et al. Etching of Graphene Devices with a Helium Ion Beam. ACS Nano 3, 26742676 (2009).

50. Kim, K. S. et al. Atomic layer etching of graphene through controlled ion beam for graphenebased electronics. Sci. Rep. 7, 2462 (2017).

51. Chubarov, M. et al. Polytype Pure $\mathrm{sp}^{2}$-BN Thin Films As Dictated by the Substrate Crystal Structure. Chem. Mater. 27, 1640-1645 (2015).

52. Han, J., Lee, J.-Y., Kwon, H. \& Yeo, J.-S. Synthesis of wafer-scale hexagonal boron nitride monolayers free of aminoborane nanoparticles by chemical vapor deposition. Nanotechnology 25, 145604 (2014).

53. Haider, A., Ozgit-Akgun, C., Goldenberg, E., Okyay, A. K. \& Biyikli, N. Low-Temperature Deposition of Hexagonal Boron Nitride via Sequential Injection of Triethylboron and $\mathrm{N}_{2} / \mathrm{H}_{2}$ Plasma. J. Am. Ceram. Soc. 97, 4052-4059 (2014).

54. Gannett, W. et al. Boron nitride substrates for high mobility chemical vapor deposited graphene. Appl. Phys. Lett. 98, 242105 (2011).

55. Dean, C. R. et al. Boron nitride substrates for high-quality graphene electronics. Nat. Nanotechnol. 5, 722-726 (2010).

56. Britnell, L. et al. Field-Effect Tunneling Transistor Based on Vertical Graphene Heterostructures. Science 335, 947-950 (2012).

57. Coleman, J. N. et al. Two-Dimensional Nanosheets Produced by Liquid Exfoliation of Layered Materials. Science 331, 568-571 (2011).

58. M?rlid, B., Ottosson, M., Pettersson, U., Larsson, K. \& Carlsson, J.-O. Atomic layer deposition of BN thin films. Thin Solid Films 402, 167-171 (2002).

59. Ferguson, J. ., Weimer, A. . \& George, S. . Atomic layer deposition of boron nitride using sequential exposures of $\mathrm{BCl} 3$ and NH3. Thin Solid Films 413, 16-25 (2002).

60. Kilbury, O. J. et al. Atomic layer deposition of solid lubricating coatings on particles. Powder Technol. 221, 26-35 (2012). 
61. Driver, M. S. et al. Atomic Layer Epitaxy of h-BN(0001) Multilayers on Co(0001) and Molecular Beam Epitaxy Growth of Graphene on h-BN(0001)/Co(0001). Langmuir 32, 2601-2607 (2016).

62. Weber, M. et al. Boron Nitride Nanoporous Membranes with High Surface Charge by Atomic Layer Deposition. ACS Appl. Mater. Interfaces 9, 16669-16678 (2017).

63. Consiglio, S. et al. Comparison of $\mathrm{B}_{2} \mathrm{O}_{3}$ and $\mathrm{BN}$ deposited by atomic layer deposition for forming ultrashallow dopant regions by solid state diffusion. J. Vac. Sci. Technol. Vac. Surf. Films 34, $01 \mathrm{~A} 102$ (2016).

64. Controlled epitaxial boron nitride growth for graphene based transistors.

65. Bjelkevig, C. et al. Electronic structure of a graphene/hexagonal-BN heterostructure grown on $\mathrm{Ru}(0001)$ by chemical vapor deposition and atomic layer deposition: extrinsically doped graphene. J. Phys. Condens. Matter 22, 302002 (2010).

66. Hemmi, A. et al. High quality single atomic layer deposition of hexagonal boron nitride on single crystalline Rh(111) four-inch wafers. Rev. Sci. Instrum. 85, 035101 (2014).

67. Park, H. et al. Large-scale synthesis of uniform hexagonal boron nitride films by plasmaenhanced atomic layer deposition. Sci. Rep. 7, 40091 (2017).

68. Olander, J., Ottosson, L. M., Heszler, P., Carlsson, J.-O. \& Larsson, K. M. E. Laser-Assisted Atomic Layer Deposition of Boron Nitride Thin Films. Chem. Vap. Depos. 11, 330-337 (2005).

69. Haider, A., Kizir, S., Ozgit-Akgun, C., Okyay, A. K. \& Biyikli, N. Low-temperature sequential pulsed chemical vapor deposition of ternary $B_{x} G_{1-x} N$ and $B_{x} \ln _{1-x} N$ thin film alloys. J. Vac. Sci. Technol. Vac. Surf. Films 34, $01 \mathrm{~A} 123$ (2016).

70. Chan, K. K. et al. Low temperature spacer for advanced semiconductor devices. (2016).

71. Snure, M., Paduano, Q., Hamilton, M., Shoaf, J. \& Mann, J. M. Optical characterization of nanocrystalline boron nitride thin films grown by atomic layer deposition. Thin Solid Films 571, 51-55 (2014).

72. Weimer, M. A., Weimer, A. W. \& Park, W. Theory of conduction in ultrafast metal-insulator varistors. J. Appl. Phys. 104, 114516 (2008). 
73. Hao, W., Marichy, C., Journet, C. \& Brioude, A. A Novel Two-Step Ammonia-Free Atomic Layer Deposition Approach for Boron Nitride. ChemNanoMat 3, 656-663 (2017).

74. Ismach, A. et al. Toward the Controlled Synthesis of Hexagonal Boron Nitride Films. ACS Nano 6, 6378-6385 (2012).

75. Kovalgin, A. Y. et al. Hot-Wire Assisted ALD: A Study Powered by In Situ Spectroscopic Ellipsometry. Adv. Mater. Interfaces 4, 1700058 (2017).

76. Sprenger, J. K. et al. Electron-Enhanced Atomic Layer Deposition of Boron Nitride Thin Films at Room Temperature and $100{ }^{\circ} \mathrm{C}$. J. Phys. Chem. C 122, 9455-9464 (2018).

77. Olander, J. \& Larsson, K. Cubic boron nitride growth from NH3 and BBr3 precursors: a theoretical study. Diam. Relat. Mater. 11, 1286-1289 (2002).

78. Weber, M. et al. Mechanical properties of boron nitride thin films prepared by atomic layer deposition. CrystEngComm 19, 6089-6094 (2017).

79. Beatty, J. et al. Atomic layer-by-layer deposition of h-BN (0001) on cobalt: a building block for spintronics and graphene electronics. Mater. Res. Express 1, 046410 (2014).

80. Kelber, J. Controlled epitaxial boron nitride growth for graphene based transistors. (2015).

81. Jones, J. et al. Atomic layer deposition of h-BN (0001) on RuO2 (110)/Ru (0001). J. Vac. Sci. Technol. Vac. Surf. Films 35, $01 \mathrm{~B} 139$ (2017).

82. Wolf, S., Edmonds, M., Kummel, A. C., Nemani, S. \& Yieh, E. LOW-TEMPERATURE ATOMIC LAYER DEPOSITION OF BORON NITRIDE AND BN STRUCTURES.

83. Wolf, S. et al. Low-temperature amorphous boron nitride on Si $0.7 \mathrm{Ge} 0.3(001)$, Cu, and HOPG from sequential exposures of N $2 \mathrm{H} 4$ and BCl 3. Appl. Surf. Sci. 439, 689-696 (2018).

84. Haider, A. et al. Fabrication of AIN/BN bishell hollow nanofibers by electrospinning and atomic layer deposition. APL Mater. 2, 096109 (2014).

85. Hao, W., Marichy, C. \& Brioude, A. Promising properties of ALD boron nitride nanotube mats for water purification. Environ. Sci. Nano 4, 2311-2320 (2017).

86. Zhuiykov, S. Nanostructured Semiconductors. (Elsevier Science, 2018). 
87. Suntola T. \& Antson J. METHOD FOR PRODUCING COMPOUND THIN FILMS.

88. Kim, S. B., Sinsermsuksakul, P., Hock, A. S., Pike, R. D. \& Gordon, R. G. Synthesis of NHeterocyclic Stannylene (Sn(II)) and Germylene (Ge(II)) and a Sn(II) Amidinate and Their Application as Precursors for Atomic Layer Deposition. Chem. Mater. 26, 3065-3073 (2014).

89. Riha, S. C. et al. Atomic Layer Deposition of MnS: Phase Control and Electrochemical Applications. ACS Appl. Mater. Interfaces 8, 2774-2780 (2016).

90. Meng, X. et al. Atomic Layer Deposition of Gallium Sulfide Films Using Hexakis(dimethylamido)digallium and Hydrogen Sulfide. Chem. Mater. 26, 1029-1039 (2014).

91. Mahuli, N. \& Sarkar, S. K. Atomic layer deposition of NiS and its application as cathode material in dye sensitized solar cell. J. Vac. Sci. Technol. Vac. Surf. Films 34, $01 \mathrm{~A} 142$ (2016).

92. Shao, Y., Guo, Z., Li, H., Su, Y. \& Wang, X. Atomic Layer Deposition of Iron Sulfide and Its Application as a Catalyst in the Hydrogenation of Azobenzenes. Angew. Chem. Int. Ed. 56, $3226-3231$ (2017).

93. Browning, R., Kuperman, N., Moon, B. \& Solanki, R. Atomic Layer Growth of InSe and Sb2Se3 Layered Semiconductors and Their Heterostructure. Electronics 6, 27 (2017).

94. Lin, T. et al. Controlled Layer-by-Layer Etching of $\mathrm{MoS}_{2}$. ACS Appl. Mater. Interfaces 7, 1589215897 (2015).

95. Kim, Y. et al. Self-Limiting Layer Synthesis of Transition Metal Dichalcogenides. Sci. Rep. 6, (2016).

96. Park, K. et al. Uniform, large-area self-limiting layer synthesis of tungsten diselenide. 2D Mater. 3, 014004 (2016).

97. Wang, H. et al. Electrochemical tuning of vertically aligned MoS2 nanofilms and its application in improving hydrogen evolution reaction. Proc. Natl. Acad. Sci. 110, 19701-19706 (2013).

98. Martella, C. et al. Engineering the Growth of $\mathrm{MoS}_{2}$ via Atomic Layer Deposition of Molybdenum Oxide Film Precursor. Adv. Electron. Mater. 2, 1600330 (2016). 
99. Keller, B. D. et al. Process Control of Atomic Layer Deposition Molybdenum Oxide Nucleation and Sulfidation to Large-Area $\mathrm{MoS}_{2}$ Monolayers. Chem. Mater. 29, 2024-2032 (2017).

100. Tan, L. K. et al. Atomic layer deposition of a $\mathrm{MoS}_{2}$ film. Nanoscale 6, 10584-10588 (2014).

101. Browning, R. et al. Atomic layer deposition of $\mathrm{MoS}_{2}$ thin films. Mater. Res. Express 2, 035006 (2015).

102. Liu, L., Huang, Y., Sha, J. \& Chen, Y. Layer-controlled precise fabrication of ultrathin MoS $_{2}$ films by atomic layer deposition. Nanotechnology 28, 195605 (2017).

103. Huang, Y., Liu, L., Zhao, W. \& Chen, Y. Preparation and characterization of molybdenum disulfide films obtained by one-step atomic layer deposition method. Thin Solid Films 624, 101105 (2017).

104. Valdivia, A., Tweet, D. J. \& Conley, J. F. Atomic layer deposition of two dimensional $\mathrm{MoS}_{2}$ on 150 mm substrates. J. Vac. Sci. Technol. Vac. Surf. Films 34, 021515 (2016).

105. Nandi, D. K., Sen, U. K., Choudhury, D., Mitra, S. \& Sarkar, S. K. Atomic Layer Deposited MoS2 as a Carbon and Binder Free Anode in Li-ion Battery. Electrochimica Acta 146, 706-713 (2014).

106. Pyeon, J. J. et al. Wafer-scale growth of $\mathrm{MoS}_{2}$ thin films by atomic layer deposition. Nanoscale 8, 10792-10798 (2016).

107. Xiong, D. et al. Atomic-layer-deposited ultrafine $\mathrm{MoS}_{2}$ nanocrystals on cobalt foam for efficient and stable electrochemical oxygen evolution. Nanoscale 9, 2711-2717 (2017).

108. Jang, Y., Yeo, S., Lee, H.-B.-R., Kim, H. \& Kim, S.-H. Wafer-scale, conformal and direct growth of MoS 2 thin films by atomic layer deposition. Appl. Surf. Sci. 365, 160-165 (2016).

109. Oh, S., Kim, J. B., Song, J. T., Oh, J. \& Kim, S.-H. Atomic layer deposited molybdenum disulfide on Si photocathodes for highly efficient photoelectrochemical water reduction reaction. J Mater Chem A 5, 3304-3310 (2017).

110. Jin, Z., Shin, S., Kwon, D. H., Han, S.-J. \& Min, Y.-S. Novel chemical route for atomic layer deposition of $\mathrm{MoS}_{2}$ thin film on $\mathrm{SiO}_{2}$ /Si substrate. Nanoscale 6, 14453-14458 (2014). 
111. Kwon, D. H., Jin, Z., Shin, S., Lee, W.-S. \& Min, Y.-S. A comprehensive study on atomic layer deposition of molybdenum sulfide for electrochemical hydrogen evolution. Nanoscale $\mathbf{8 ,} 7180$ 7188 (2016).

112. Shin, S., Jin, Z., Kwon, D. H., Bose, R. \& Min, Y.-S. High Turnover Frequency of Hydrogen Evolution Reaction on Amorphous $\mathrm{MoS}_{2}$ Thin Film Directly Grown by Atomic Layer Deposition. Langmuir 31, 1196-1202 (2015).

113. Mattinen, M. et al. Atomic Layer Deposition of Crystalline $\mathrm{MoS}_{2}$ Thin Films: New Molybdenum Precursor for Low-Temperature Film Growth. Adv. Mater. Interfaces 1700123 (2017). doi:10.1002/admi.201700123

114. Jurca, T. et al. Low-Temperature Atomic Layer Deposition of MoS $_{2}$ Films. Angew. Chem. 129, 5073-5077 (2017).

115. Cadot, S. et al. A novel 2-step ALD route to ultra-thin $\mathrm{MoS}_{2}$ films on $\mathrm{SiO}_{2}$ through a surface organometallic intermediate. Nanoscale 9, 538-546 (2017).

116. Kim, K. S. et al. Atomic Layer Etching Mechanism of $\mathrm{MoS}_{2}$ for Nanodevices. ACS Appl. Mater. Interfaces 9, 11967-11976 (2017).

117. Mercado, E., Goodyear, A., Moffat, J., Cooke, M. \& Sundaram, R. S. A Raman metrology approach to quality control of 2D MoS 2 film fabrication. J. Phys. Appl. Phys. 50, 184005 (2017).

118. Zhu, H. et al. Remote Plasma Oxidation and Atomic Layer Etching of MoS ${ }_{2}$. ACS Appl. Mater. Interfaces 8, 19119-19126 (2016).

119. Choi, S. Y. et al. Effect of Nb Doping on Chemical Sensing Performance of Two-Dimensional Layered MoSe ${ }_{2}$. ACS Appl. Mater. Interfaces 9, 3817-3823 (2017).

120. Scharf, T. W., Prasad, S. V., Mayer, T. M., Goeke, R. S. \& Dugger, M. T. Atomic layer deposition of tungsten disulphide solid lubricant thin films. J. Mater. Res. 19, 3443-3446 (2004).

121. Scharf, T. et al. Growth, structure, and tribological behavior of atomic layer-deposited tungsten disulphide solid lubricant coatings with applications to MEMS. Acta Mater. 54, 4731-4743 (2006). 
122. Scharf, T. W., Diercks, D. R., Gorman, B. P., Prasad, S. V. \& Dugger, M. T. Atomic Layer Deposition of Tungsten Disulphide Solid Lubricant Nanocomposite Coatings on Rolling Element Bearings. Tribol. Trans. 52, 284-292 (2009).

123. Delabie, A. et al. Low temperature deposition of $2 \mathrm{D} \mathrm{WS}{ }_{2}$ layers from $\mathrm{WF}_{6}$ and $\mathrm{H}_{2} \mathrm{~S}$ precursors: impact of reducing agents. Chem Commun 51, 15692-15695 (2015).

124. Groven, B. et al. Plasma-Enhanced Atomic Layer Deposition of Two-Dimensional WS ${ }_{2}$ from WF 6, $\mathrm{H}_{2}$ Plasma, and $\mathrm{H}_{2}$ S. Chem. Mater. 29, 2927-2938 (2017).

125. Browning, R., Plachinda, P., Padigi, P., Solanki, R. \& Rouvimov, S. Growth of multiple WS ${ }_{2} / \mathrm{SnS}$ layered semiconductor heterojunctions. Nanoscale 8, 2143-2148 (2016).

126. Sun, Y., Chai, Z., Lu, X. \& He, D. A direct atomic layer deposition method for growth of ultra-thin lubricant tungsten disulfide films. Sci. China Technol. Sci. 60, 51-57 (2017).

127. Nandi, D. K., Sen, U. K., Dhara, A., Mitra, S. \& Sarkar, S. K. Intercalation based tungsten disulfide (WS ${ }_{2}$ ) Li-ion battery anode grown by atomic layer deposition. RSC Adv 6, 38024-38032 (2016).

128. Song, J.-G. et al. Layer-Controlled, Wafer-Scale, and Conformal Synthesis of Tungsten Disulfide Nanosheets Using Atomic Layer Deposition. ACS Nano 7, 11333-11340 (2013).

129. Ko, K. Y. et al. Improvement of Gas-Sensing Performance of Large-Area Tungsten Disulfide Nanosheets by Surface Functionalization. ACS Nano 10, 9287-9296 (2016).

130. Li, N., Feng, L., Su, J., Zeng, W. \& Liu, Z. Optical and electrical properties of Al:WS ${ }_{2}$ films prepared by atomic layer deposition and vulcanization. RSC Adv 6, 64879-64884 (2016).

131. Song, J.-G. et al. Controllable synthesis of molybdenum tungsten disulfide alloy for vertically composition-controlled multilayer. Nat. Commun. 6, 7817 (2015).

132. Browning, R., Kuperman, N., Solanki, R., Kanzyuba, V. \& Rouvimov, S. Large area growth of layered WSe ${ }_{2}$ films. Semicond. Sci. Technol. 31, 095002 (2016).

133. Bilousov, O. V. et al. Atomic Layer Deposition of Cubic and Orthorhombic Phase Tin Monosulfide. Chem. Mater. 29, 2969-2978 (2017). 
134. Kim, J. Y. \& George, S. M. Tin Monosulfide Thin Films Grown by Atomic Layer Deposition Using Tin 2,4-Pentanedionate and Hydrogen Sulfide. J. Phys. Chem. C 114, 17597-17603 (2010).

135. Sinsermsuksakul, P. et al. Antimony-Doped Tin(II) Sulfide Thin Films. Chem. Mater. 24, 45564562 (2012).

136. Sinsermsuksakul, P. et al. Enhancing the efficiency of SnS solar cells via band-offset engineering with a zinc oxysulfide buffer layer. Appl. Phys. Lett. 102, 053901 (2013).

137. Sinsermsuksakul, P., Heo, J., Noh, W., Hock, A. S. \& Gordon, R. G. Atomic Layer Deposition of Tin Monosulfide Thin Films. Adv. Energy Mater. 1, 1116-1125 (2011).

138. Sinsermsuksakul, P. et al. Overcoming Efficiency Limitations of SnS-Based Solar Cells. Adv. Energy Mater. 4, 1400496 (2014).

139. Sun, L. et al. Band alignment of $\mathrm{SnS} / \mathrm{Zn}(\mathrm{O}, \mathrm{S})$ heterojunctions in SnS thin film solar cells. Appl. Phys. Lett. 103, 181904 (2013).

140. Ham, G. et al. Tuning the Electronic Structure of Tin Sulfides Grown by Atomic Layer Deposition. ACS Appl. Mater. Interfaces 5, 8889-8896 (2013).

141. Ham, G. et al. Engineering the crystallinity of tin disulfide deposited at low temperatures. RSC Adv 6, 54069-54075 (2016).

142. Jang, B., Yeo, S., Kim, H., Shin, B. \& Kim, S.-H. Fabrication of single-phase SnS film by $\mathrm{H}_{2}$ annealing of amorphous SnS $\times$ prepared by atomic layer deposition. J. Vac. Sci. Technol. Vac. Surf. Films 35, 031506 (2017).

143. Lee, J. et al. Improved electrical properties of atomic layer deposited tin disulfide at low temperatures using ZrO2 layer. AIP Adv. 7, 025311 (2017).

144. Mattinen Miika et al. Low-Temperature Wafer-Scale Deposition of Continuous 2D SnS2 Films. Small 0, 1800547 (2018).

145. Mahuli, N. \& Sarkar, S. K. Atomic layer deposition of titanium sulfide and its application in extremely thin absorber solar cells. J. Vac. Sci. Technol. Vac. Surf. Films 33, 01A150 (2015). 
146. Pore, V., Ritala, M. \& Leskelä, M. Atomic Layer Deposition of Titanium Disulfide Thin Films.

Chem. Vap. Depos. 13, 163-168 (2007).

147. Meng, X. et al. Gallium Sulfide-Single-Walled Carbon Nanotube Composites: High-Performance Anodes for Lithium-Ion Batteries. Adv. Funct. Mater. 24, 5435-5442 (2014).

148. Hatanpää, T., Pore, V., Ritala, M. \& Leskelä, M. Alkylsilyl Compounds of Selenium and Tellurium: New Precursors for ALD. in 609-616 (ECS, 2009). doi:10.1149/1.3207647

149. Pore, V., Hatanpää, T., Ritala, M. \& Leskelä, M. Atomic Layer Deposition of Metal Tellurides and Selenides Using Alkylsilyl Compounds of Tellurium and Selenium. J. Am. Chem. Soc. 131, 34783480 (2009).

150. Bae, C. et al. Thermopower engineering of $\mathrm{Bi}_{2} \mathrm{Te}_{3}$ without alloying: the interplay between nanostructuring and defect activation. Semicond. Sci. Technol. 29, 064003 (2014).

151. Sarnet, T. et al. Atomic Layer Deposition and Characterization of $\mathrm{Bi}_{2} \mathrm{Te}_{3}$ Thin Films. J. Phys. Chem. A 119, 2298-2306 (2015).

152. Rusek, M., Komossa, T., Bendt, G. \& Schulz, S. Bismuth amides as promising ALD precursors for Bi 2 Te 3 films. J. Cryst. Growth 470, 128-134 (2017).

153. Sarnet, T. et al. (Et $\left.{ }_{3} \mathrm{Si}\right)_{2}$ Se as a precursor for atomic layer deposition: growth analysis of thermoelectric $\mathrm{Bi}_{2} \mathrm{Se}_{3}$. J Mater Chem C 3, 4820-4828 (2015).

154. Mahuli, N., Saha, D. \& Sarkar, S. K. Atomic Layer Deposition of p-Type $\mathrm{Bi}_{2} \mathrm{~S}_{3}$. J. Phys. Chem. C 121, 8136-8144 (2017).

155. Marichy, C. \& Pinna, N. Carbon-nanostructures coated/decorated by atomic layer deposition: Growth and applications. Chem. Vap. Depos. At. Layer Depos. Precursor Des. Appl. 257, 32323253 (2013).

156. Zheng, L. et al. Direct growth of $\mathrm{Sb}_{2} \mathrm{Te}_{3}$ on graphene by atomic layer deposition. RSC Adv 5, 40007-40011 (2015).

157. Nminibapiel, D. et al. Microstructure Analysis of ALD Bi2Te3/Sb2Te3 Thermoelectric Nanolaminates. ECS Trans. 58, 59-66 (2013). 
158. Zhang, K., Nminibapiel, D., Tangirala, M., Baumgart, H. \& Kochergin, V. Fabrication of Sb2Te3 and Bi2Te3 Multilayer Composite Films by Atomic Layer Deposition. ECS Trans. 50, 3-9 (2013).

159. Nminibapiel, D. et al. Growth of Nanolaminates of Thermoelectric Bi2Te3/Sb2Te3 by Atomic Layer Deposition. ECS J. Solid State Sci. Technol. 3, P95-P100 (2014).

160. Liu, H. F. et al. Atomic layer deposition of crystalline $\mathrm{Bi}_{2} \mathrm{O}_{3}$ thin films and their conversion into $\mathrm{Bi}_{2} \mathrm{~S}_{3}$ by thermal vapor sulfurization. RSC Adv 4, 58724-58731 (2014).

161. Marichy Catherine, Bechelany Mikhael \& Pinna Nicola. Atomic Layer Deposition of Nanostructured Materials for Energy and Environmental Applications. Adv. Mater. 24, 10171032 (2012).

162. Singh, T., Lehnen, T., Leuning, T. \& Mathur, S. Atomic layer deposition grown $M O_{x}$ thin films for solar water splitting: Prospects and challenges. J. Vac. Sci. Technol. Vac. Surf. Films 33, 010801 (2015).

163. Liu, R. et al. Water Splitting by Tungsten Oxide Prepared by Atomic Layer Deposition and Decorated with an Oxygen-Evolving Catalyst. Angew. Chem. Int. Ed. 50, 499-502 (2011).

164. Gesheva, K. et al. Technologies for deposition of transition metal oxide thin films: application as functional layers in 'Smart windows' and photocatalytic systems. J. Phys. Conf. Ser. 682, 012011 (2016).

165. Juholin, P. et al. Comparison of ALD coated nanofiltration membranes to unmodified commercial membranes in mine wastewater treatment. Sep. Purif. Technol. 192, 69-77 (2018).

166. Huong Le, T. X. et al. Design of a novel fuel cell-Fenton system: a smart approach to zero energy depollution. J. Mater. Chem. A 4, 17686-17693 (2016).

167. Bivour, M., Macco, B., Temmler, J., Kessels, W. M. M. (Erwin) \& Hermle, M. Atomic Layer Deposited Molybdenum Oxide for the Hole-selective Contact of Silicon Solar Cells. Energy Procedia 92, 443-449 (2016).

168. Vos, M. F. J. Atomic layer deposition of molybdenum oxide. (2015). 
169. Macco, B., Vos, M. F. J., Thissen, N. F. W., Bol, A. A. \& Kessels, W. M. M. Low-temperature atomic layer deposition of $\mathrm{MoO}{ }_{x}$ for silicon heterojunction solar cells: Low-temperature atomic layer deposition of $\mathrm{MoO}_{x}$ for silicon heterojunction solar cells. Phys. Status Solidi RRL Rapid Res. Lett. 9, 393-396 (2015).

170. Ziegler, J. et al. Plasma-enhanced atomic-layer-deposited MoO x emitters for silicon heterojunction solar cells. Appl. Phys. A 120, 811-816 (2015).

171. Tseng, Y.-C., Mane, A. U., Elam, J. W. \& Darling, S. B. Ultrathin molybdenum oxide anode buffer layer for organic photovoltaic cells formed using atomic layer deposition. Sol. Energy Mater. Sol. Cells 99, 235-239 (2012).

172. Wang, F., Qiao, X., Xiong, T. \& Ma, D. The role of molybdenum oxide as anode interfacial modification in the improvement of efficiency and stability in organic light-emitting diodes. Org. Electron. 9, 985-993 (2008).

173. Besenhard, J. O., Heydecke, J., Wudy, E., Fritz, H. P. \& Foag, W. Characteristics of molybdenum oxide and chromium oxide cathodes in primary and secondary organic electrolyte lithium batteries. Part II. Transport properties. Solid State Ion. 8, 61-71 (1983).

174. Chary, K. Structure and catalytic properties of molybdenum oxide catalysts supported on zirconia. J. Catal. 226, 283-291 (2004).

175. El-Sharkawy, E. A., Khder, A. S. \& Ahmed, A. I. Structural characterization and catalytic activity of molybdenum oxide supported zirconia catalysts. Microporous Mesoporous Mater. 102, 128 137 (2007).

176. Lin, S.-Y., Wang, C.-M., Kao, K.-S., Chen, Y.-C. \& Liu, C.-C. Electrochromic properties of MoO3 thin films derived by a sol-gel process. J. Sol-Gel Sci. Technol. 53, 51-58 (2010).

177. Ivanova, T., Gesheva, K. A., Popkirov, G., Ganchev, M. \& Tzvetkova, E. Electrochromic properties of atmospheric CVD MoO3 and MoO3-WO3 films and their application in electrochromic devices. Mater. Sci. Eng. B 119, 232-239 (2005). 
178. Zollfrank, C., Gutbrod, K., Wechsler, P. \& Guggenbichler, J. P. Antimicrobial activity of transition metal acid MoO3 prevents microbial growth on material surfaces. Mater. Sci. Eng. C 32, 47-54 (2012).

179. Vos, M. F. J., Macco, B., Thissen, N. F. W., Bol, A. A. \& Kessels, W. M. M. (Erwin). Atomic layer deposition of molybdenum oxide from $\left(\mathrm{N}^{t} \mathrm{Bu}\right)_{2}\left(\mathrm{NMe}_{2}\right)_{2} \mathrm{Mo}$ and $\mathrm{O}_{2}$ plasma. J. Vac. Sci. Technol. Vac. Surf. Films 34, $01 \mathrm{~A} 103$ (2016).

180. Bertuch, A., Sundaram, G., Saly, M., Moser, D. \& Kanjolia, R. Atomic layer deposition of molybdenum oxide using bis(tert-butylimido)bis(dimethylamido) molybdenum. J. Vac. Sci. Technol. Vac. Surf. Films 32, 01A119 (2014).

181. Nandi, D. K. \& Sarkar, S. K. Atomic Layer Deposition of Molybdenum Oxide for Solar Cell Application. Appl. Mech. Mater. 492, 375-379 (2014).

182. Diskus, M., Nilsen, O. \& Fjellvåg, H. Growth of thin films of molybdenum oxide by atomic layer deposition. J Mater Chem 21, 705-710 (2011).

183. Diskus, M. et al. Combination of characterization techniques for atomic layer deposition $\mathrm{MoO}_{3}$ coatings: From the amorphous to the orthorhombic $\alpha-\mathrm{MoO}_{3}$ crystalline phase. J. Vac. Sci. Technol. Vac. Surf. Films 30, 01A107 (2012).

184. Diskus, M., Balasundaram, M., Nilsen, O. \& Fjellvåg, H. Influence of precursors chemistry on ALD growth of cobalt-molybdenum oxide films. Dalton Trans. 41, 2439 (2012).

185. Jurca, T. et al. Second-generation hexavalent molybdenum oxo-amidinate precursors for atomic layer deposition. Dalton Trans 46, 1172-1178 (2017).

186. Drake, T. L. \& Stair, P. C. Vapor deposition of molybdenum oxide using bis(ethylbenzene) molybdenum and water. J. Vac. Sci. Technol. Vac. Surf. Films 34, 051403 (2016).

187. Nanayakkara, C. E. et al. Role of Initial Precursor Chemisorption on Incubation Delay for Molybdenum Oxide Atomic Layer Deposition. Chem. Mater. 28, 8591-8597 (2016). 
188. Seghete, D., Rayner, G. B., Cavanagh, A. S., Anderson, V. R. \& George, S. M. Molybdenum Atomic Layer Deposition Using $\mathrm{MoF}_{6}$ and $\mathrm{Si}_{2} \mathrm{H}_{6}$ as the Reactants. Chem. Mater. 23, 1668-1678 (2011).

189. Granqvist, C. G. Electrochromic tungsten oxide films: Review of progress 1993-1998. Sol. Energy Mater. Sol. Cells 60, 201-262 (2000).

190. Lee, S.-H. et al. Crystalline WO3 Nanoparticles for Highly Improved Electrochromic Applications. Adv. Mater. 18, 763-766 (2006).

191. Yoon, S., Woo, S.-G., Jung, K.-N. \& Song, H. Conductive surface modification of cauliflower-like WO3 and its electrochemical properties for lithium-ion batteries. J. Alloys Compd. 613, 187-192 (2014).

192. Zhuiykov, S. \& Kats, E. Atomically thin two-dimensional materials for functional electrodes of electrochemical devices. Ionics 19, 825-865 (2013).

193. Ham, D. J., Phuruangrat, A., Thongtem, S. \& Lee, J. S. Hydrothermal synthesis of monoclinic WO3 nanoplates and nanorods used as an electrocatalyst for hydrogen evolution reactions from water. Chem. Eng. J. 165, 365-369 (2010).

194. Kim, S., Park, S., Park, S. \& Lee, C. Acetone sensing of Au and Pd-decorated WO3 nanorod sensors. Sens. Actuators B Chem. 209, 180-185 (2015).

195. Labidi, A. et al. Impedance spectroscopy on WO3 gas sensor. Sens. Actuators B Chem. 106, 713718 (2005).

196. Nandi, D. K. \& Sarkar, S. K. Atomic Layer Deposition of Tungsten Oxide for Solar Cell Application. Energy Procedia 54, 782-788 (2014).

197. Malm, J., Sajavaara, T. \& Karppinen, M. Atomic Layer Deposition of WO3 Thin Films using W(CO)6 and 03 Precursors. Chem. Vap. Depos. 18, 245-248 (2012).

198. Jackson, D. H. K., Dunn, B. A., Guan, Y. \& Kuech, T. F. Tungsten hexacarbonyl and hydrogen peroxide as precursors for the growth of tungsten oxide thin films on titania nanoparticles. AIChE J. 60, 1278-1286 (2014). 
199. Mamun, M. A., Zhang, K., Baumgart, H. \& Elmustafa, A. A. Nanomechanical Properties of Tungsten Trioxide (WO3) Grown by Atomic Layer Deposition. ECS Trans. 64, 211-217 (2014).

200. Mamun, M. A., Zhang, K., Baumgart, H. \& Elmustafa, A. A. Nanomechanical and Morphological Characterization of Tungsten Trioxide (WO3) Thin Films Grown by Atomic Layer Deposition. ECS J. Solid State Sci. Technol. 4, P398-P401 (2015).

201. Tägtström, P., Ma\a artensson, P., Jansson, U. \& Carlsson, J.-O. Atomic layer epitaxy of tungsten oxide films using oxyfluorides as metal precursors. J. Electrochem. Soc. 146, 3139-3143 (1999).

202. Strobel, A., Schnabel, H.-D., Reinhold, U., Rauer, S. \& Neidhardt, A. Room temperature plasma enhanced atomic layer deposition for $\mathrm{TiO}_{2}$ and $\mathrm{WO}_{3}$ films. J. Vac. Sci. Technol. Vac. Surf. Films 34, $01 \mathrm{~A} 118$ (2016).

203. Feng, Z. et al. Direct Atomic-Scale Observation of Redox-Induced Cation Dynamics in an OxideSupported Monolayer Catalyst: WO x/ $\alpha-F e 2 O 3$ (0001). J. Am. Chem. Soc. 131, 18200-18201 (2009).

204. Becker, J. S., Suh, S., Wang, S. \& Gordon, R. G. Highly Conformal Thin Films of Tungsten Nitride Prepared by Atomic Layer Deposition from a Novel Precursor. Chem. Mater. 15, 2969-2976 (2003).

205. Zhuiykov, S. et al. Atomic layer deposition-enabled single layer of tungsten trioxide across a large area. Appl. Mater. Today 6, 44-53 (2017).

206. Hai, Z. et al. Photodetector with superior functional capabilities based on monolayer WO 3 developed by atomic layer deposition. Sens. Actuators B Chem. 245, 954-962 (2017).

207. Hai, Z. et al. Wafer-scaled monolayer WO 3 windows ultra-sensitive, extremely-fast and stable UV-A photodetection. Appl. Surf. Sci. 405, 169-177 (2017).

208. Mouat, A. R. et al. Volatile Hexavalent Oxo-amidinate Complexes: Molybdenum and Tungsten Precursors for Atomic Layer Deposition. Chem. Mater. 28, 1907-1919 (2016). 
209. Kostis, I. et al. Deposition of undoped and H doped WOx (x?3) films in a hot-wire atomic layer deposition system without the use of tungsten precursors. Surf. Coat. Technol. 230, 51-58 (2013).

210. Dezelah et al. Atomic Layer Deposition of Tungsten(III) Oxide Thin Films from $\mathrm{W}_{2}\left(\mathrm{NMe}_{2}\right)_{6}$ and Water: Precursor-Based Control of Oxidation State in the Thin Film Material. J. Am. Chem. Soc. 128, 9638-9639 (2006).

211. Wang, L. et al. Ultrathin Oxide Films by Atomic Layer Deposition on Graphene. Nano Lett. 12, 3706-3710 (2012).

212. Aria, A. I. et al. Parameter Space of Atomic Layer Deposition of Ultrathin Oxides on Graphene. ACS Appl. Mater. Interfaces 8, 30564-30575 (2016).

213. Lee, K., Kim, D. H. \& Parsons, G. N. Free-Floating Synthetic Nanosheets by Atomic Layer Deposition. ACS Appl. Mater. Interfaces 6, 10981-10985 (2014).

214. Lee, K., Losego, M. D., Kim, D. H. \& Parsons, G. N. High performance photocatalytic metal oxide synthetic bi-component nanosheets formed by atomic layer deposition. Mater. Horiz. 1, 419 (2014).

215. Zhuiykov, S. et al. Wafer-scale fabrication of conformal atomic-layered TiO 2 by atomic layer deposition using tetrakis (dimethylamino) titanium and $\mathrm{H} 2 \mathrm{O}$ precursors. Mater. Des. 120, 99108 (2017).

216. Edy, R. et al. TiO2 nanosheets synthesized by atomic layer deposition for photocatalysis. Prog. Nat. Sci. Mater. Int. 26, 493-497 (2016).

217. Thin solid films: process and applications. (Transworld Research Network, 2008).

218. Hong, H.-K. et al. Atomic Scale Study on Growth and Heteroepitaxy of ZnO Monolayer on Graphene. Nano Lett. 17, 120-127 (2017).

219. Ferrari, A. C. et al. Science and technology roadmap for graphene, related two-dimensional crystals, and hybrid systems. Nanoscale 7, 4598-4810 (2015). 
220. Werner, F. et al. High-rate atomic layer deposition of Al2O3 for the surface passivation of Si solar cells. Proc. SiliconPV 2011 Conf. 1st Int. Conf. Cryst. Silicon Photovolt. 8, 301-306 (2011).

221. Macco, B., Vos, M. F. J., Thissen, N. F. W., Bol, A. A. \& Kessels, W. M. M. Low-temperature atomic layer deposition of $\mathrm{MoO}_{x}$ for silicon heterojunction solar cells: Low-temperature atomic layer deposition of $\mathrm{MoO}{ }_{x}$ for silicon heterojunction solar cells. Phys. Status Solidi RRL Rapid Res. Lett. 9, 393-396 (2015).

222. Weber Matthieu et al. Novel and Facile Route for the Synthesis of Tunable Boron Nitride Nanotubes Combining Atomic Layer Deposition and Annealing Processes for Water Purification. Adv. Mater. Interfaces 0, 1800056 (2018).

223. Knapas, K. \& Ritala, M. In Situ Studies on Reaction Mechanisms in Atomic Layer Deposition. Crit. Rev. Solid State Mater. Sci. 38, 167-202 (2013).

224. Devloo-Casier, K., Ludwig, K. F., Detavernier, C. \& Dendooven, J. In situ synchrotron based x-ray techniques as monitoring tools for atomic layer deposition. J. Vac. Sci. Technol. A 32, 010801 (2013).

225. Zaera, F. Mechanisms of surface reactions in thin solid film chemical deposition processes. Chem. Vap. Depos. At. Layer Depos. Precursor Des. Appl. 257, 3177-3191 (2013).

226. Kumar, H., Er, D., Dong, L., Li, J. \& Shenoy, V. B. Elastic Deformations in 2D van der waals Heterostructures and their Impact on Optoelectronic Properties: Predictions from a Multiscale Computational Approach. Sci. Rep. 5, 10872 (2015).

227. Bishal, A. K., Sukotjo, C. \& Takoudis, C. G. Room temperature TiO2 atomic layer deposition on collagen membrane from a titanium alkylamide precursor. J. Vac. Sci. Technol. A 35, 01B134 (2016).

228. Finch Dudley S. et al. Biocompatibility of atomic layer-deposited alumina thin films. J. Biomed. Mater. Res. A 87A, 100-106 (2007). 
229. G K Hyde and S D McCullen and S Jeon and S M Stewart and H Jeon and E G Loboa and G N Parsons. Atomic layer deposition and biocompatibility of titanium nitride nano-coatings on cellulose fiber substrates. Biomed. Mater. 4, 025001 (2009). 